\title{
EXPLORING PATTERNS OF PHYTODIVERSITY, ETHNOBOTANY, PLANT GEOGRAPHY AND VEGETATION IN THE MOUNTAINS OF MIANDAM, SWAT, NORTHERN PAKISTAN
}

\author{
BY
}

\section{Naveed Akhtar}

M. Phil.

Born in Swat, Khyber Pakhtunkhwa, Pakistan

A Dissertation Submitted in Partial Fulfillment of the Requirements for the Academic Degree of Doctor of Philosophy (PhD) in the Georg-August-University School of Science (GAUSS) under

Faculty of Biology Program Biodiversity and Ecology Georg-August-University of Göttingen 


\title{
EXPLORING PATTERNS OF PHYTODIVERSITY, ETHNOBOTANY, PLANT GEOGRAPHY AND VEGETATION IN THE MOUNTAINS OF MIANDAM, SWAT, NORTHERN PAKISTAN
}

\author{
Dissertation zur Erlangung des Doktorgrades der \\ Mathematisch-Naturwissenschaftlichen Fakultäten der \\ Georg-August-Universität Göttingen \\ Vorgelegt von \\ M.Phil. \\ Naveed Akhtar \\ aus \\ Swat, Khyber Pakhtunkhwa, Pakistan
}

Göttingen, 2014 
WHEN WE ARE FIVE AND THE APPLES ARE FOUR MY MOTHER SAYS "I DO NOT LIKE APPLES"

DEDICATED

TO

\section{My Mother}


Supervisor: Prof. Dr. Erwin Bergmeier
Albrecht-von-Haller-Institute ofPlant Sciences
Department of Vegetation \& Phytodiversity Analysis
Georg-August-University of Göttingen
Untere Karspüle 2
37073, Göttingen, Germany

Co-supervisor: Prof. Dr. Dirk Hölscher

Department of Tropical Silviculture \& Forest Ecology

Georg-August-University of Göttingen

Büsgenweg 1

37077, Göttingen, Germany 


\section{Table of Contents}

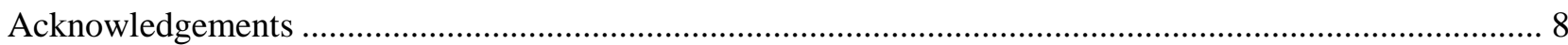

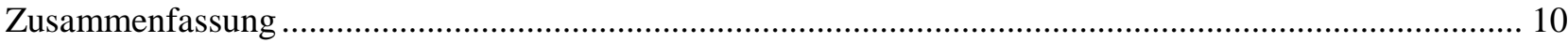

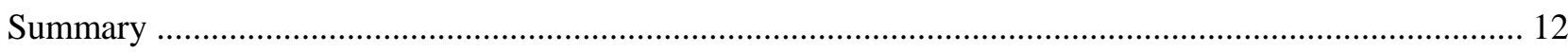

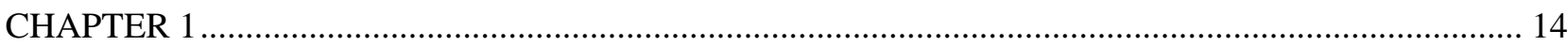

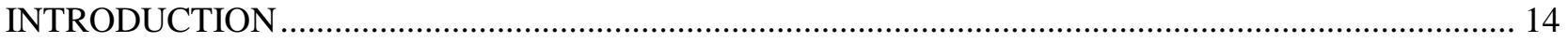

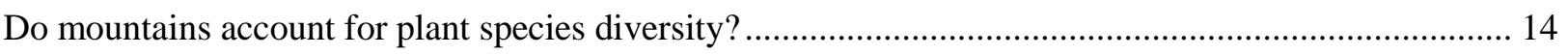

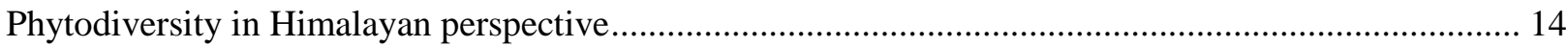

Computer based multivariate analyses of vegetation .......................................................................... 15

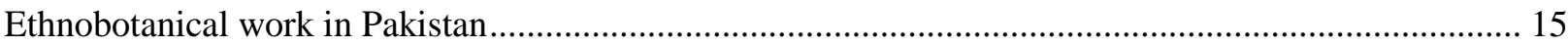

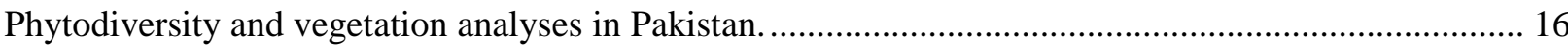

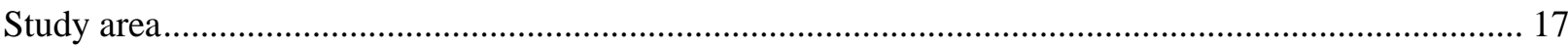

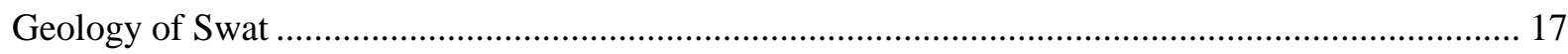

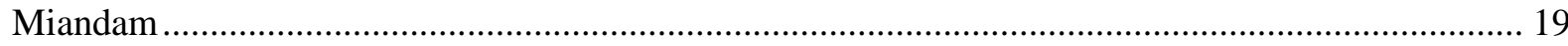

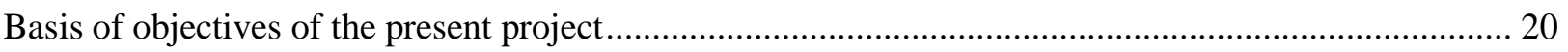

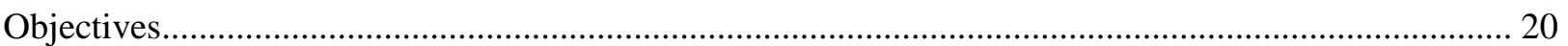

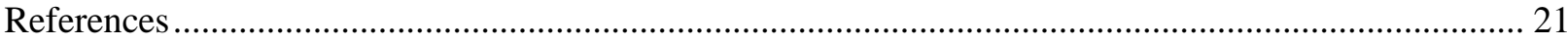

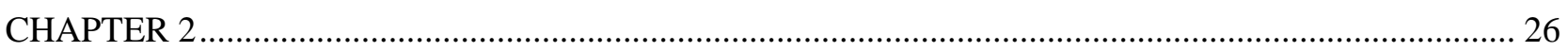

DIVERSITY AND USE OF ETHNO-MEDICINAL PLANTS IN THE REGION OF SWAT, NORTH

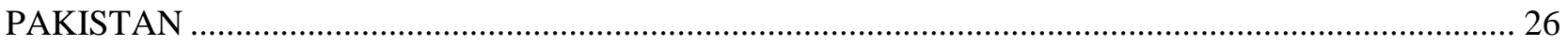

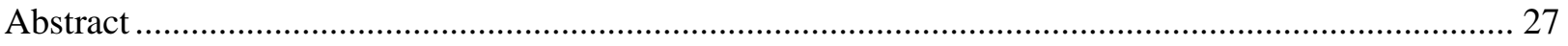

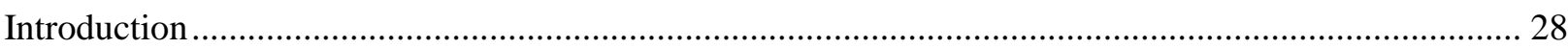

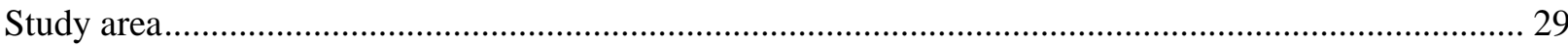

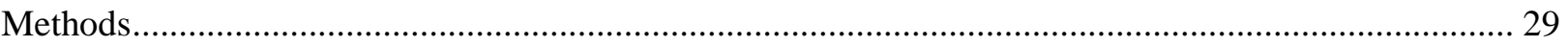

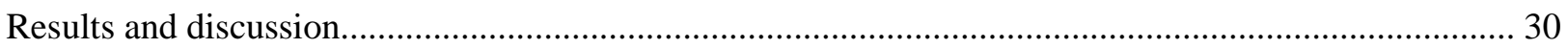

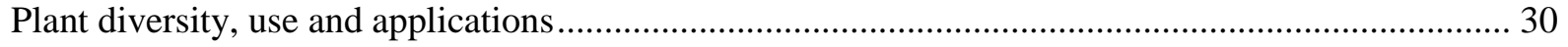

Habitats and conservation of ethno-medicinal plants ....................................................................... 32

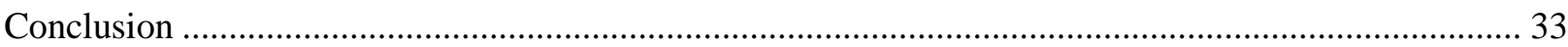

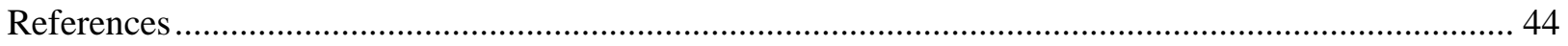


VEGETATION PATTERNS AND HUMAN IMPACT ALONG AN ELEVATION GRADIENT IN THE MOUNTAINS OF SWAT, NORTHERN PAKISTAN

Abstract 50

Introduction 51

Study Area. 52

Materials and methods 53

Data collection 53

Data analysis 54

Results 56

Diversity, classification and description of vegetation 56

(1) Subalpine scrub of Betula utilis 56

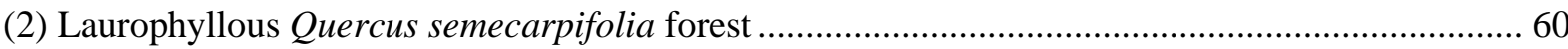

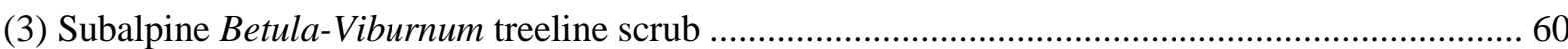

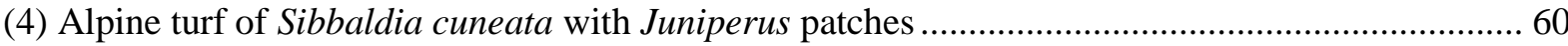

(5) Coniferous forest of Abies pindrow and Geranium wallichianum ............................................. 61

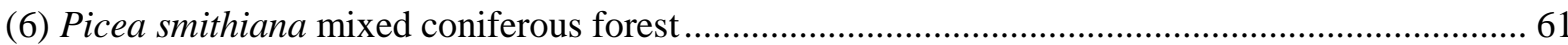

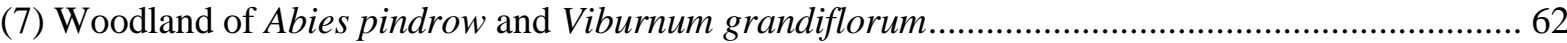

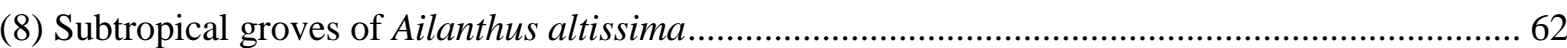

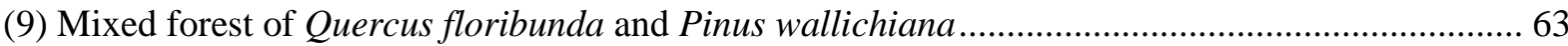

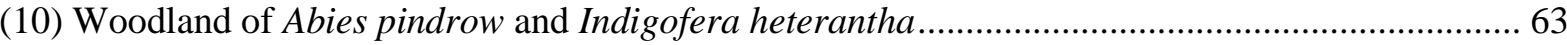

(11) Woodland of Pinus wallichiana with Sorbaria tomentosa shrubbery ......................................... 64

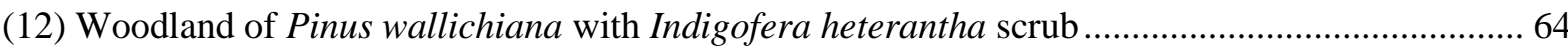

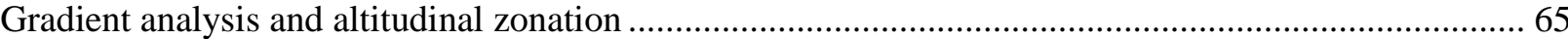

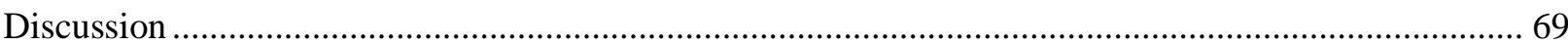

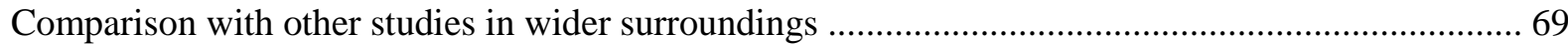

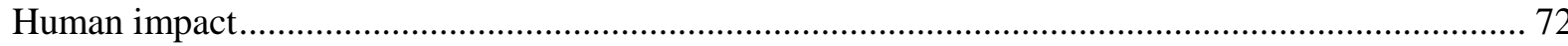

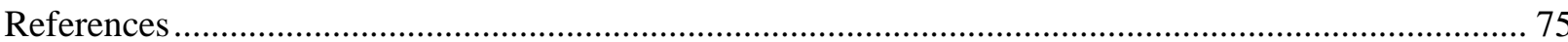


SPECIES RICHNESS, ALPHA AND BETA DIVERSITY OF TREES, SHRUBS AND HERBACEOUS

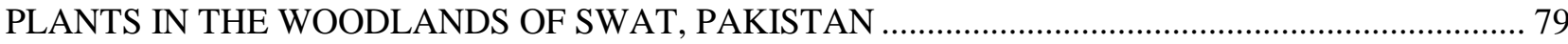

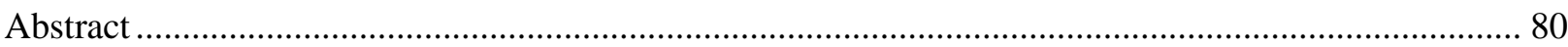

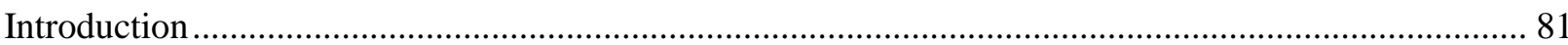

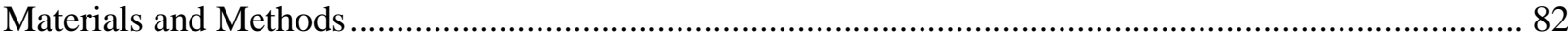

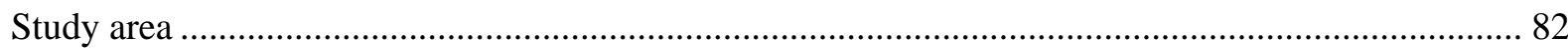

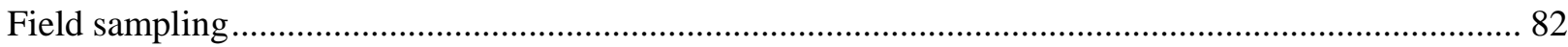

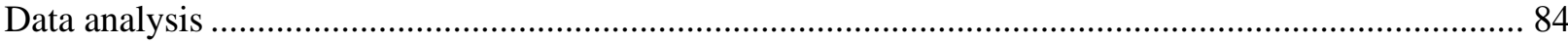

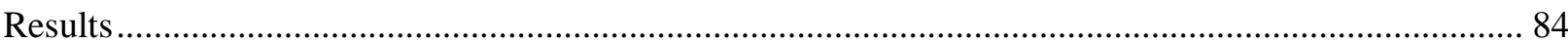

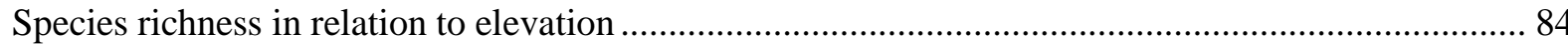

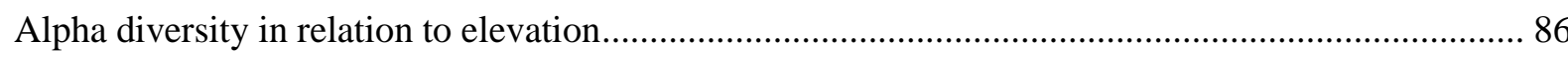

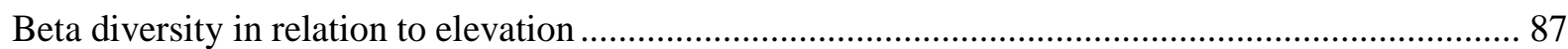

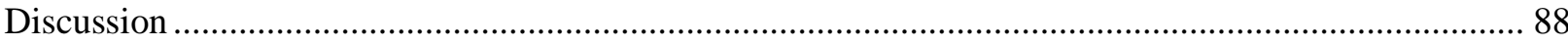

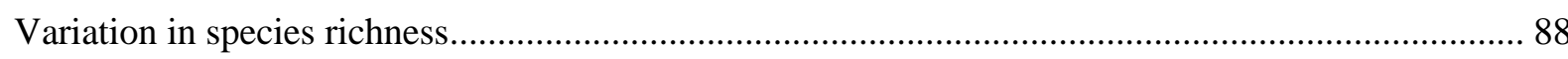

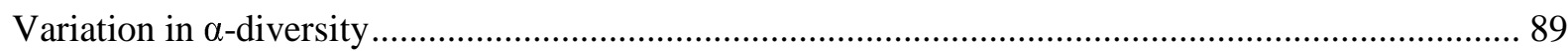

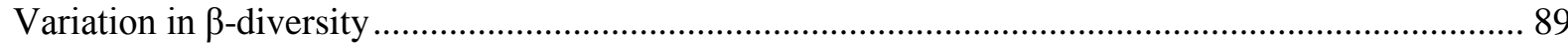

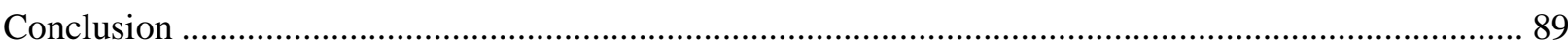

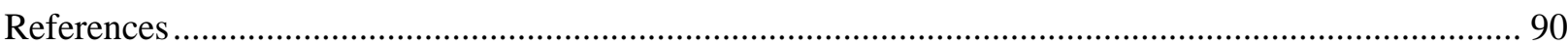

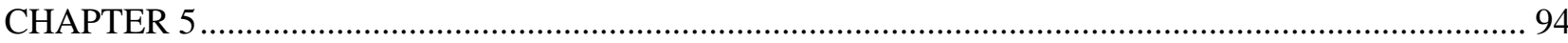

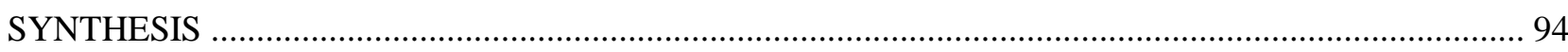

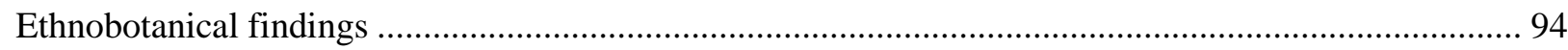

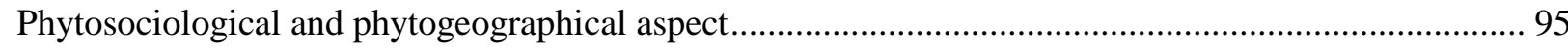

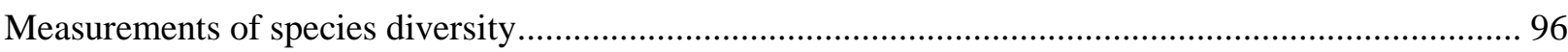

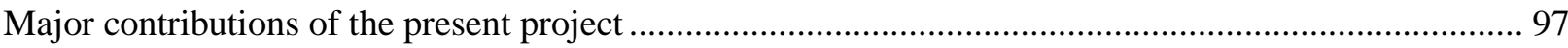

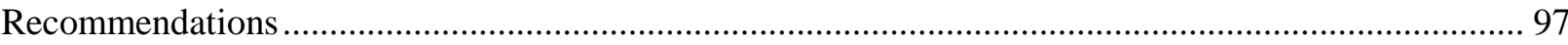

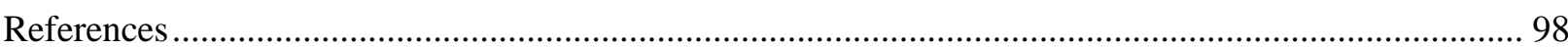

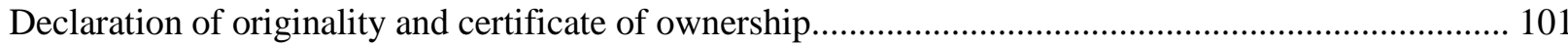




\section{Acknowledgements}

Above all I would like to thank ALLAH Almighty who enabled me to accomplish a job that was difficult for me because of my weakness."He brought me this far and I feel that He is going to help and guide me all the way".

I would like to thank my advisor, Prof. Dr. Erwin Bergmeier who guided me in selecting the theme and area for this research. I would not have been able to do the research and achieve learning without his help and support. His recommendations and instructions have enabled me to assemble and finish the dissertation effectively. During preparation of the manuscripts his criticism and advices were inspiring and fruitful. He encouraged me to not only grow as a vegetation analyst but also as an independent thinker. He also took much care of my social adaptability in an environment which was in the beginning unfamiliar for me.

All my colleagues in the Department Florian Goedecke, Inga Schmiedel, Christian Vogt, Ricarda Pätsch, Charlotte Seifert, Parastoo Mahdavi, Dorothée Wolf, Dr. Victor Chepinoga, Nur Kumalasari, Friedemann Goral and Oliver Fried are highly acknowledged for their academic and moral support from time to time. Office secretaries Ute Wergen and Brigitte Siegesmund were always of unforgettable help whenever I needed any official or technical assistance. Prof. Dr. Hartmut Dierschke and Dr. Heike Culmsee were sources of inspiration for me. I am thankful to Dr. W. Bernhard Dickoré (Botanische Staatssammlung München) and Mr. Klaus Lewejohann (Göttingen) for their help in the identification of plants. Mr. Muhammad Ali (Forschungszentrum Jülich) helped me in GIS programming. Dr. Waheed Murad and Dr. Sajjad Khan were of great help during my stay in Germany. I also acknowledge unforgettable company of Mr. Muhammad Altaf and Mr.Muhammad Haroon and their families. Dr. Jamilurrahman is acknowledged for his support and timely help during compilation of thesis. Company of Mr.Ali Imran and Mr.Niamat khan is indelible. I am thankful to Prof. Dr. Syed Zahir Shah Dean Faculty of Biological Sciences Islamia College University and all other colleagues in the Department of Botany, Islamia College University Peshawar for their services in the Department during my study leave. I express my apology that I could not mention names one by one of all those who helped me in one way or the other. For financial assistance during the course of my doctoral dissertation I highly acknowledge HEC (Higher Education Commission) Pakistan and Islamia College University Peshawar. The Celebrity without whom I would have not materialized my field work is Mr.Zarin Bashar of Miandam. He, his family and many other villagers will always be remembered for their hospitality and company while camping in the hazardous rocky Mountains of Miandam.

I am grateful to a number of people who have guided and supported me not only in the research process but throughout my life. One such personality was my uncle Zahoor Muhammad Khan who left us forever during my study here in Germany. He will always be in our memories. Prayers of my 
mother, brothers and sisters were source of consolation. As I was here in Germany and my family was back home during my last period of $\mathrm{PhD}$, I am highly thankful to my brothers Saeed Akhtar and Junaid Akhtar specially and all other relatives who took much care of my family. I cannot find words to express my gratitude to my daughters and wife whose continued support and encouragement here in Germany and back home paved way to achieve my goals. I would specially mention my wife who proved to be more than a research supervisor who almost every day inquired about progress in my $\mathrm{PhD}$ work. 


\section{Zusammenfassung}

Das Miandam-Untersuchungsgebiet ( $\left.35^{\circ} 1^{\prime}-5^{\prime} \mathrm{N}, 72^{\circ} 30^{\prime}-37^{\prime} \mathrm{E}\right)$ liegt in der Swat-Region der Provinz Khyber Pakhtunkhwa (ehemals North West Frontier Province) im nördlichen Pakistan. Die vorliegende Arbeit berücksichtigt sowohl ethnobotanische und pflanzensoziologische Aspekte als auch die Pflanzenartendiversität innerhalb des Gebietes.

Aufgrund der hohen Habitatvielfalt weist das Miandam-Gebiet einen großen Reichtum von Medizinalpflanzen auf. Die im Rahmen der Arbeit durchgeführte ethnobotanische Studie dokumentiert das Vorkommen der Medizinalpflanzen sowie deren Nutzung in der Region. Weiterhin wurden die durch Sammlerpräferierten Lebensräume bestimmt und evaluiert inwiefern die Heilpflanzen durch Sammlung und Habitatzerstörung bedroht werden. Insgesamt wurden 106 traditionelle Heilpflanzen aus 54 Pflanzenfamilien verzeichnet. $\mathrm{Zu}$ den am häufigsten gefundenen Wuchsformen zählten mehrjährige (43\%) und kurzlebige Kräuter (23\%), Sträucher (16\%) und Bäume (15\%). Ein Großteil der untersuchten Heilpflanzen und ihrer Produkte wird zur Behandlung von Magen-DarmErkrankungen eingesetzt. Die Produkte werden vorrangig als Sud oder Pulver zubereitet und oral angewendet. Achtzig der 106 traditionellen Heilpflanzen gehören der Gruppe der einheimischen Arten an. Fast 50\% der Pflanzenarten treten dabei in synanthroper Vegetation auf, während der Rest in naturnaher Umgebung (z.B. extensiv beweidete Wald- und Graslandbereiche) vorgefunden werden kann. Wälder sind der Ursprung der meisten nicht synanthropen einheimischen Medizinalpflanzen. Drei Arten (Aconitum violaceum, Colchicum luteum, Jasminum humile) können als Folge intensiven Sammelns als bedroht eingestuft werden.

Um die pflanzensoziologischen und phytogeografischen Aspekte des Projektes abzudecken wurde die Vegetation des Miandam-Gebietes mit einem Fokus auf Wäldern, Gebüschen und anderen Formationen untersucht. Die Ergebnisse der Vegetationserhebungen wurden mit denen anderer Studien in der weiteren Umgebung des Hindukush-Himalayas verglichen. Weiterhin wurde untersucht inwiefern die Waldökosysteme durch anthropogene Aktivitäten im Untersuchungsgebiet bedroht sind. Die im Gebiet verzeichneten Gefäßpflanzenarten umfassen insgesamt 33 Bäume, 52 Sträucher, 305 Kräuter und 11 Lianen. Basierend auf einer multivariaten Analyse konnten 12 Pflanzengesellschaften identifiziert werden. Die Spanne dieser Gesellschaften reichte von subtropischen semiariden Wäldern mit Ailanthus altissima im Tiefland zu alpinen Rasen von Sibbaldia cuneata durchsetzt mit Juniperus. Die dominierende Vegetation des Untersuchungsgebietes besteht aus von Abies pindrow und Viburnum grandiflorum Wäldern. Eine georeferenzierte Karte der Vegetation erleichtert die Lokalisierung der ökologisch interessanten Vegetation. 
Artenreichtum und -diversität wurden entlang eines Höhengradienten untersucht. Dazu wurde die Alpha- sowie Beta-Diversität verschiedener Wuchsformtypen bestimmt. Der Artenreichtum aller Gefäßpflanzenarten erreichte sein Maximum zwischen 2200-2500 m. Dagegen zeigte der Artenreichtum der Sträucher einen glockenkurvenartigen Verlauf mit einem Maximum zwischen 2000 und 2200 m. Die höchste Alpha-Diversität der Gefäßpflanzenarten wurde in den tieferen Lagen des Untersuchungsgebietes verzeichnet. Die Beta-Diversität aller Wuchsformtypen zeigte entlang des gesamten Höhengradienten hohe Werte und somit einen starken Artenwechsel. Die Beta-Diversität der Straucharten fluktuiert entlang des Höhengradienten und zeigt damit ein einzigartiges Muster. 


\section{Summary}

The study area of Miandam ( $\left.35^{\circ} 1^{\prime}-5^{\prime} \mathrm{N}, 72^{\circ} 30^{\prime}-37^{\prime} \mathrm{E}\right)$ is located in the District of Swat in the Province of Khyber Pakhtunkhwa (formerly North West Frontier Province) in the North of Pakistan. The present project is a combination of three different studies that consist of ethnobotanical, phytosociological and phytodiversity aspects.

Due to its geographical and habitat conditions, the area of Miandam harbors a wealth of medicinal plants. The ethnobotanical study was carried out to document which medicinal plant species and which plant parts are used in the region. It was also observed which habitat is frequented by collectors and to which extent medicinal plants are vulnerable due to collection and habitat destruction. A total of 106 ethno-medicinal plant species belonging to 54 plant families were recorded. The most common growth forms were perennial (43\%) and short-lived herbs (23\%), shrubs (16\%), and trees (15\%). Most frequently used plant parts were leaves (24\%), fruits (18\%) and subterranean parts (15\%). A considerable proportion of the ethno-medicinal plant species and remedies concerns gastro-intestinal disorders. The remedies were mostly prepared in the form of decoction or powder and were mainly taken orally. Eighty out of 106 ethno-medicinal plants were indigenous. Almost 50\% of the plants occurred in synanthropic vegetation while slightly more than $50 \%$ were found in semi-natural, though extensively grazed, woodland and grassland vegetation. Woodlands are the main source for nonsynanthropic indigenous medicinal plants. Three species (Aconitum violaceum, Colchicum luteum, Jasminum humile) must be considered vulnerable due to excessive collection.

To cover the phytosociological and phytogeographical aspect of the present project, vegetation of Miandam area was thoroughly investigated with particular focus on woodlands, shrublands and other formations. The findings of the vegetation study were compared with other studies in the wider surroundings of Hindukush-Himalaya. It was also assessed to what extant forest ecosystem is threatened by different anthropogenic activities. The vascular plant species found comprise 33 trees, 52 shrubs, 305 herbs and 11 climbers. Based on multivariate analysis twelve plant communities were established from Sub-tropical semiarid groves of Ailanthus altissima in the lowland to Alpine turf of Sibbaldia cuneata with Juniperus patches. Woodland of Abies pindrow and Viburnum grandiflorum is the dominant woodland vegetation in the area. A georeferenced map of the vegetation is presented that will help researchers in spotting vegetation of ecological interest.

Patterns of species richness and diversity were also evaluated along an elevation gradient. Alpha and beta diversities of different growth forms were determined. Species richness of all the vascular plants was highest between 2200-2500 m. A hump shaped relationship was found between shrub richness and elevation with maximum species richness of shrubs between 2000 and $2200 \mathrm{~m}$. For all the 
vascular plants Alpha diversity was high in the lower zone of the elevation gradient. Beta diversity of all the growth forms was quite high along the entire gradient reflecting high species turnover. A unique pattern of beta diversity of shrub species was observed which fluctuated along the elevation gradient giving rise to a unimodal pattern. 


\section{CHAPTER 1}

\section{INTRODUCTION}

\section{Do mountains account for plant species diversity?}

Approximately $25 \%$ of the land surface of the Earth is covered by mountains, which host at least a third of terrestrial plant species diversity (Barthlott, 1996) As one ascends a mountain, environmental conditions change, and one finds organisms that are commonly well adapted to the local conditions along an altitudinal transect, thus offering ideal conditions for exploring evolutionary adaptation over short spatial distances. However, the interpretation of results obtained from such works becomes difficult when the gradients selected include environmental changes that reflect local or regional peculiarities, such as fire (Hemp, 2005),land use (Spehn et al. 2006) or drought (Marshall and Zhang, 1994), not generally associated with altitude above sea level. Since many conspicuous changes of community composition and richness are related to differences in elevation, altitudinal gradients have become increasingly popular for investigating diversity patterns (Grytnes and McCain, 2007; Rahbek, $1995 ; 2005)$. One of the analytical advantages of elevational gradients is that they are replicated across the globe, allowing contrasting gradients under different climatic, edaphic, or topographic situations (Lomolino, 2001; McCain, 2009).The relationship between species richness and elevation is complex, depending on the taxonomic group and the gradient considered, with hump-shaped (Bhattarai et al. 2004; Brehm et al. 2007; Kluge et al. 2006; Oommen and Shanker, 2005) and monotonically decreasing (for e.g.,Patterson et al. 1998) patterns being the most common (Kessler et al. 2009; McCain, 2009; Rahbek, 1995; 2005).

\section{Phytodiversity in Himalayan perspective}

The Himalayas include the highest mountains in the world with the greatest ecological amplitude (Dobremez and Jest, 1976). Himalayan vegetation is diverse and ranges from tropical evergreen species in the south east to thorn steppe and alpine species in the north-western parts (Behera and Kushwaha, 2007). Himalayas affect global climate by bringing changes in temperature and precipitation. Within a relatively short horizontal distance, one can find large environmental variation from humid lowland forests to the glaciated and snowbound upper regions. This mountain range is therefore an excellent place for studying species richness patterns (Körner, 2000) and for testing various biogeographical hypotheses (Carpenter, 2005). Species richness patterns along the Himalayan 
elevational gradient have been analyzed for: flowering plants (Bhattarai and Vetaas, 2003; Carpenter, 2005; Grytnes and Vetaas, 2002; Vetaas and Grytnes, 2002; Wang et al. 2006; 2007), ferns (Bhattarai et al. 2004),liverworts and mosses (Grau et al. 2007), lichens (Baniya et al. 2010) and birds and mammals (Hunter and Yonzon, 1993). In addition to high species richness, the central and eastern Himalaya also supports many endemic plant species (Singh, 2001; Vetaas and Grytnes, 2002). These species have a special value in nature conservation because they are restricted to a small geographical region and are vulnerable to extinction from habitat loss, forest destruction and degradation (Rajbhandari et al. 2000; Winkel, 2006). The identification of elevational zones with high numbers of endemic species is valuable for strategic conservation plans in the light of land-use pressures and climate change (Körner, 2000; Klanderud and Birks, 2003). However, regional patterns in total richness may not correspond to endemic richness (Vetaas and Grytnes, 2002). In the Himalayan region, it is proposed that maximum endemic richness occurs at high elevations (Shrestha and Joshi, 1997), possibly caused by evolutionary drivers such as polyploidy and allopatric speciation by means of isolation mechanisms. Consistent with this, Vetaas and Grytnes(2002) found maximum richness of plant species endemic to Nepal in an elevational zone between 3800 and 4200 m, whereas maximum species richness occurred between 1500 and $2500 \mathrm{~m}$.

\section{Computer based multivariate analyses of vegetation}

There are many advantages in using new approaches in multivariate analyses of data. Ecologists get help from computer based statistical and multivariate analytical programs to discover structure in the data set and to analyze the effects of environmental factors on whole group of species. Now computation is cheap and fast (Diaconis and Efron, 1983). Different softwares developed for vegetation science are used for broad understanding, concepts and methods of descriptive analysis of plant community data. Methods of vegetation science include vegetation sampling, classification, and gradient analysis, and exploration of the relationship of species distributions to their environment. For the analyses of my data I used Turboveg (Hennekens and Schaminée, 2001), JUICE (Tichý, 2002), Canoco (Ter Braak and Šmilauer, 2002), PC-Ord (McCune et al. 2002), R (R Core Team, 2014), Arc GIS (ESRI, 2011) and Excel (Microsoft Word) etc.

\section{Ethnobotanical work in Pakistan}

Ethnobotanical work in Pakistan is not old. But in the last decade the ethnobotanical work has multiplied. Lot of work related to ethnobotany and medicinal plants usage has been carried out in different parts of Pakistan. It includes studies from D.I.Khan (Marwat et al. 2011), Hazar nao, 
Malakand (Murad et al. 2011), Noorpur thal, Khushab (Shaheen et al. 2012b), Gujranwala (Mahmood et al. 2013), Kalat and Khuzdar (Tareen et al. 2010), Hub, Baluchistan (Qasim et al. 2010), Khirthar National Park (Panhwar and Abro, 2007), Nara desert (Qureshi and Raza Bhatti, 2008) and Skardu (Bano et al. 2014). Most of the work is in documentation phase. Universities are involved in research related to ethnobotany. It will provide baseline data but still there is need of phytochemical screening and pharmacological testing. Some research institutes like PCSIR (Pakistan Council of Scientific and Industrial Reserch) and HEJ (Hussain Ebrahim Jamal) Karachi are involved in phytochemical screening and pharmacological research. Some famous industries like Hamdard, Qarshi, are actively involved in the production of plant products. It is now essential to develop a liaison among universities, research organizations and industries.

\section{Phytodiversity and vegetation analyses in Pakistan.}

Phytosociological work in Pakistan has some tradition but is still at the very beginning and both local studies and comprehensive surveys are scarce or missing. Studies such as Chaudhri and Qadir (1958), Qadir et al.(1966), Shaukat and Qadir (1971) and Hussain et al.(1981) represent pioneer works on vegetation analysis but relatively few studies have been added since (recently, e.g., Siddiqui et al.(2010); Shaheen et al.(2012a) Khan et al.(2013). A total of 1,572 genera and 5,521 species of flowering plants have been documented for Pakistan (Ali and Qaiser, 2011), including many endemic plants. To date 5 monotypic genera (Douepia, Sulaimania, Kurramiana, Wendelboa and Spiroseris) and c. 400 species belonging to c. 169 genera and 45 families are endemic in Pakistan. About $80 \%$ of endemic flowering plants are confined to the northern and western mountains of Pakistan (Ali, 2008). Most recently computer based multivariate vegetation analyses have been produced, chiefly thanks to HEC (Higher education commission) initiatives to send Pakistani students and teachers abroad to learn advanced computer skills, or to hire foreign scientists for teaching and research in various universities and research organizations in Pakistan. 


\section{Study area}

\section{Geology of Swat}

The Swat valley and adjoining parts of NW Pakistan consist of rock units representing the Kohistan Arc sequence. The Kohistan arc terrane in north Pakistan is widely regarded as one of the most completely exposed sections from the deep root to the volcanic edifice of an island arc (Searle et al. 1999). The Kohistan arc sequence constitutes the hanging wall of the main mantle thrust and essentially consists of late Jurassic-Cretaceous and Tertiary plutonic, meta-plutonic, meta-volcanic, and meta sedimentary rocks (Figure 2). From south to north, the Kohistan Arc sequence consists of the (i) Jijal Complex, (ii) Kamila Amphibolites, (iii) Chilas Complex, (iv) Kohistan Batholith and Gilgit gneisses, (v) Chalt-Ghizar, Sharman and Utror volcanics and (vi) Yasin metasediments. The ultramafic-mafic Jijal Complex represents the upper mantle to lower crust transition (Arif et al. 2011).

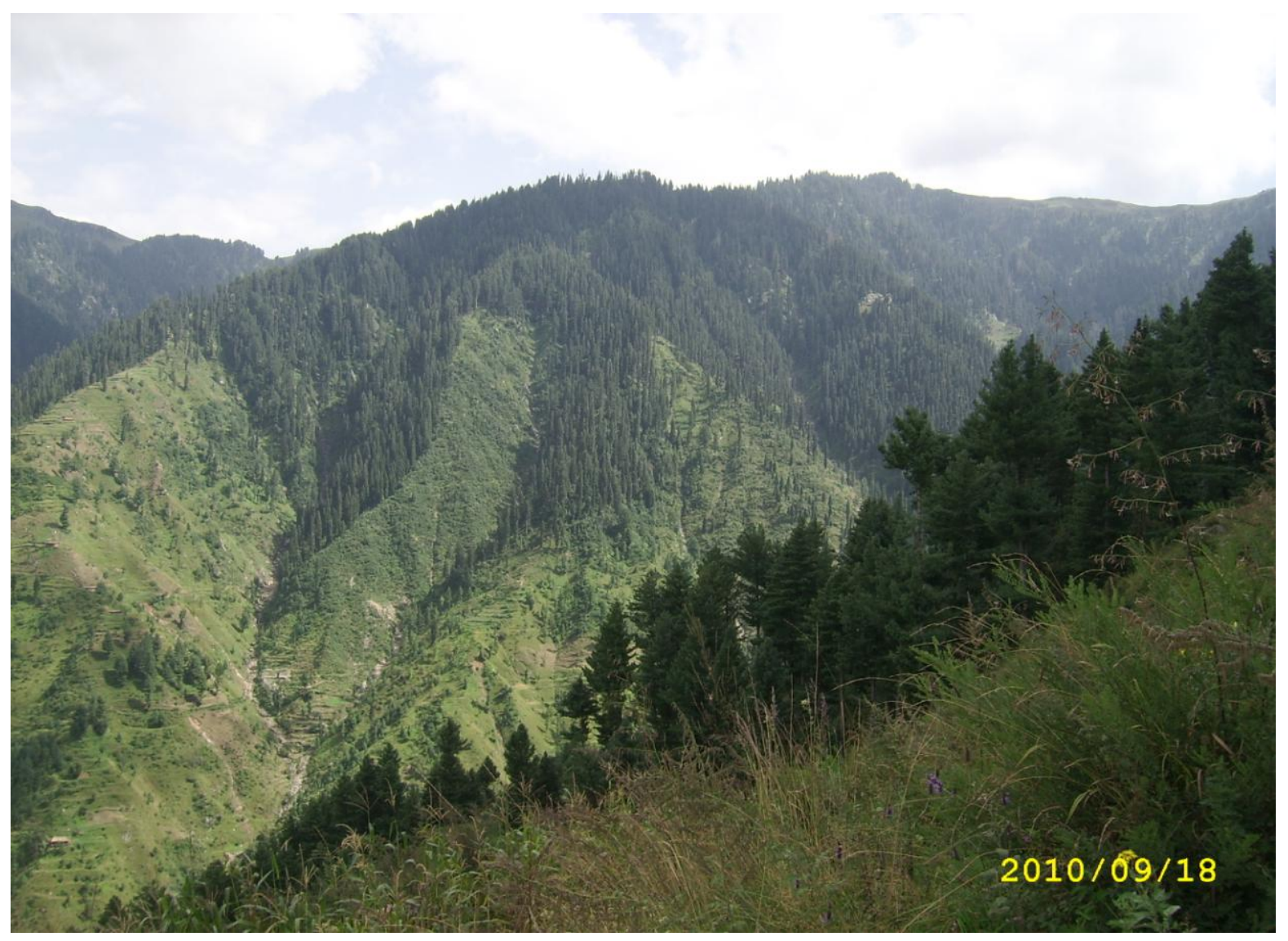

Figure 1.Miandam Mountains though looking lush green but affected by logging and habitat deterioration. 


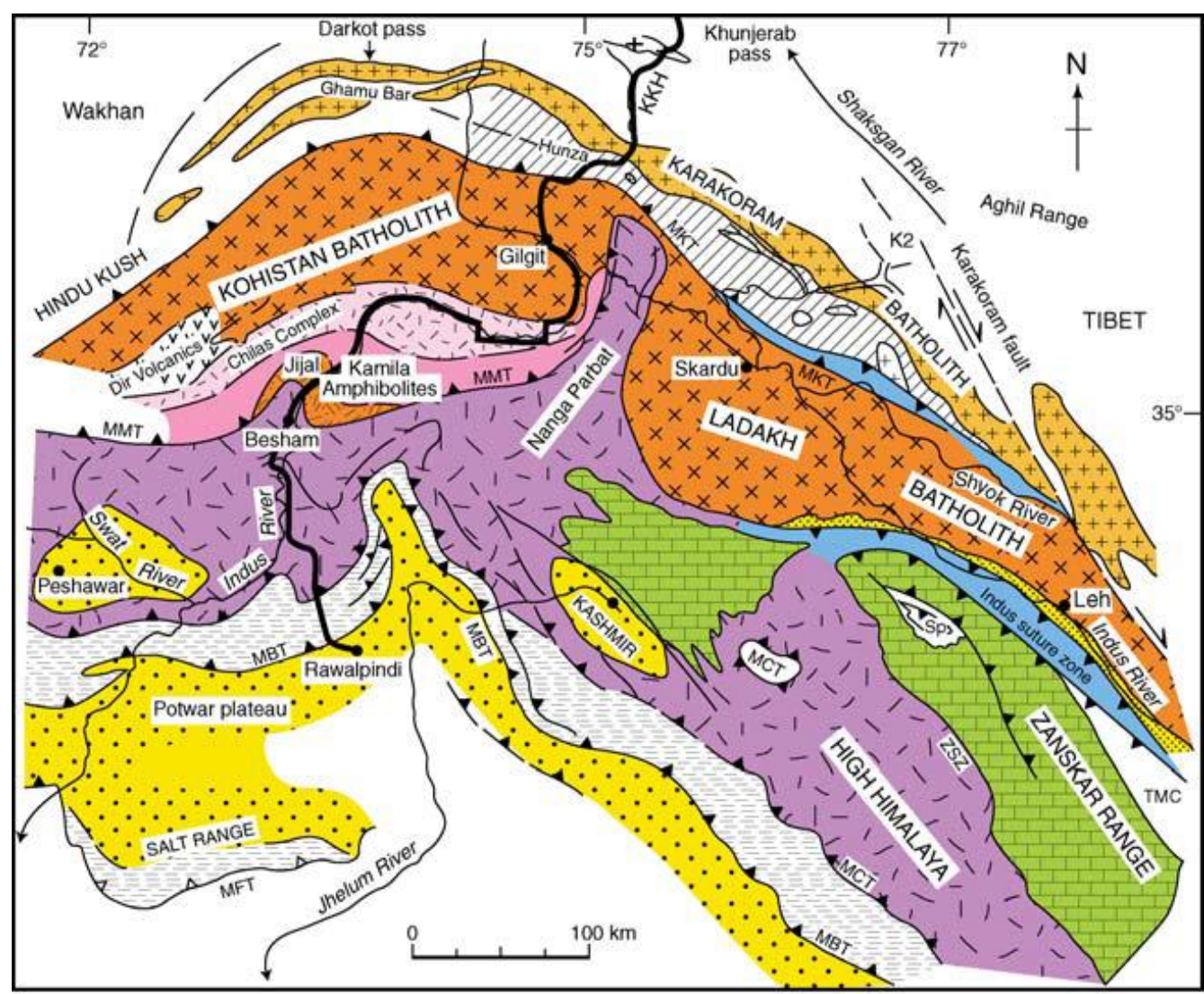

ASIAN PLATE

INDIAN PLATE
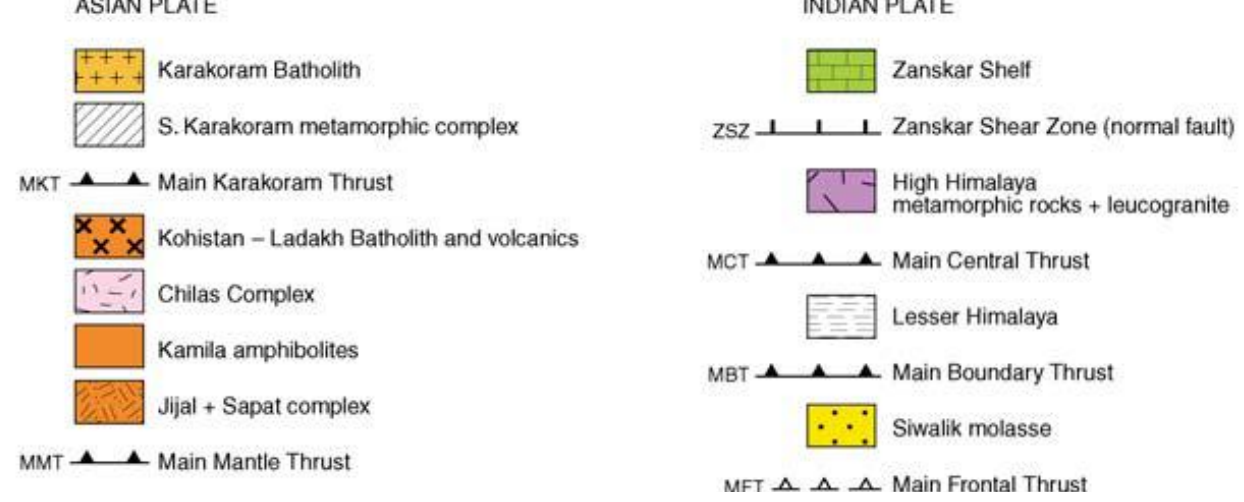

Figure 2. Geological map of the western Himalaya, Kohistan and Karakorum (after Searle et al. 1999). 


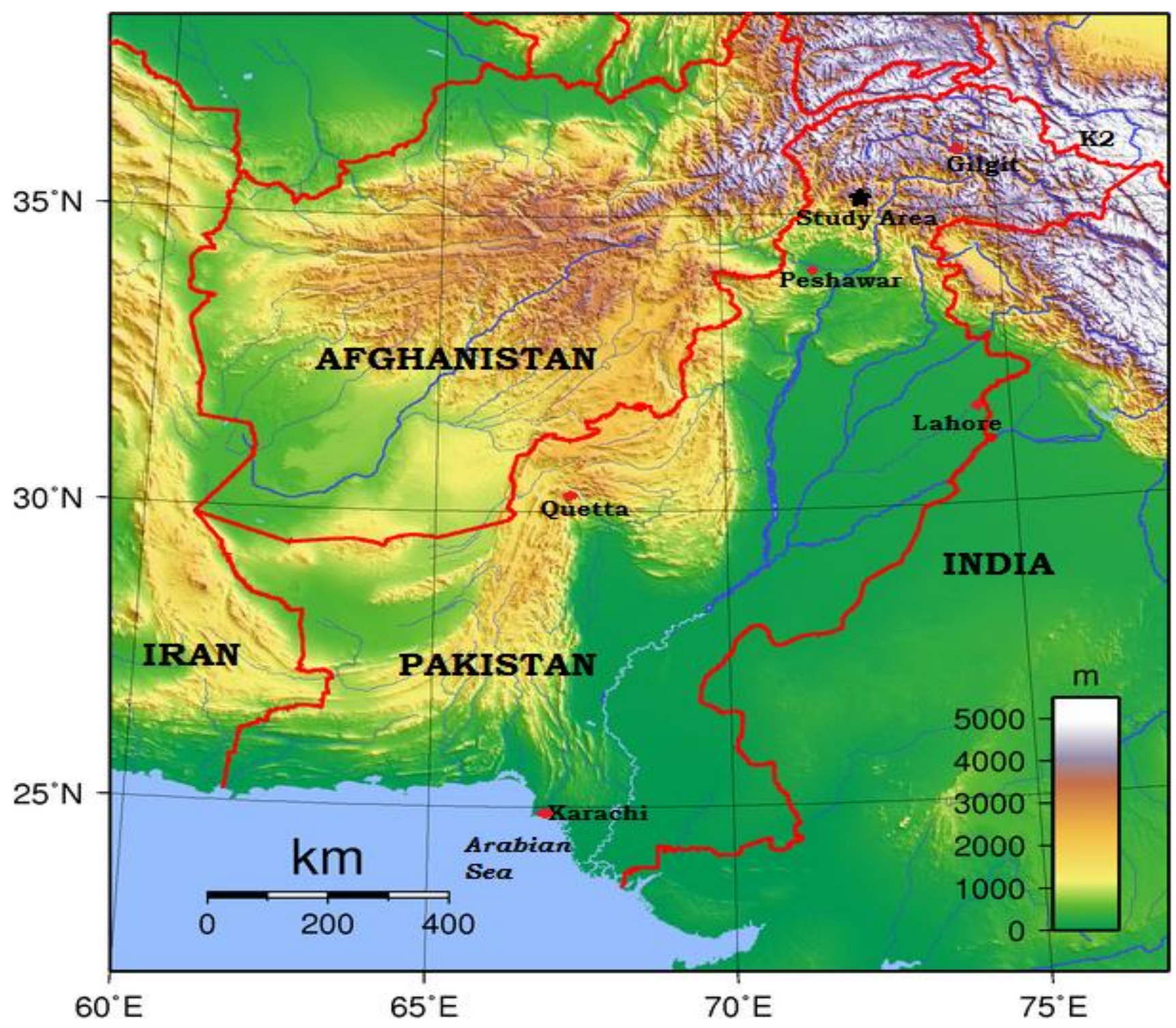

Figure 3. Topographic map of Pakistan showing location of the study area between Gilgit and Peshawar, (Sadalmelik, 2007).

\section{Miandam}

The study area (Figure 1) of Miandam $\left(35^{\circ} 4^{\prime} \mathrm{N}, 72^{\circ} 29-32^{\prime} \mathrm{E}\right)$ is located in the District of Swat in the Province of Khyber Pakhtunkhwa (formerly North West Frontier Province). The province is located on both banks of the river Indus and is bounded by the Himalaya, Karakoram and Hindukush Mountains in the north and Afghanistan in the north-west. The District of Swat is located in the north of Khyber Pakhtunkhwa. Miandam lies about $50 \mathrm{~km}$ northeast of Saidu Sharif, district capital of Swat, and $21 \mathrm{~km}$ from Khwazakhela, administrative centre of the surrounding villages. Its western boundary is the river Swat. A topographic map of Pakistan showing the study area is presented in Figure 3. 


\section{Basis of objectives of the present project}

Plant collections in the Indian sub-continent started as early as $1820-1822$ by W. Moorcroft who collected in Ladakh and Kashmir, followed by V. Jacquemont in 1828-1832 in Punjab and Kashmir. J. F. Royle (1832-1834) also collected in Kashmir. N. Vicary was the first to collect in Sindh in 1838; he also collected in Salt Range, Punjab and the Khyber Pakhtunkhwa region. William Griffith was the first collector in Baluchistan and Khyber Pass area in 1838.R.R.Stewart (1890-1993) collected plants from all over Pakistan (Ali, 2008).

Ecosystems in high mountain regions are intricate and significant. Cost and time factors are involved in their study, particularly where they are remote. Conserving plant biodiversity requires consistent and sound qualitative as well as quantitative records of botanical data on a regular basis (Clubbe et al. 2010) and subtle phytosociological and other ecological sampling techniques are essential to achieve this. Ethnobotanical methods can be linked to this, to describe and evaluate the nature and value of the ecosystem services that plant communities provide for local people. Data obtained through a combination of these techniques provides basic knowledge for conservation managers and biodiversity planners to evaluate the services provided by mountain ecosystems and to formulate sustainable management. Surveying the enormous diversity of the world's vegetation is one of the basic tasks of vegetation science. In recent decades the demand for vegetation survey data has been steadily increasing particularly in applied fields such as biodiversity conservation and environmental monitoring. Vegetation survey and classification are also very important in basic ecological and biodiversity research. Interpretations of biodiversity patterns and their underlying mechanisms strongly depend on the definitions and delimitations of the studied systems. In this context, survey and classification provide essential tools for defining vegetation or ecosystem types and a framework for understanding differences among them (Chytrý et al. 2011)

Keeping in view the above aspects of biodiversity research the present project was initiated in the mountains of the region of Miandam, Swat, Northern Pakistan, to achieve the objectives outlined below.

\section{Objectives}

The objectives of the dissertation project are described in the context of the three result chapters. Chapter (2) deals with traditional knowledge about plants, an important asset for the people of the area. This knowledge passes from generation to generation and can be lost if not documented. One of the objectives was to document the empirical knowledge about medicinal plants of the area. The aim 
was to gather and document baseline information regarding medicinal plants that can be further used for future phytochemical and pharmacological studies. Moreover, the target was to classify medicinal plants according to biological and distributional properties as well as ecological preference. It was also focused that where and in which habitat ethno-medicinal plants occur; as such knowledge is a prerequisite to identify vulnerable plant species susceptible to collecting or habitat change.

In chapter (3), among other objectives one aim was to survey woodlands, shrublands and other widespread formations in the research area to describe the vegetation zones along elevation. Our next objective was revealing similarities and dissimilarities of plant communities with plant communities described in literature from the wider area of Hidukush-Himalaya. With logging and grazing occurring largely uncontrolled, a focus was on human impact, to provide a risk assessment for the plant communities in the forest ecosystem. Quantitative analysis of vegetation of the study area was also planned and achieved by combining multivariate classification and ordination techniques.

Chapter (4) deals with the study of variation in species richness and diversity along elevation in the region. As patterns of diversity on different mountains are different, species richness and diversity of different growth forms were statistically determined along elevation gradient based on regression modeling. The focus was on the following two research questions: (1) Do species richness and diversity vary among different growth forms along the elevation gradient studied? (2) Are variations along the elevation gradient monotonic, unimodal, or otherwise? To my knowledge this is the first study for Pakistan Himalaya in which the diversity patterns of different growth forms of plants have been tested along an elevation gradient.

\section{References}

Ali,H., Qaiser,M., 2011. Contribution to the Red List of Pakistan: a case study of the narrow endemic Silene longisepala (Caryophyllaceae). Oryx 45, 522-527.

Ali,S.I., 2008. Significance of Flora with special reference to Pakistan. Pak. J. Bot 40, 967-971.

Arif,M., Henry,D.J., Moon,C.J., 2011. Host rock characteristics and source of chromium and beryllium for emerald mineralization in the ophiolitic rocks of the Indus Suture Zone in Swat, NW Pakistan. Ore Geology Reviews 39, 1-20.

Baniya,C.B., Solhoy,T., Gauslaa,Y., Palmer,M.W., 2010. The elevation gradient of lichen species richness in Nepal. The Lichenologist 42, 83-96.

Bano,A., Ahmad,M., Hadda,T.B., Saboor,A., Sultana,S., Zafar,M., Khan,M.P., Arshad,M., Ashraf,M.A., 2014. Quantitative ethnomedicinal study of plants used in the skardu valley at high altitude of karakoram-himalayan range, Pakistan. Journal of Ethnobiology and Ethnomedicine 10, 43. 
Barthlott,W., 1996. Global distribution of species diversity in vascular plants: towards a world map of phytodiversity. Erdkunde 50, 317-327.

Behera,M.D., Kushwaha,S.P.S., 2007. An analysis of altitudinal behavior of tree species in Subansiri district, Eastern Himalaya. Plant Conservation and Biodiversity 277-291.

Bhattarai,K.R., Vetaas,O.R., 2003. Variation in plant species richness of different life forms along a subtropical elevation gradient in the Himalayas, east Nepal. Global Ecology and Biogeography 12, 327-340.

Bhattarai,K.R., Vetaas,O.R., Grytnes,J.A., 2004. Fern species richness along a central Himalayan elevational gradient, Nepal. Journal of Biogeography 31, 389-400.

Brehm,G., Colwell,R.K., Kluge,J., 2007. The role of environment and mid-domain effect on moth species richness along a tropical elevational gradient. Global Ecology and Biogeography 16, 205-219.

Carpenter,C., 2005. The environmental control of plant species density on a Himalayan elevation gradient. Journal of Biogeography 32, 999-1018.

Chaudhri,I.I., Qadir,S.A., 1958. Sand dunes vegetation of coastal regions of Karachi. Pak. J. For 8, 337-341.

Chytrý,M., Schaminée,J.H., Schwabe,A., 2011. Vegetation survey: a new focus for Applied Vegetation Science. Applied Vegetation Science 14, 435-439.

Clubbe,C., Hamilton,M., Corcoran,M., 2010. Using the Global Strategy for Plant Conservation to guide conservation implementation in the UK Overseas Territories. Kew Bulletin 65, 509-517.

Diaconis,P., Efron,B., 1983. Computer-intensive methods in statistics. Scientific American 248, 116130.

Dobremez, Jean François and Jest, Corneille.1976. Manaslu: hommes et milieux des vallées du Népal central. Éditions du Centre national de la recherche scientifique.

ESRI,A.D., 2011. Release 10. Documentation Manual. Redlands, CA, Environmental Systems Research Institute,California, USA.

Grau,O., Grytnes,J.-A., Birks,H.J.B., 2007. A comparison of altitudinal species richness patterns of bryophytes with other plant groups in Nepal, Central Himalaya. Journal of Biogeography 34, 19071915.

Grytnes, John Arvid and McCain, Christy M.2007. Elevational trends in biodiversity. Elsevier Inc.

Grytnes,J.A., Vetaas,O.R., 2002. Species richness and altitude: a comparison between null models and interpolated plant species richness along the Himalayan altitudinal gradient, Nepal. The American Naturalist 159, 294-304.

Hemp,A., 2005. Climate change-driven forest fires marginalize the impact of ice cap wasting on Kilimanjaro. Global Change Biology 11, 1013-1023.

Hennekens,S.M., Schaminée,J.H.J., 2001. TURBOVEG, a comprehensive data base management system for vegetation data. Journal of Vegetation Science 12 (4), 589-591. 
Hunter,M.L., Yonzon,P., 1993. Altitudinal distributions of birds, mammals, people, forests, and parks in Nepal. Conservation Biology 420-423.

Hussain,F., Haq,I., Naqvi,H.H., 1981. Phytosociological studies on some saline areas of Peshawar Valley. J. Sci. \& Tech 5, 65-68.

Kessler,M., Krömer,T., Kluge,J., Karger,D.N., Acebey,A., Hemp,A., Herzog,S.K., Lehnert,M., 2009. Elevational gradients of species richness derived from local field surveys versus'mining' of archive data. Data mining for global trends in mountain biodiversity 57-63.

Khan,S.M., Page,S., Ahmad,H., Harper,D., 2013. Identifying plant species and communities across environmental gradients in the Western Himalayas: Method development and conservation use. Ecological Informatics 14, 99-103.

Klanderud,K., Birks,H.J.B., 2003. Recent increases in species richness and shifts in altitudinal distributions of Norwegian mountain plants. The Holocene 13, 1-6.

Kluge,J., Kessler,M., Dunn,R.R., 2006. What drives elevational patterns of diversity? A test of geometric constraints, climate and species pool effects for pteridophytes on an elevational gradient in Costa Rica. Global Ecology and Biogeography 15, 358-371.

Körner,C., 2000. Why are there global gradients in species richness? mountains might hold the answer. Trends in Ecology \& Evolution 15, 513-514.

Lomolino,M.V., 2001. Elevation gradients of species-density: historical and prospective views. Global Ecology and Biogeography 10, 3-13.

Mahmood,A., Mahmood,A., Malik,R.N., Shinwari,Z.K., 2013. Indigenous knowledge of medicinal plants from Gujranwala district, Pakistan. Journal of ethnopharmacology 148, 714-723.

Marshall,J.D., Zhang,J., 1994. Carbon Isotope Discrimination and Water-Use Efficiency in Native Plants of the North-Central Rockies. Ecology 75, 1887-1895.

Marwat,S.K., Mir Ajab Khan, Fazalurrahman, Ahmad,M., Zafar,M., GHULAM,S., 2011. Medicinal folk recipes used as traditional phytotherapies in district Dera Ismail Khan, KPK, Pakistan. Pak. J. Bot 43, 1453-1462.

McCain,C.M., 2009. Global analysis of bird elevational diversity. Global Ecology and Biogeography $18,346-360$.

McCune, Bruce, Grace, James B., and Urban, Dean L.2002. Analysis of ecological communities. MjM software design Gleneden Beach, OR.

Murad,W., Ahmad,A., Gilani,S.A., Khan,M.A., 2011. Indigenous knowledge and folk use of medicinal plants by the tribal communities of Hazar Nao Forest, Malakand District, North Pakistan. Journal of medicinal plants research 5, 1072-1086.

Oommen,M.A., Shanker,K., 2005. Elevational species richness patterns emerge from multiple local mechanisms in Himalayan woody plants. Ecology 86, 3039-3047.

Panhwar,A.Q., Abro,H., 2007. Ethnobotanical studies of Mahal Kohistan (Khirthar National Park). Pak. J. Bot 39, 2301-2315. 
Patterson,B.D., Stotz,D.F., Solari,S., Fitzpatrick,J.W., Pacheco,V., 1998. Contrasting patterns of elevational zonation for birds and mammals in the Andes of southeastern Peru. Journal of Biogeography 25, 593-607.

Qadir,S.A., Qureshi,S.Z., Ahmed,M.A., 1966. A phytosociological survey of the Karachi University Campus. Vegetatio 13, 339-362.

Qasim,M., Gulzar,S., Shinwari,Z.K., Aziz,I.R.F.A., Khan,M.A., 2010. Traditional ethnobotanical uses of halophytes from Hub, Balochistan. Pak. J. Bot 42, 1543-1551.

Qureshi,R., Raza Bhatti,G., 2008. Ethnobotany of plants used by the Thari people of Nara Desert, Pakistan. Fitoterapia 79, 468-473.

R Core Team, 2014. R: A language and environment for statistical computing. $\mathrm{R}$ foundation for Statistical Computing.

Rahbek,C., 1995. The Elevational Gradient of Species Richness - A Uniform Pattern. Ecography 18, 200-205.

Rahbek,C., 2005. The role of spatial scale and the perception of large-scale species-richness patterns. Ecology Letters 8, 224-239.

Rajbhandari,K.R.,Bhattarai,S.,Joshi,R.,Bista,M.S.,Joshi,R.B.,Amatya,S.M.,Parajuli,A.V.,Adhikari,M. K.,Saiju,H.K.,Thakur,R., Orchid diversity of Nepal and their conservation need. Bio-technology applications for reforestation and biodiversity conservation.Proceedings of the 8th International Workshop of BIO-REFOR, Kathmandu, Nepal, November 28-December 2, 1999. 249-252. 2000. BIO-REFOR, Ministry of Forests and Soil Conservation.

Sadalmelik, Topographic map of Pakistan. Wikimedia under GNU Free Documentation License . 2007.

Searle,M.P., Khan,M.A., Fraser,J.E., Gough,S.J., Jan,M.Q., 1999. The tectonic evolution of the Kohistan-Karakoram collision belt along the Karakoram Highway transect, north Pakistan. Tectonics 18, 929-949.

Shaheen,H., Ullah,Z., Khan,S.M., Harper,D.M., 2012a. Species composition and community structure of western Himalayan moist temperate forests in Kashmir. Forest Ecology and Management 278, 138145 .

Shaheen,H., Qureshi,R., Akram,A., Gulfraz,M., 2012b. Some important medicinal flora of Noorpur Thal, Khushab, Pakistan. Archives Des Sciences 65, 57-73.

Shaukat,S.S., Qadir,S.A., 1971. Multivariate analysis of the vegetation of calcarious hills around Karachi. Vegetatio 23, 235-253.

Shrestha, S. and Joshi, S.1997. Rare, Endemic and Endangered Plants of Nepal. State Mutual Book \& Periodical Service, Limited.

Siddiqui,M.F., Ahmed,M., Shaukat,S.S., Khan,N., 2010. Advanced multivariate techniques to investigate vegetation-environmental complex of Pine forests of moist temperate areas of Pakistan. Pakistan Journal of Botany, Special issue 42, 267-293. 
Singh,S.P., 2001. Central Himalaya biodiversity, ecosystem,characters and conservational approach. Environment and agriculture: biodiversity, agriculture and pollution in South Asia. In: Baral,S.R., Jha,P.K., Karmacharya,S.B., Lekhak,H.D., Lacoul,P., Baniya,C.B. (Eds.), Ecological Society, Kathmandu, Nepal., pp. 15-18.

Spehn, Eva M., Liberman, M., and Korner, Christian.2006. Land use change and mountain biodiversity. CRC Press.

Tareen,R.B., Bibi,T., Khan,M.A., Ahmad,M., Zafar,M., 2010. Indigenous knowledge of folk medicine by the women of Kalat and Khuzdar regions of Balochistan, Pakistan. Pak J Bot 42, 1465-1485.

Ter Braak,C.J.F., Šmilauer,P., 2002. CANOCO reference manual and user's guide to Canoco for Windows: software for canonical community ordination (version 4.5). Microcomputer Power, Ithaca, New York, USA.

Tichý,L., 2002. JUICE, software for vegetaion classification. Journal of Vegetation Science 13 (3), 451-453.

Vetaas,O.R., Grytnes,J.-A., 2002. Distribution of vascular plant species richness and endemic richness along the Himalayan elevation gradient in Nepal. Global Ecology and Biogeography 11, 291-301.

Wang,W., Wang,Q., Li,S., Wang,G., 2006. Distribution and Species Diversity of Plant Communities along Transect on the Northeastern Tibetan Plateau. Biodiversity \& Conservation 15, 1811-1828.

Wang,Z., Tang,Z., Fang,J., 2007. Altitudinal patterns of seed plant richness in the Gaoligong Mountains, south-east Tibet, China. Diversity and Distributions 13, 845-854.

Winkel,G.V., 2006. Finding orchids in Nepal. The Orchid Review 114, 188-191. 


\title{
CHAPTER 2
}

\section{DIVERSITY AND USE OF ETHNO-MEDICINAL PLANTS IN THE REGION OF SWAT, NORTH PAKISTAN}

\author{
Naveed Akhtar ${ }^{1,2}$, Abdur Rashid ${ }^{3}$, Waheed Murad ${ }^{4}$, Erwin Bergmeier ${ }^{2 *}$ \\ ${ }^{1}$ Department of Botany, Islamia College University, Peshawar, 25000, Pakistan \\ ${ }^{2}$ Department of Vegetation Analysis and Phytodiversity, Albrecht von Haller Institute of Plant Sciences, Georg August \\ University, 37073 Göttingen, Germany \\ ${ }^{3}$ Centre of Plant Diversity, University of Peshawar, Peshawar, 25000, Pakistan \\ ${ }^{4}$ Department of Botany, Kohat University of Science and Technology, Kohat, 26000. Pakistan \\ *Corresponding author: erwin.bergmeier@bio.uni-goettingen.de
}

Published in: Journal of Ethnobiology and Ethnomedicine 2013, 9:25

doi :10.1186/1746-4269-9-25 


\begin{abstract}
Background: Due to its diverse geographical and habitat conditions, northern Pakistan harbors a wealth of medicinal plants. The plants and their traditional use are part of the natural and cultural heritage of the region. This study was carried out to document which medicinal plant species and which plant parts are used in the region of Swat, which syndrome categories are particularly concerned, and which habitat spectrum is frequented by collectors. Finally, we assessed to which extent medicinal plants are vulnerable due to collection and habitat destruction.
\end{abstract}

Methods: An ethnobotanical survey was undertaken in the Miandam area of Swat, North Pakistan. Data were collected through field assessment as well as from traditional healers and locals by means of personal interviews and semi-structured questionnaires.

Results: A total of 106 ethno-medicinal plant species belonging to 54 plant families were recorded. The most common growth forms were perennial (43\%) and short-lived herbs (23\%), shrubs (16\%), and trees (15\%). Most frequently used plant parts were leaves (24\%), fruits (18\%) and subterranean parts (15\%). A considerable proportion of the ethno-medicinal plant species and remedies concerns gastro-intestinal disorders. The remedies were mostly prepared in the form of decoction or powder and were mainly taken orally. Eighty out of 106 ethno-medicinal plants were indigenous. Almost 50\% of the plants occurred in synanthropic vegetation while slightly more than $50 \%$ were found in seminatural, though extensively grazed, woodland and grassland vegetation. Three species (Aconitum violaceum, Colchicum luteum, Jasminum humile) must be considered vulnerable due to excessive collection. Woodlands are the main source for non-synanthropic indigenous medicinal plants. The latter include many range-restricted taxa and plants of which rhizomes and other subterranean parts are dug out for further processing as medicine.

Conclusion: Medicinal plants are still widely used for treatment in the area of Swat. Some species of woodlands seem to be adapted to wood-pasture, but vulnerable to overcollecting, and in particular to deforestation. It is suggested to implement local small-scaled agroforestry systems to cultivate vulnerable and commercially valuable ethno-medicinal woodland plants under local self-government responsibility.

Keywords: Ecosystem services, Ethnobotany, Medicinal plants, Miandam, Phytomedicine, Plant applications, Plant conservation, Vernacular plant names 


\section{Introduction}

Plants are an important source of traditional medicine for the treatment of various diseases (Bako et al. 2005). It has been estimated that herbal medicines are used by more than $80 \%$ of the world's population in developing countries to meet their primary healthcare needs (World Health Organization, 2002). In Pakistan, the available modern healthcare services are either insufficient or inaccessible and unaffordable to the majority of people. In addition, due to illiteracy and poverty most of the population is dependent on traditional phytomedicine to cure various ailments. As the country has diverse socio-economic, ethnic, linguistic and cultural areas, as well as unique biodiversity, copious knowledge of indigenous medicinal plants and their use in treating human ailments might reasonably be expected. More than $10 \%$ of the national flora of Pakistan (600-700 plant species) are used for medicinal purposes (Shinwari, 2010). Phytomedicinal research in Pakistan is a recent activity and the documentation of ethnomedicinal plant knowledge and its applications are ongoing (Shinwari, 2010; Abbasi et al. 2011; Sher et al. 2011; Shinwari et al. 2006). The loss of precious medicinal plant wealth due to overgrazing, agricultural expansion, environmental degradation, acculturation and deforestation, enhanced by population pressure and poverty, has been reported by various researchers (Shinwari, 2010; Hussain et al. 2007; Ibrar et al. 2007; Khan and Khatoon, 2008; Sher and Hussain, 2007) but information on which medicinal plant species in particular are vulnerable, and why, is lacking.

Traditional resources of medicinal plants from Chitral, North Pakistan, have been evaluated (Hussain et al. 2007; Ali and Qaiser, 2009). Several studies exist on the ethnomedicinal use of plants in different regions of Swat, North Pakistan (Ibrar et al. 2007; Hamayun et al. 2006; Hussain et al. 2005; Sher and Hussain, 2009; Shinwari and Gilani, 2003). In an ethno-medicinal study from the valley of Miandam, Swat, a total of 179 plant species have been listed (Adnan et al. 2006), with medicinal use reported for 27 plants, but without reference to local names, habitats, and which parts of these plants are used. Recording the indigenous knowledge of medicinal plants is an urgent task. Traditional knowledge is usually passed verbally from generation to generation, and valuable information about medicinal plants is easily lost if not preserved in written form. The main objective of the present study was therefore to survey and to document the scattered indigenous knowledge of medicinal plants of the Miandam valley as basis for future phytochemical and pharmacological studies. Moreover, and for the first time in any region of Pakistan, the medicinal plants of the study area are classified according to biological and distributional properties as well as ecological preference. It is essential to know where and in which habitats ethno-medicinal plants occur; as such knowledge is a prerequisite to identify vulnerable plant species susceptible to collecting or habitat change. 


\section{Study area}

The valley of Miandam, Swat, is a well-known summer resort in northern Pakistan. Located about 50 $\mathrm{km}$ northeast of Saidu Sharif, the valley lies between $35^{\circ} 1^{\prime}-5^{\prime} \mathrm{N}, 72^{\circ} 30^{\prime}-37^{\prime} \mathrm{E}$ in the mountain range of Hindu Raj (Porter, 1970). The study area ranges between 1400 to $3500 \mathrm{~m}$ a.s.l. It is a narrow valley with a number of gorges, bounded on the north, east and south by high mountains. Its western boundary is the river Swat. Gujars (Indian Aryans) and Yousafzai (Pakhtoon) are the two main tribes residing in the area. Their main source of income is agriculture (nearly 41\%) (Rashid, 1999) and most of the population of the study area is directly or indirectly engaged in it. Miandam is a mountainous region and the cultivated land is insufficient for subsistence. Additional sources of income are daily wages and salaries (20\%), foreign and domestic remittances (17\%), forest products including medicinal plants (12\%) and other professions (10\%). Findings from (Rabbi et al. 2010) reveal that $59 \%$ of the households in north-western Pakistan derive their income from the forests.

Due to its considerable variation in altitude, temperature, topography, soil type and moisture, the vegetation of Miandam Valley can be classified into a series of altitudinal belts, namely dominated by Olea ferruginea and Quercus oblongata (submontane), Pinus wallichiana, Abies pindrow, Picea smithiana and Quercus semecarpifolia (montane), and alpine-subalpine flora, respectively (Adnan et al. 2006).See also the vegetation maps of the northern Pakistan regions of Chitral and Hunza (Nüsser and Dickoré, 2002; Eberhardt et al. 2007).

\section{Methods}

Regular field surveys were carried out in the Miandam valley from September 2010 through July 2011 in order to document the habitats and indigenous uses of ethno-medicinal plants of the valley. The surveys were carried out at different seasons so as to obtain identifiable plants and multiple information and also to cross-check the information provided by the local informants during earlier visits. We interviewed a small group of chiefly elder people of both Gujars and Yousufzai tribes who were highly esteemed in their societies due to their sound knowledge of medicinal plants. Structured questionnaires, formal and informal interviews and participatory observations were used to inquire about vernacular names, used plant parts and the process of remedy preparation. We did not encounter controversial issues among the informants but commonly received complementary information. Moreover, for each plant species growth forms (tree, shrub, woody climber, perennial herb, annual or biennial herb), plant status (indigenous, established alien, cultivated), abundance in the area (common, scattered, rare) and habitat preferences (arable fields, ruderal sites, wetland, woodland, mountain grassland) were recorded. Voucher specimens were identified using relevant standard literature (Nasir and Ali, 1970; Nasir and Ali, 1982; Nasir et al. 1972; Ali and Qaiser, 1993) and submitted to the Herbarium PUP at the Department of Botany, University of Peshawar. Plant nomenclature was 
updated using the World Checklist of Selected Plant Families (http://apps.kew.org/wcsp/home.do) and The Plant List (www.theplantlist.org/).Family assignation in this paper follows the Flora of Pakistan (Ali and Qaiser, 1993).

\section{Results and discussion}

\section{Plant diversity, use and applications}

A total of 106 ethno-medicinal plant species belonging to 96 genera and 54 plant families were recorded. The plants have been used to treat a wide range of diseases from simple headache to complex disorders of kidney and liver. The results are presented in Table 1with family names in alphabetical order, taxon name, local name, parts used, medicinal use, growth form, plant status, frequency and habitat preference. Perennial herbs were the most common growth form (Figure 2) among medicinal plants (43\%), followed by annuals and biennials (23\%), shrubs (16\%) and trees $(15 \%)$ As far as documented the use of herbs for remedy preparation in the study area is in consistence with other studies (Ali and Qaiser, 2009; Abbasi et al. 2009; Adnan and Hölscher, 2010; Ali et al. 2011; Awan et al. 2011; Badshah and Hussain, 2011; Hazrat et al. 2010; Iqbal and Sher, 2011; Jabeen et al. 2009; Jan et al. 2011; Khan et al. 2011a; Mahmood et al. 2011; Razaq et al. 2010; Pieroni et al. 2008; Teklehaymanot and Giday, 2007; Yineger et al. 2008).

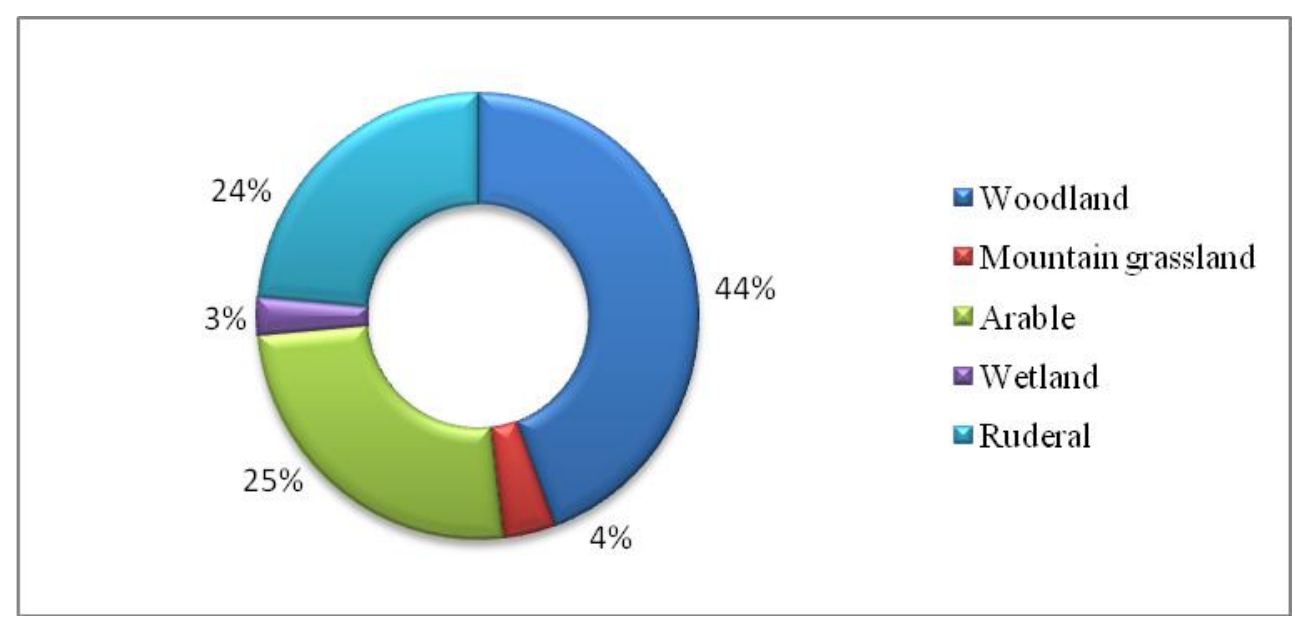

Figure 1. Habitat types of medicinal plants.

Ninety-nine of the species (93\%) are used for human ailments, three species (3\%) for livestock cure and four (4\%) to treat both human and livestock ailments. No less than 44 plant species were used to treat gastro-intestinal disorders such as dyspepsia, dysentery and stomach-ache followed by the treatment of dermatological diseases with more than 25 herbal remedies. Ten species were used against skeleto-muscular complaints like rheumatism, backache and muscular pain. Sixteen species were used to cure respiratory problems such as cough and asthma, fourteen for urinary complaints, twelve for cardio-vascular complaints and circulatory diseases, twelve to treat fever and headache, 


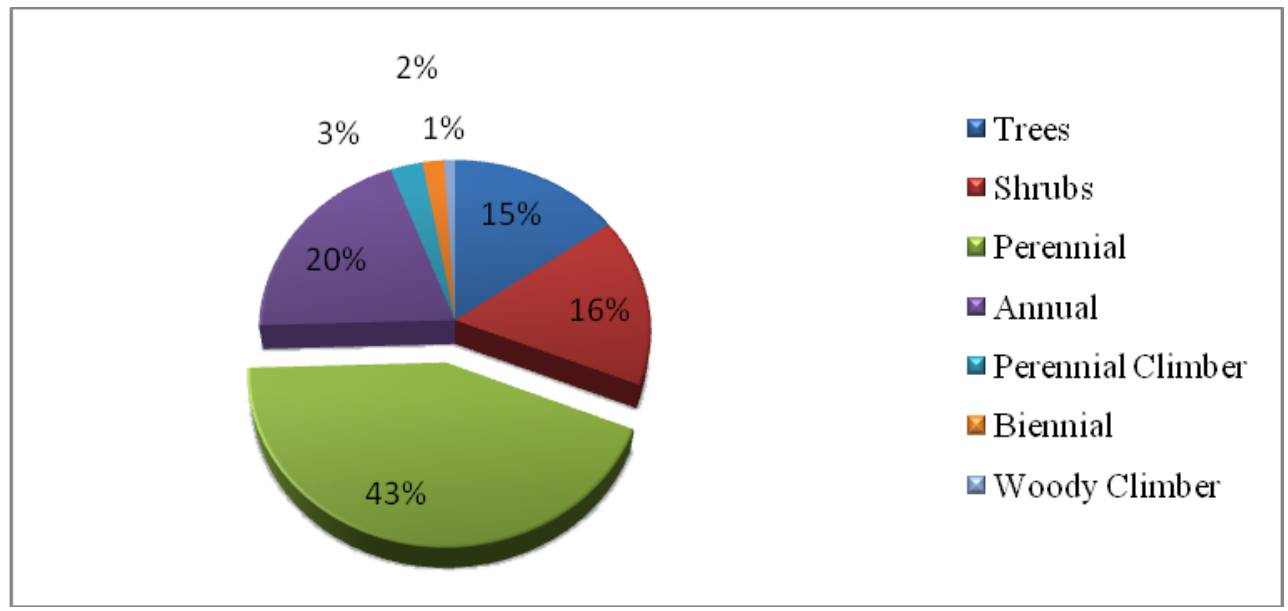

Figure 2. Growth forms of medicinal plants.

eleven for genital and sexual diseases, six for dental problems, six for ear, nose, throat (ENT) and eyes diseases, two for nerve disorders, one species (Spiraea sp.) was used to ease childbirth, and eighteen species for other purposes (wounds, cuts, narcotic, tonic, anticancer and tumor) (Table 2). The leaves of Skimmia laureola are used for spiritual purposes.

A single plant species may be used to cure several human ailments (Table 2). Some of the remedies

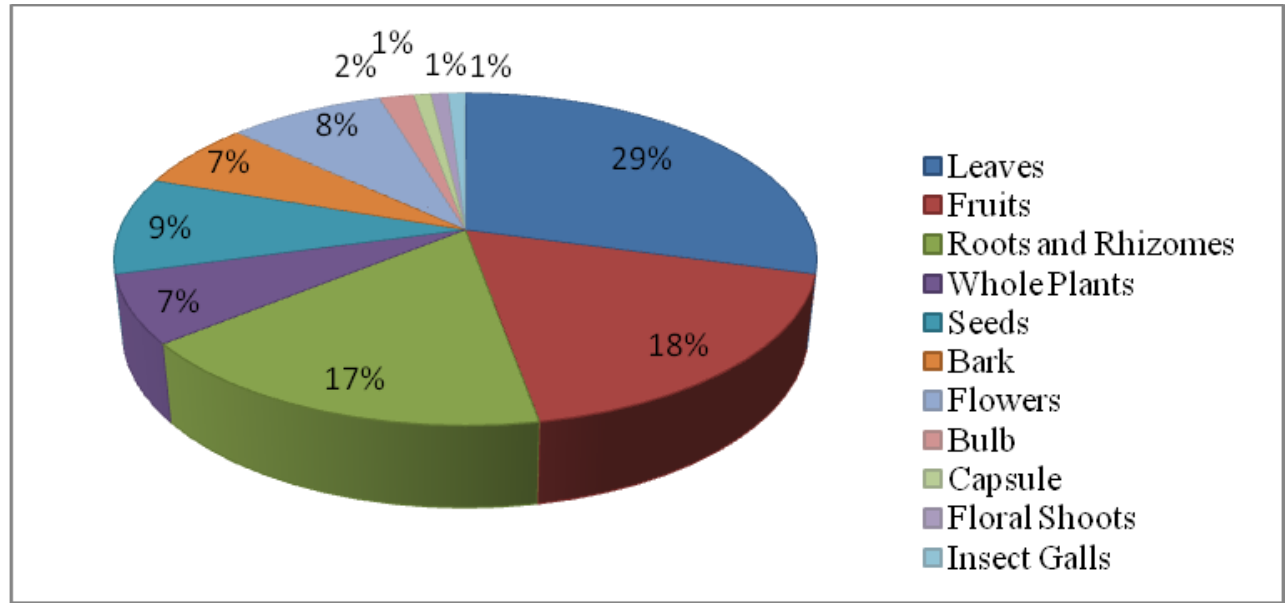

Figure 3. Use of different plant parts in the preparation of remedies in the research area.

were prepared by combining different plants such as the powdered rhizome of Dioscorea deltoidea mixed with powdered root of Berberis lycium for the treatment of jaundice and ulcers. Similarly, root decoction of Geranium wallichianum with pods of Pistacia chinensis was used for curing urinary complaints, cough and fever. According to traditional healers, complex medicines of two or more plant species are more potent than those prepared with single species. This has been attributed to interactive effects of the plants (Okello and Ssegawa, 2007). The most common medicinal recipe preparation was in powder form followed by decoction, infusion, juices, poultice and paste. The traditional healers and local herbalists of the region usually utilize every part of the plant. However, the use of a particular plant part depends on the plant habit and user's needs. The most frequently used plant parts (Figure 3) in the preparation of herbal remedies were leaves (29\%), followed by fruit (18\%), roots and rhizomes 
(17\%), and whole plants (7\%). Seeds (9\%), flowers (8\%), bark (7\%), bulbs (2\%), capsules, floral shoots and insect galls (1\% each) have also been used. The use of specific plant parts suggests that these parts have strongest medicinal properties but it needs biochemical analysis and pharmaceutical screening to cross-check the local information. Our findings of the frequent use of green leaves in the preparation of remedies corroborate the results of (Kala, 2005; Muthu et al. 2006; Murad et al. 2011; Adnan et al. 2012; Bhat et al. 2013).

Different liquids such as water, juices, sugar, tea, honey, mustard oil, desi ghee (butter) and milk are mixed with plants or plant parts during the preparation of the remedies. The prepared remedies are mostly administered orally (77\%), less frequently dermally (10\%) or both orally and dermally (12\%). Only $1 \%$ is administered through ears or eyes.

\section{Habitats and conservation of ethno-medicinal plants}

Eighty out of 106 medicinal plants are indigenous to the area while the others are cultivated (20) or established alien plants (6). The latter groups are of no conservation concern as they are common (20) or scattered (7) in the study area. Also among the indigenous medicinal plants the majority of species is common (61\%) or scattered (33\%) in the area, thus neither of immediate conservation concern. Only five medicinal plant species (6\%) are rare in the study area: Aconitum violaceum, Colchicum luteum, Elaeagnus umbellata, Jasminum humile and Sambucus wightiana. Sambucus and Elaeagnus are woodland shrubs of which leaves and fruits or leaves and flowers, respectively, are collected for medicinal purposes. Since this kind of harvesting is non-destructive, the rarity of the shrub species is apparently not caused by overcollection. In contrast, populations of Aconitum violaceum, Colchicum luteum and Jasminum humile may be harmed since rhizomes, corms or whole plants are collected, respectively. In these cases, plant populations should be monitored to avoid overcollection.

The synanthropic flora (i.e., occurring in arable fields or ruderal sites) contains a high proportion of the ethno-medicinal plants. Slightly under 50\% (51) out of the 106 ethno-medicinal plant species occur in man-made habitats (in arable fields 27 species, most of which being cultivated; another 24 in ruderal sites). Since they can be expected to grow abundantly in or near settlements, or are even cultivated and harvested, they may be collected without much effort, and in suitable quantities. Slightly more than 50\% (55) of the ethno-medicinal plant species encountered in the study area occur in semi-natural habitats (though extensively grazed or otherwise used). Most species of the latter group (47) occurred in different kinds of woodland (Figure 1), while only few occur in wetlands (4) and mountain grasslands (4). Mountain grassland medicinal plants known in the Miandam valley comprise Colchicum luteum, Corydalis stewartii, Nepeta cataria and Thymus linearis. Since Himalayan mountain floras are rich (Adnan et al. 2012; Bhat et al. 2013; Khan et al. 2013b) and the local almost certainly contains more species of pharmaceutical value, we assume that the habitat is too 
remote and too difficult to access to be of much interest as a "medicinal plant hunting area" for the people in the Miandam valley.

Woodlands are the main source for non-synanthropic indigenous medicinal plants. They comprise 21 woody plants (apart from the climber Hedera nepalensis, seven trees and thirteen shrubs), two shortlived and 24 perennial herbs. Almost half of the perennial herbs are dug to collect the stem base (Primula denticulata) or chiefly the rhizomes (Aconitum violaceum, Arisaema jacquemontii, Bergenia stracheyi, Delphinium denudatum, Dioscorea deltoidea, Paeonia emodi, Podophyllum hexandrum, Polygonatum multiflorum, Polygonatum verticillatum). Except the latter two, these species are rangerestricted taxa of Himalayan or narrower distribution. Due to their biochemical components they are largely unpalatable for livestock, hence fairly resistant under the widespread practice of wood-pasture, but may be vulnerable to overcollecting for medicinal purposes, although so far only Aconitum violaceum is considered rare in the study area. A currently more serious threat to the ethno-medicinal plant wealth of the woodlands as well as to the social and economic basis of the rural population in northern Pakistan is excessive timber exploitation leading to deforestation and habitat destruction.

\section{Conclusion}

The Miandam valley in northern Pakistan is very rich in commercially and pharmaceutically important ethno-medicinal plant species. The locals, in particular traditional healers, have centuries-old knowledge regarding the uses of the plants, and the locals use these species in a traditional way for curing a wide spectrum of diseases. Few species were found to be vulnerable probably due to overcollection. Especially perennial woodland herbs with rhizomes are of conservation concern. The local inhabitants depend on plants for the treatment of diseases but not all are familiar with the proper collection, parts to be used, preservation and storage. In contrast, local traditional healers are familiar with proper collection and use of medicinal plants, and they should be involved in efforts of conservation and sustainable use of ethno-medicinal plant resources. In view of the outstanding importance of woodlands and forests in northern Pakistan the currently widespread and uncontrolled deforestation is a serious threat both to ecological and social sustainability as well as to the long-term economic basis of the local population (Rabbi et al. 2010).It is also a threat to the ethno-medicinal plant wealth. For purposes of plant conservation and to increase the locals' income we suggest to cultivate vulnerable woodland medicinal plants of commercial value in newly designed and locally administered self-government agroforestry systems. Due to the specific habitat demands of many woodland plant species better results may be obtained through well managed agroforestry systems than in ex-situ sites (Sher et al. 2010). 
Table 1. Medicinal plants of the Miandam area with their medicinal properties, and biological, ecological and chorological characteristics.

\begin{tabular}{|c|c|c|c|c|c|c|c|c|}
\hline Plant family & Taxon name & Local name & Parts used & Medicinal uses, remedies & $\begin{array}{l}\text { Growth } \\
\text { form }\end{array}$ & $\begin{array}{l}\text { Plant } \\
\text { status }\end{array}$ & Frequency & Habitat \\
\hline Amaranthaceae & Amaranthus viridis & Chalvaray & Leaves & $\begin{array}{l}\text { Leaf extract is emollient, also used for } \\
\text { curing cough and asthma. }\end{array}$ & Annual & Indigenous & Common & Ruderal \\
\hline Anacardiaceae & Pistacia chinensis & Shnai & $\begin{array}{l}\text { Insect galls, } \\
\text { leaves and } \\
\text { bark }\end{array}$ & $\begin{array}{l}\text { Powdered insect galls, bark and leaves } \\
\text { are topical antiseptic, also for curing } \\
\text { jaundice and liver diseases. }\end{array}$ & Tree & $\begin{array}{l}\text { Established } \\
\text { alien }\end{array}$ & Scattered & Woodland \\
\hline Apiaceae & Bupleurum longicaule & Gillo & Whole plant & $\begin{array}{l}\text { Powdered plant is mixed with milk and } \\
\text { used as laxative }\end{array}$ & Perennial & Indigenous & Common & Woodland \\
\hline Apiaceae & Coriandrum sativum & Dhanyal & Whole plant & Stimulant and carminative & Annual & Cultivated & Common & Arable \\
\hline Apiaceae & Foeniculum vulgare & $\begin{array}{l}\text { Kaga } \\
\text { vanalay }\end{array}$ & Fruit & $\begin{array}{l}\text { Powdered fruit is mixed with sugar, } \\
\text { taken with a cup of milk for curing } \\
\text { urinary problems (dysuria); dry fruits are } \\
\text { carminative and laxative }\end{array}$ & Annual & Cultivated & Common & Arable \\
\hline Apiaceae & Pimpinella diversifolia & Watani kaga & Fruit & Powdered fruits are carminative & Perennial & Indigenous & Scattered & Woodland \\
\hline Apiaceae & Heracleum candicans & Kadu panra & Root & $\begin{array}{l}\text { Decoction of root against colic and } \\
\text { asthma }\end{array}$ & Perennial & Indigenous & Scattered & Wetland \\
\hline Araceae & Arisaema jacquemontii & Marjarai & Rhizome & $\begin{array}{l}\text { Rhizome bolus is given orally to } \\
\text { livestock for respiratory problems }\end{array}$ & Perennial & Indigenous & Scattered & Woodland \\
\hline Araliaceae & Hedera nepalensis & Prewata & Leaves & $\begin{array}{l}\text { Juice from leaves for curing diabetes, } \\
\text { also considered as blood purifier }\end{array}$ & $\begin{array}{l}\text { Woody } \\
\text { climber }\end{array}$ & Indigenous & Common & Woodland \\
\hline Asclepiadaceae & Periploca aphylla & Barara & Stem, fruits & $\begin{array}{l}\text { Milky juice of stem and fruit applied to } \\
\text { swellings; stem latex as antimycotic for } \\
\text { curing dermatitis in livestock }\end{array}$ & Shrub & Indigenous & Common & Ruderal \\
\hline Asteraceae & Artemisia scoparia & Jaukay & $\begin{array}{l}\text { Shoot and } \\
\text { seeds }\end{array}$ & $\begin{array}{l}\text { Respiratory stimulant, anthelmintic, } \\
\text { purgative and against earache }\end{array}$ & Biennial & Indigenous & Common & Woodland \\
\hline Asteraceae & Cichorium intybus & Han & Root & $\begin{array}{l}\text { Decoction of fresh root for treatment of } \\
\text { fever }\end{array}$ & Perennial & Indigenous & Common & Ruderal \\
\hline Asteraceae & Echinops echinatus & $\begin{array}{l}\text { Ghwand } \\
\text { Saray } \\
\text { Ghanowala }\end{array}$ & Root & $\begin{array}{l}\text { Powdered root applied to wounds of } \\
\text { cattle for killing maggots; also to kill lice }\end{array}$ & Perennial & Indigenous & Scattered & Wetland \\
\hline Asteraceae & Launaea procumbens & Shauda pai & Leaves & $\begin{array}{l}\text { Mixture of powdered leaves with sugar } \\
\text { to enhance lactation in livestock }\end{array}$ & Perennial & Indigenous & Common & Ruderal \\
\hline Asteraceae & Sonchus asper & Shauda pai & Shoot & $\begin{array}{l}\text { Shoots fed to livestock for enhancing } \\
\text { lactation }\end{array}$ & Annual & Indigenous & Common & Ruderal \\
\hline Asteraceae & Taraxacum sp. & Ziar gulai & Leaves and & Grinded leaves are tonic, root decoction & Perennial & Indigenous & Common & Ruderal \\
\hline
\end{tabular}




\begin{tabular}{|c|c|c|c|c|c|c|c|c|}
\hline Plant family & Taxon name & Local name & Parts used & Medicinal uses, remedies & $\begin{array}{l}\text { Growth } \\
\text { form }\end{array}$ & $\begin{array}{l}\text { Plant } \\
\text { status }\end{array}$ & Frequency & Habitat \\
\hline Asteraceae & Xanthium strumarium & Ghishkay & $\begin{array}{l}\text { roots } \\
\text { Leaves }\end{array}$ & $\begin{array}{l}\text { against kidney and liver disorders } \\
\text { Leaf decoction recommended in malarial } \\
\text { fever }\end{array}$ & Annual & Indigenous & Common & Ruderal \\
\hline Berberidaceae & Berberis lycium & Kwaray & Root bark & $\begin{array}{l}\text { Dried root bark given orally as body } \\
\text { tonic }\end{array}$ & Shrub & Indigenous & Scattered & Woodland \\
\hline Berberidaceae & $\begin{array}{l}\text { Podophyllum } \\
\text { hexandrum }\end{array}$ & Kakora & Rhizome & $\begin{array}{l}\text { Powdered rhizome used to cure liver } \\
\text { diseases }\end{array}$ & Perennial & Indigenous & Scattered & Woodland \\
\hline Boraginaceae & $\begin{array}{l}\text { Cynoglossum } \\
\text { lanceolatum }\end{array}$ & Gat gul & Whole plant & $\begin{array}{l}\text { Powdered plant taken with a decoction } \\
\text { of Coriandrum sativum fruits as laxative }\end{array}$ & Perennial & Indigenous & Common & Woodland \\
\hline Boraginaceae & Onosma hispida & $\begin{array}{l}\text { Khwaga } \\
\text { abai }\end{array}$ & Root & $\begin{array}{l}\text { Used to color mustard oil which is } \\
\text { applied for smoothing hair }\end{array}$ & Perennial & Indigenous & Common & Ruderal \\
\hline Brassicaceae & Brassica campestris & Sharshum & Seeds & $\begin{array}{l}\text { Oil, extracted from seeds, is used as } \\
\text { ointment, for massage of body and hair }\end{array}$ & Annual & Cultivated & Common & Arable \\
\hline Brassicaceae & $\begin{array}{l}\text { Brassica campestris } \\
\text { var. rapa }\end{array}$ & Tepar & Leaves, roots & Against stomachache and ulcer problems & Annual & Cultivated & Common & Arable \\
\hline Brassicaceae & $\begin{array}{l}\text { Capsella bursa- } \\
\text { pastoris }\end{array}$ & Bambesa & $\begin{array}{l}\text { Leaves and } \\
\text { seeds }\end{array}$ & $\begin{array}{l}\text { Paste of fresh leaves with milk for curing } \\
\text { diarrhea; seeds are stimulant and diuretic }\end{array}$ & Annual & Indigenous & Common & Ruderal \\
\hline Brassicaceae & Nasturtium officinale & Talmera & Young shoot & $\begin{array}{l}\text { Young shoot against constipation and } \\
\text { stomachache }\end{array}$ & Perennial & Indigenous & Common & Wetland \\
\hline Buxaceae & Sarcococca saligna & Ladanr & Leaves & $\begin{array}{l}\text { Heated in mustard oil and applied to } \\
\text { muscular pain; infusion of leaves orally } \\
\text { for rheumatism }\end{array}$ & Perennial & Indigenous & Common & Woodland \\
\hline Cannabaceae & Cannabis sativa & Bang & Leaves & $\begin{array}{l}\text { Leaves in bandage for wound healing; } \\
\text { powdered leaves as anodyne, sedative, } \\
\text { tonic and narcotic; juice added with milk } \\
\text { and nuts as a cold drink ("Tandai") } \\
\text { generating a pleasant excitement; } \\
\text { "Charas" is also prepared from it }\end{array}$ & Annual & Indigenous & Common & Arable \\
\hline Caprifoliaceae & Sambucus wightiana & Benakai & $\begin{array}{l}\text { Leaves, } \\
\text { fruits and } \\
\text { flowers }\end{array}$ & $\begin{array}{l}\text { Poultice from leaves and flowers to treat } \\
\text { burns and rheumatism; berries are } \\
\text { purgative and used in dropsy }\end{array}$ & Shrub & Indigenous & Rare & Woodland \\
\hline Caprifoliaceae & $\begin{array}{l}\text { Viburnum } \\
\text { grandiflorum }\end{array}$ & Ghuz meva & fruit & $\begin{array}{l}\text { Fresh fruit is eaten to cure stomach } \\
\text { problems }\end{array}$ & Shrub & Indigenous & Common & Woodland \\
\hline Caryophyllaceae & Arenaria griffithii & Kinar & Shoots & $\begin{array}{l}\text { Dried shoot powder with honey after } \\
\text { meal as antispasmodic }\end{array}$ & Perennial & Indigenous & Common & Woodland \\
\hline Caryophyllaceae & Silene vulgaris & Matorangay & Shoot & $\begin{array}{l}\text { Shoot against stomachache and as } \\
\text { emollient }\end{array}$ & Perennial & Indigenous & Common & Woodland \\
\hline
\end{tabular}




\begin{tabular}{|c|c|c|c|c|c|c|c|c|}
\hline Plant family & Taxon name & Local name & Parts used & Medicinal uses, remedies & $\begin{array}{l}\text { Growth } \\
\text { form }\end{array}$ & $\begin{array}{l}\text { Plant } \\
\text { status }\end{array}$ & Frequency & Habitat \\
\hline Caryophyllaceae & Stellaria media & Oulalai & Whole plant & Decoction is considered as purgative & Annual & Indigenous & Common & Arable \\
\hline Chenopodiaceae & Chenopodium album & Sarmay & Whole plant & $\begin{array}{l}\text { Dried powdered plant considered as } \\
\text { carminative and diuretic agent }\end{array}$ & Annual & Indigenous & Common & Ruderal \\
\hline Clusiaceae & Hypericum perforatum & Shin chai & Shoot & $\begin{array}{l}\text { Used as diuretic and its tea is stimulant } \\
\text { and analgesic }\end{array}$ & Perennial & Indigenous & Scattered & Woodland \\
\hline Convolvulaceae & Convolvulus arvensis & Prewatai & Whole plant & Purgative, also applied in skin disorders & $\begin{array}{l}\text { Perennial, } \\
\text { climber }\end{array}$ & Indigenous & Common & Arable \\
\hline Cuscutaceae & Cuscuta reflexa & Zelai & Whole plant & $\begin{array}{l}\text { Decoction for urine control, diabetes and } \\
\text { blood purification; plant extract used as } \\
\text { anti-lice }\end{array}$ & $\begin{array}{l}\text { Perennial, } \\
\text { climber }\end{array}$ & $\begin{array}{l}\text { Established } \\
\text { alien }\end{array}$ & Scattered & Arable \\
\hline Dioscoreaceae & Dioscorea deltoidea & Kanis zelai & Rhizome & $\begin{array}{l}\text { Powdered rhizome mixed with powdered } \\
\text { root of Berberis lycium, the mixture is } \\
\text { used for treatment of jaundice and ulcers }\end{array}$ & $\begin{array}{l}\text { Perennial, } \\
\text { climber }\end{array}$ & Indigenous & Scattered & Woodland \\
\hline Ebenaceae & Diospyros kaki & Sur amlok & Ripe fruits & Laxative & Tree & Cultivated & Common & Arable \\
\hline Ebenaceae & Diospyros lotus & Tour amlok & $\begin{array}{l}\text { Dried ripe } \\
\text { fruits }\end{array}$ & $\begin{array}{l}\text { Carminative, purgative and causing } \\
\text { flatulence; boiled in milk and taken } \\
\text { against constipation and dysentery }\end{array}$ & Tree & Cultivated & Common & Arable \\
\hline Elaeagnaceae & Elaeagnus umbellata & $\begin{array}{l}\text { Ghanum } \\
\text { ranga }\end{array}$ & $\begin{array}{l}\text { Flowers, } \\
\text { leaves }\end{array}$ & $\begin{array}{l}\text { Decoction of flowers used twice a day to } \\
\text { cure heart diseases; decoction of leaves } \\
\text { against cough; mature raw seeds eaten as } \\
\text { vitamin C source }\end{array}$ & Shrub & Indigenous & Rare & Woodland \\
\hline Euphorbiaceae & Euphorbia wallichii & Shangla & Whole plant & $\begin{array}{l}\text { Dried leaves and seeds given to children } \\
\text { in bowel complains; plant juice against } \\
\text { ringworm }\end{array}$ & Perennial & Indigenous & Common & Woodland \\
\hline Euphorbiaceae & Ricinus communis & Harhanda & Seeds & $\begin{array}{l}\text { Seed oil demulcent and to evacuate } \\
\text { bowels in children }\end{array}$ & Shrub & $\begin{array}{l}\text { Established } \\
\text { alien }\end{array}$ & Scattered & Ruderal \\
\hline Fabaceae & Indigofera heterantha & Ghwarija & $\begin{array}{l}\text { Root and } \\
\text { leaves }\end{array}$ & $\begin{array}{l}\text { Dried powdered root taken with glass of } \\
\text { water against scabies; leaves against } \\
\text { stomach problems }\end{array}$ & Shrub & Indigenous & Common & Woodland \\
\hline Fabaceae & Lathyrus aphaca & Korkamanai & Seed & $\begin{array}{l}\text { Decoction of the seed } 3 \text { times a day for } \\
\text { wound healing }\end{array}$ & Annual & Indigenous & Scattered & Arable \\
\hline Fabaceae & Lotus corniculatus & Fateh khana & Whole plant & $\begin{array}{l}\text { Decoction of dried powdered plant with } \\
\text { ghee or boiled water against sexual } \\
\text { debility and backache }\end{array}$ & Perennial & Indigenous & Scattered & Woodland \\
\hline Fagaceae & Quercus oblongata & Banj & Fruit & Powdered fruits in urinary infection & Tree & Indigenous & Common & Woodland \\
\hline Fagaceae & Quercus floribunda & Tour banj & Fruit & $\begin{array}{l}\text { Powdered fruits for treating gonorrhea } \\
\text { and urinary disease }\end{array}$ & Tree & Indigenous & Common & Woodland \\
\hline
\end{tabular}




\begin{tabular}{|c|c|c|c|c|c|c|c|c|}
\hline Plant family & Taxon name & Local name & Parts used & Medicinal uses, remedies & $\begin{array}{l}\text { Growth } \\
\text { form }\end{array}$ & $\begin{array}{l}\text { Plant } \\
\text { status }\end{array}$ & Frequency & Habitat \\
\hline Fumariaceae & Corydalis stewartii & Mamera & Floral shoot & $\begin{array}{l}\text { Decoction of floral shoot to cure eye } \\
\text { diseases }\end{array}$ & Biennial & Indigenous & Scattered & $\begin{array}{l}\text { Mountain } \\
\text { grassland }\end{array}$ \\
\hline Geraniaceae & $\begin{array}{l}\text { Geranium } \\
\text { wallichianum }\end{array}$ & Srazela & Root & $\begin{array}{l}\text { Root decoction with pods of Pistacia } \\
\text { chinensis to treat cough and fever and } \\
\text { urinary complaints }\end{array}$ & Perennial & Indigenous & Common & woodland \\
\hline Hippocastanaceae & Aesculus indica & Jawaz & $\begin{array}{l}\text { Seeds and } \\
\text { bark }\end{array}$ & $\begin{array}{l}\text { Fruits are anthelmintic and given to } \\
\text { horses in colic; plant oil externally used } \\
\text { against rheumatism; nuts against colic } \\
\text { and to cure chest diseases in horses, } \\
\text { donkeys and mules }\end{array}$ & Tree & Indigenous & Scattered & Woodland \\
\hline Juglandaceae & Juglans regia & Ghwaz & $\begin{array}{l}\text { Fruit, bark, } \\
\text { leaves }\end{array}$ & $\begin{array}{l}\text { Dried fruit mixed with coconut and } \\
\text { honey used as tonic; bark (locally called } \\
\text { Dandasa) for cleaning and sparkling of } \\
\text { teeth; decoction of leaves against eczema } \\
\text { and intestinal worms }\end{array}$ & Tree & Cultivated & Common & Arable \\
\hline Lamiaceae & Ajuga bracteosa & Booti & Whole plant & $\begin{array}{l}\text { Locally, decoction of the plant or its } \\
\text { powder swallowed with water before } \\
\text { breakfast for the treatment of throat sore, } \\
\text { internal colic, purifying blood and } \\
\text { epilepsy; decoction for curing jaundice } \\
\text { and hypertension }\end{array}$ & Perennial & Indigenous & Common & Ruderal \\
\hline Lamiaceae & Mentha spicata & Podina & $\begin{array}{l}\text { Leaves and } \\
\text { stem }\end{array}$ & Carminative & Perennial & Cultivated & Common & Arable \\
\hline Lamiaceae & Mentha royleana & Valenay & whole plant & $\begin{array}{l}\text { Decoction of leaves for treatment of } \\
\text { diarrhea in children; powdered plant } \\
\text { mixed with sugar for prevention of } \\
\text { vomiting and dyspepsia }\end{array}$ & Perennial & Indigenous & Common & Ruderal \\
\hline Lamiaceae & Nepeta cataria & Pisho botai & $\begin{array}{l}\text { Flowers and } \\
\text { leaves }\end{array}$ & $\begin{array}{l}\text { Dried leaves and flowering tops } \\
\text { carminative }\end{array}$ & Perennial & Indigenous & Scattered & $\begin{array}{l}\text { Mountain } \\
\text { grassland }\end{array}$ \\
\hline Lamiaceae & Otostegia limbata & Spin azghai & Whole plant & $\begin{array}{l}\text { Juice of leaves applied to gums for } \\
\text { treatment of gum problem in children; } \\
\text { dried powder of plant is used in jaundice }\end{array}$ & Perennial & Indigenous & Common & Woodland \\
\hline Lamiaceae & Isodon rugosus & Spearkai & Leaves & $\begin{array}{l}\text { Dried leaves put in mouth as remedy for } \\
\text { toothache }\end{array}$ & Shrub & Indigenous & Common & Woodland \\
\hline Lamiaceae & Origanum vulgare & Shamakay & Whole plant & $\begin{array}{l}\text { Diuretic and against toothache and } \\
\text { earache }\end{array}$ & Perennial & Indigenous & Common & Woodland \\
\hline Lamiaceae & Salvia lanata & Spera botai & Leaves & Paste of leaves applied to toes laceration & Perennial & Indigenous & Scattered & Woodland \\
\hline
\end{tabular}




\begin{tabular}{|c|c|c|c|c|c|c|c|c|}
\hline Plant family & Taxon name & Local name & Parts used & Medicinal uses, remedies & $\begin{array}{l}\text { Growth } \\
\text { form }\end{array}$ & $\begin{array}{l}\text { Plant } \\
\text { status }\end{array}$ & Frequency & Habitat \\
\hline Lamiaceae & Salvia moorcroftiana & Kherghwag & Leaves & $\begin{array}{l}\text { in hot and moist season } \\
\text { Brassica campestris oil applied to fresh } \\
\text { leaves tied round for healing of wounds }\end{array}$ & Perennial & Indigenous & Common & Ruderal \\
\hline Lamiaceae & Thymus linearis & Chi botai & Shoots & $\begin{array}{l}\text { Tea of shoots advised for treating pain } \\
\text { and fever }\end{array}$ & Perennial & Indigenous & Common & $\begin{array}{l}\text { Mountain } \\
\text { grassland }\end{array}$ \\
\hline Liliaceae & Allium sativum & Ouga & $\begin{array}{l}\text { Bulb and } \\
\text { leaves }\end{array}$ & $\begin{array}{l}\text { Boiled and the cooled extract } \\
\text { administered against diarrhea, dysentery } \\
\text { and for lowering blood pressure; bulbs } \\
\text { stimulant; leaves diuretic, aphrodisiac } \\
\text { and expectorant; antiseptic; juice applied } \\
\text { to soothe irritation caused by scorpion } \\
\text { and hornet stings }\end{array}$ & Perennial & Cultivated & Common & Arable \\
\hline Liliaceae & Allium сера & Piaz & $\begin{array}{l}\text { Bulb and } \\
\text { leaves }\end{array}$ & $\begin{array}{l}\text { Bulbs stimulant; leaves diuretic, } \\
\text { aphrodisiac and expectorant; also } \\
\text { antiseptic and juice applied to soothe } \\
\text { irritation caused by scorpion and hornet } \\
\text { sting; Mountaineers have it with them } \\
\text { while crossing high altitude passes as it } \\
\text { enhances the intake of oxygen }\end{array}$ & Perennial & Cultivated & Common & Arable \\
\hline Liliaceae & Colchicum luteum & $\begin{array}{l}\text { Qaimat } \\
\text { guallay }\end{array}$ & Whole plant & $\begin{array}{l}\text { Blood purifier, laxative and aphrodisiac; } \\
\text { fried corms are used for joints pain }\end{array}$ & Perennial & Indigenous & Rare & $\begin{array}{l}\text { Mountain } \\
\text { grassland }\end{array}$ \\
\hline Liliaceae & $\begin{array}{l}\text { Polygonatum } \\
\text { multiflorum }\end{array}$ & Noorealam & Rhizome & $\begin{array}{l}\text { Rhizome infusion against dysentery; } \\
\text { referred aphrodisiac }\end{array}$ & Perennial & Indigenous & Scattered & Woodland \\
\hline Liliaceae & $\begin{array}{l}\text { Polygonatum } \\
\text { verticillatum }\end{array}$ & Noorealam & Rhizome & Against rheumatism and as aphrodisiac & Perennial & Indigenous & Scattered & Woodland \\
\hline Malvaceae & $\begin{array}{l}\text { Abelmoschus } \\
\text { esculentus }\end{array}$ & Bhindi & Fruits & Emollient, demulcent and diuretic & Annual & Cultivated & Scattered & Arable \\
\hline Meliaceae & Melia azedarach & $\begin{array}{l}\text { Tora } \\
\text { bakyana, } \\
\text { shandai }\end{array}$ & $\begin{array}{l}\text { Fruits, } \\
\text { shoots, bark, } \\
\text { leaves }\end{array}$ & $\begin{array}{l}\text { Dried, crushed fruits against gastric } \\
\text { trouble, fever and cough; dry leaves } \\
\text { mixed with wheat flour used as } \\
\text { anthelmintic in livestock; decoction of } \\
\text { the bark considered anti-allergic; } \\
\text { extraction of leaves used by women } \\
\text { against head lice; leaves, young branches } \\
\text { or fermented fruits are given as } \\
\text { carminative to cattle, when belly is } \\
\text { swollen through gas accumulation due to }\end{array}$ & Tree & $\begin{array}{l}\text { Established } \\
\text { alien }\end{array}$ & Scattered & Woodland \\
\hline
\end{tabular}




\begin{tabular}{|c|c|c|c|c|c|c|c|c|}
\hline Plant family & Taxon name & Local name & Parts used & Medicinal uses, remedies & $\begin{array}{l}\text { Growth } \\
\text { form }\end{array}$ & $\begin{array}{l}\text { Plant } \\
\text { status }\end{array}$ & Frequency & Habitat \\
\hline Moraceae & Ficus palmata & Inzer & $\begin{array}{l}\text { Flowers and } \\
\text { fruits }\end{array}$ & $\begin{array}{l}\text { overeating } \\
\text { Fresh floral parts as demulcent; juice } \\
\text { extracted from fruit as expectorant }\end{array}$ & Tree & Cultivated & Common & Arable \\
\hline Moraceae & Morus alba & Toot & Fruit & Fruit to treat constipation and cough & Tree & Indigenous & Common & Arable \\
\hline Oleaceae & Jasminum humile & $\begin{array}{l}\text { Rambil } \\
\text { chambil }\end{array}$ & $\begin{array}{l}\text { Roots and } \\
\text { flowers }\end{array}$ & $\begin{array}{l}\text { Powdered roots as anthelmintic and } \\
\text { diuretic; juice extracted from flowers } \\
\text { against skin diseases, headache and } \\
\text { mouth rash }\end{array}$ & Shrub & Indigenous & Rare & Woodland \\
\hline Oleaceae & Olea europaea & Khona & Leaves & $\begin{array}{l}\text { Decoction of leaves as gargle considered } \\
\text { as remedy for toothache, mouth and gum } \\
\text { diseases }\end{array}$ & Tree & Cultivated & Scattered & Arable \\
\hline Oxalidaceae & Oxalis corniculata & Tarukey & Whole plant & Decoction of plant to enhance digestion & Annual & Indigenous & Common & Ruderal \\
\hline Paeoniaceae & Paeonia emodi & Mamekh & Rhizome & $\begin{array}{l}\text { Powdered rhizome with milk to cure } \\
\text { backache and general weakness }\end{array}$ & Perennial & Indigenous & Scattered & Woodland \\
\hline Papaveraceae & Papaver somniferum & Qashqash & $\begin{array}{l}\text { Capsule, } \\
\text { seeds }\end{array}$ & $\begin{array}{l}\text { Capsules and seeds as narcotic; dried } \\
\text { capsule to make tea for cough and fever }\end{array}$ & Annual & Indigenous & Scattered & Arable \\
\hline Plantaginaceae & Plantago lanceolata & Jabai & Leaves & $\begin{array}{l}\text { Leaves applied to treat bedsores, } \\
\text { inflamed surfaces and candidiasis }\end{array}$ & Perennial & Indigenous & Scattered & Ruderal \\
\hline Plantaginaceae & Plantago major & Ghwa jabai & Seeds, leaves & $\begin{array}{l}\text { Leaves applied to treat bedsores and } \\
\text { candidiasis }\end{array}$ & Perennial & Indigenous & Scattered & Ruderal \\
\hline Platanaceae & Platanus orientalis & Chinar & Bark & $\begin{array}{l}\text { Powdered bark taken orally to control } \\
\text { diarrhea }\end{array}$ & Tree & Indigenous & Scattered & Woodland \\
\hline Poaceae & Avena sativa & Jamdaray & Fruit & $\begin{array}{l}\text { Fried in ghee and milk, the paste is } \\
\text { considered as general body tonic and } \\
\text { aphrodisiac }\end{array}$ & Annual & Cultivated & Common & Arable \\
\hline Poaceae & Cynodon dactylon & Kabal & Whole plant & $\begin{array}{l}\text { Decoction as blood purifier and to } \\
\text { control nose bleed; chewed and placed } \\
\text { on wound to stop bleeding and as topical } \\
\text { anti-septic }\end{array}$ & Perennial & Indigenous & Common & Ruderal \\
\hline Polygonaceae & Rumex dentatus & Shalkhay & $\begin{array}{l}\text { Rhizome, } \\
\text { leaves }\end{array}$ & $\begin{array}{l}\text { Rhizome and leaves as poultice for } \\
\text { wound healing }\end{array}$ & Annual & Indigenous & Common & Ruderal \\
\hline Portulacaceae & Portulaca oleracea s.l. & Warkharae & Shoot & $\begin{array}{l}\text { Shoot decoction against liver and kidney } \\
\text { diseases }\end{array}$ & Annual & Cultivated & Common & Arable \\
\hline Primulaceae & Primula denticulata & Mamera & Stem base & Infusion of young stem base ophthalmic & Perennial & Indigenous & Common & Woodland \\
\hline Punicaceae & Punica granatum & $\begin{array}{l}\text { Nangoray, } \\
\text { Anar }\end{array}$ & Fruit & $\begin{array}{l}\text { Dried fruit in bolus form for removal of } \\
\text { intestinal helminths }\end{array}$ & Shrub & Cultivated & Scattered & Arable \\
\hline Ranunculaceae & Aconitum violaceum & Zaharmora, & Rhizome & Rhizomes, wrapped in sheep or goat & Perennial & Indigenous & Rare & Woodland \\
\hline
\end{tabular}




\begin{tabular}{|c|c|c|c|c|c|c|c|c|}
\hline Plant family & Taxon name & Local name & Parts used & Medicinal uses, remedies & $\begin{array}{l}\text { Growth } \\
\text { form }\end{array}$ & $\begin{array}{l}\text { Plant } \\
\text { status }\end{array}$ & Frequency & Habitat \\
\hline & & $\begin{array}{l}\text { Da Ghra } \\
\text { Zahar }\end{array}$ & & $\begin{array}{l}\text { intestine and thoroughly boiled in milk; } \\
\text { milk discarded and rhizomes crushed } \\
\text { into powder, taken against rheumatism } \\
\text { and arthritis; administering as such may } \\
\text { cause death or mental problems if } \\
\text { overdozed }\end{array}$ & & & & \\
\hline Ranunculaceae & Caltha alba & Makan path & Leaves & Leaves laxative in nature & Perennial & Indigenous & Scattered & Wetland \\
\hline Ranunculaceae & $\begin{array}{l}\text { Delphinium } \\
\text { denudatum }\end{array}$ & Jadwar & Rhizome & $\begin{array}{l}\text { Rhizome powder with water to cure } \\
\text { cough and fever }\end{array}$ & Perennial & Indigenous & Scattered & Woodland \\
\hline Rosaceae & Fragaria bucharica & $\begin{array}{l}\text { Da zmaki } \\
\text { toot }\end{array}$ & Root, fruit & $\begin{array}{l}\text { Powdered root useful in disease of } \\
\text { urinary tract; fruits carminative and } \\
\text { laxative }\end{array}$ & Perennial & Indigenous & Common & Woodland \\
\hline Rosaceae & Prunus armeniaca & Khubanai & stem & $\begin{array}{l}\text { Gum obtained from stem famed as } \\
\text { anticancer }\end{array}$ & Tree & Cultivated & Common & Arable \\
\hline Rosaceae & Prunus domestica & Alucha & Fruits & Fruit laxative & Tree & Cultivated & Common & Arable \\
\hline Rosaceae & Rosa moschata & Gulab & Flowers & $\begin{array}{l}\text { Decoction of flowers for curing stomach } \\
\text { disorders }\end{array}$ & Shrub & Indigenous & Scattered & Woodland \\
\hline Rosaceae & Spiraea spec. & Krachae & Flowers & Tea from its flowers to ease natal pain & Shrub & Indigenous & Common & Woodland \\
\hline Rutaceae & Skimmia laureola & Nazar pana & Leaves & $\begin{array}{l}\text { Burnt incense to expel evils and evil } \\
\text { eyes; tea for indigestion, smoke } \\
\text { considered as antiseptic }\end{array}$ & Shrub & Indigenous & Common & Woodland \\
\hline Rutaceae & Zanthoxylum armatum & Dambara & Fruit & $\begin{array}{l}\text { Fruits as antipyretic and for treating } \\
\text { stomachache }\end{array}$ & Shrub & Indigenous & Scattered & Woodland \\
\hline Saxifragaceae & Bergenia stracheyi & $\begin{array}{l}\text { The Spinsar } \\
\text { Gat Pana }\end{array}$ & Rhizome & $\begin{array}{l}\text { Powdered rhizome with milk in the } \\
\text { mornings as tonic }\end{array}$ & Perennial & Indigenous & Common & Woodland \\
\hline Simaroubaceae & Ailanthus altissima & Backyanra & bark & $\begin{array}{l}\text { Bark juice mixed with milk to cure } \\
\text { dysentery and diarrhea }\end{array}$ & Tree & $\begin{array}{l}\text { Established } \\
\text { alien }\end{array}$ & Common & Arable \\
\hline Solanaceae & Atropa acuminata & Bargak & leaves & $\begin{array}{l}\text { Poultice of leaves against pain and } \\
\text { rheumatism }\end{array}$ & Perennial & Indigenous & Scattered & Woodland \\
\hline Solanaceae & Capsicum аппиит & Marchakay & Fruits & Carminative & Annual & Cultivated & Common & Arable \\
\hline Solanaceae & Datura stramonium & Batora & $\begin{array}{l}\text { Leaves, } \\
\text { seeds and } \\
\text { flowers }\end{array}$ & $\begin{array}{l}\text { poultice of flowers applied to wounds to } \\
\text { reduce pain; seeds narcotic in nature }\end{array}$ & Annual & Indigenous & Common & Ruderal \\
\hline Solanaceae & Solanum nigrum & Kachmacho & $\begin{array}{l}\text { Leaves and } \\
\text { fruit }\end{array}$ & $\begin{array}{l}\text { Leave paste applied to treat skin } \\
\text { inflammation, fruits against fever }\end{array}$ & Annual & Indigenous & Common & Ruderal \\
\hline Solanaceae & Solanum virginianum & $\begin{array}{l}\text { Marraghona } \\
\mathrm{y}\end{array}$ & Fruit & $\begin{array}{l}\text { Decoction of fruit diuretic and } \\
\text { anthelmintic }\end{array}$ & Perennial & Indigenous & Scattered & Ruderal \\
\hline
\end{tabular}




\begin{tabular}{|c|c|c|c|c|c|c|c|c|}
\hline Plant family & Taxon name & Local name & Parts used & Medicinal uses, remedies & $\begin{array}{l}\text { Growth } \\
\text { form }\end{array}$ & $\begin{array}{l}\text { Plant } \\
\text { status }\end{array}$ & Frequency & Habitat \\
\hline Solanaceae & Withania somnifera & Kotilal & Whole plant & Aphrodisiac & Shrub & Indigenous & Scattered & Ruderal \\
\hline Thymelaeaceae & Daphne mucronata & Laighonai & Fruits, leaves & $\begin{array}{l}\text { Poultice from fruits and leaves against } \\
\text { rheumatism }\end{array}$ & Shrub & Indigenous & Common & Woodland \\
\hline Ulmaceae & Celtis australis & Tagha & Fruits, bark & $\begin{array}{l}\text { Fruits against colic and amenorrhea; } \\
\text { bark decoction as anti-allergic }\end{array}$ & Tree & Indigenous & Scattered & Woodland \\
\hline Urticaceae & Debregeasia saeneb & Ajlai & Leaves & $\begin{array}{l}\text { Fresh ground leaves in paste form for } \\
\text { blistered feet }\end{array}$ & Shrub & Indigenous & Common & Woodland \\
\hline Verbinaceae & Verbena officinalis & Shamakai & Whole plant & Decoction is anti-malarial & Perennial & Indigenous & Common & Ruderal \\
\hline
\end{tabular}


Table 2. List of ethno-medicinal plants applied with different syndromes.

\begin{tabular}{l}
\hline Syndrome category \\
\hline $\begin{array}{l}\text { Gastrointestinal } \\
\text { disorders }\end{array}$ \\
\\
Dermatological and \\
topical diseases
\end{tabular}

Respiratory illness

Skeleto-muscular
problems

Cardio-vascular complaints and circulatory diseases

Fever, headache, analgesic

Urinary complaints

Dental problems

\section{Plants}

Aesculus indica, Ailanthus altissima, Ajuga bracteosa, Allium sativum, Artemisia scoparia, Brassica campestris var. rapa, Bupleurum longicaule, Capsella bursapastoris, Caltha alba, Celtis australis, Capsicum annuum, Chenopodium album, Colchicum luteum, Convolvulus arvensis, Coriandrum sativum, Cynoglossum lanceolatum, Dioscorea deltoidea, Diospyros kaki, Diospyros lotus, Euphorbia wallichii, Foeniculum vulgare, Fragaria bucharica, Heracleum candicans, Hypericum perforatum, Indigofera heterantha, Jasminum humile, Melia azedarach, Mentha spicata, Mentha royleana,Nasturtium officinale, Nepeta cataria, Oxalis corniculata, Pimpinella diversifolia, Plantago major, Platanus orientalis, Polygonatum verticillatum, Prunus domestica, Punica granatum, Ricinus communis, Rosa moschata, Sambucus wightiana, Skimmia laureola, Solanum virginianum, Stellaria media, Viburnum grandiflorum, Zanthoxylum armatum

Abelmoschus esculentus, Allium cepa, Allium sativum, Amaranthus viridis, Brassica campestris, Celtis australis, Convolvulus arvensis, Cuscuta reflexa, Cynodon dactylon, Datura stramonium, Debregeasia saeneb, Echinops echinatus, Euphorbia wallichii, Indigofera heterantha, Jasminum officinale, Juglans regia, Melia azedarach, Onosma hispida, Periploca aphylla, Pistacia chinensis, Plantago lanceolata, Plantago major, Salvia lanata, Sambucus wightiana, Silene vulgaris, Skimmia laureola, Solanum nigrum

Abelmoschus esculentus, Allium cepa, Allium sativum, Amaranthus viridis, Arisaema jacquemontii, Arenaria griffithii, Artemisia scoporia, Delphinium denundatum, Elaeagnus umbellata, Ficus palmata, Geranium wallichianum, Heracleum candicans, Melia azedarach, Morus alba, Papaver somniferum, Ricinus communis.

Aesculus indica, Aconitum violaceum, Atropa acuminata, Colchicum luteum, Daphne mucronata, Lotus corniculatus, Paeonia emodi, Polygonatum verticillatum, Sambucus wightiana, Sarcococca saligna

Ajuga bracteosa, Allium sativum, Colchicum luteum, Cuscuta reflexa, Dioscorea deltoidea, Elaeagnus umbellata, Hedera nepalensis, Otostegia limbata, Pistacia chinensis, Podophyllum hexandrum, Portulaca oleracea, Taraxacum sp.

Cichorium intybus, Delphinium denundatum, Geranium wallichianum, Hypericum perforatum, Jasminum humile, Melia azedarach, Papaver somniferum, Solanum nigrum, Thymus linearis, Verbena officinalis, Xanthium strumarium, Zanthoxylum armatum

Abelmoschus esculentus, Allium cepa, Allium sativum, Capsella bursa-pastoris, Chenopodium album, Cuscuta reflexa, Foeniculum vulgare, Fragaria vesca, Hypericum perforatum, Portulaca oleracea, Quercus oblongata, Quercus floribunda, Solanum virginianum, Taraxacum spec.

Isodon rugosus, Juglans regia, Olea europaea, Origanum vulgare, Otostegia limbata, Rumex dentatus 


\begin{tabular}{|c|c|}
\hline Syndrome category & Plants \\
\hline ENT complaints & $\begin{array}{l}\text { Ajuga bracteosa, Artemisia scoporia, Corydalis stewartii, Origanum vulgare, } \\
\text { Primula denticulata }\end{array}$ \\
\hline $\begin{array}{l}\text { Nerve disorders } \\
\text { (anodyne, epilepsy, } \\
\text { sedative) }\end{array}$ & Ajuga bracteosa,Cannabis sativa \\
\hline $\begin{array}{l}\text { Genital and sexual } \\
\text { diseases }\end{array}$ & $\begin{array}{l}\text { Allium cepa, Allium sativum, Avena sativa, Celtis australis, Colchicum luteum, } \\
\text { Geranium wallichianum, Lotus corniculatus, Polygonatum multiflorum, } \\
\text { Polygonatum verticillatum, Quercus dilatata, Withania somnifera }\end{array}$ \\
\hline $\begin{array}{l}\text { Others (wounds, cuts, } \\
\text { narcotic, tonic, tumor, } \\
\text { anticancer and } \\
\text { stimulant) }\end{array}$ & $\begin{array}{l}\text { Allium cepa, Allium sativum, Avena sativa, Berberis lycium, Bergenia stracheyi, } \\
\text { Cannabis sativa, Capsella bursa-pastoris, Coriandrum sativum, Cynodon dactylon, } \\
\text { Datura stramonium, Juglans regia, Lathyrus aphaca, Paeonia emodi, Papaver } \\
\text { somniferum, Periploca aphylla, Prunus armeniaca, Salvia moorcroftiana, } \\
\text { Taraxacum sp. }\end{array}$ \\
\hline Delivery & Spiraea sp. \\
\hline
\end{tabular}

\section{Competing interests}

The authors declare that they have no competing interests.

\section{Authors' contributions}

NA carried out the field work, analyzed the data and drafted the manuscript. EB revised the whole manuscript and contributed to the editing and interpreting of the data. AR conceptualized and designed the study while WM helped in the initial drafting of the manuscript. All authors read and approved the final manuscript.

\section{Acknowledgements}

This research was funded by HEC (Higher Education Commission of Pakistan) under the Faculty Development Program of the Islamia College University Peshawar, Pakistan.We are indebted to all villagers, guides and informants who shared their knowledge with us. 


\section{References}

Abbasi, Arshad Mehmood, Khan, Mir Ajab, Ahmad, Mushtaq, and Zafar, Muhammad. 2011. Medicinal Plant Biodiversity of Lesser Himalayas-Pakistan. Springer.

Abbasi,A.M., Khan,M.A., Ahmad,M., Zafar,M., Khan,H., Muhammad,N., Sultana,S., 2009. Medicinal plants used for the treatment of jaundice and hepatitis based on socio-economic documentation. African Journal of Biotechnology 8, 1643-1650.

Adnan,M., Begum,S., Khan,A.L., Tareen,A.M., Lee,I.J., 2012. Medicinal plants and their uses in selected temperate zones of Pakistani Hindukush-Himalaya. Journal of medicinal plants research 6, 4113-4127.

Adnan,M., Hölscher,D., 2010. Medicinal plant abundance in degraded and reforested sites in Northwest Pakistan. Mountain Research and Development 30, 25-32.

Adnan,S.M., Ashiq,A.K., Latif,A., Shinwari,Z.K., 2006. Threats to the sustainability of EthnoMedicinal uses in Northern Pakistan (A Case Study of Miandam Valley, District Swat, NWFP Province, Pakistan). Lyonia 11, 91-100.

Ali,H., Qaiser,M., 2009. The ethnobotany of Chitral valley, Pakistan with particular reference to medicinal plants. Pakistan Journal of Botany 41, 2009-2041.

Ali,H., Sannai,J., Sher,H., Rashid,A., 2011. Ethnobotanical profile of some plant resources in Malam Jabba valley of Swat, Pakistan. Journal of medicinal plants research 5, 4676-4687.

Ali,S.I., Qaiser,M.. Flora of Pakistan. 1993. University of Karachi,Pakistan.

Awan,M.R., Iqbal,Z., Shah,S.M., Jamal,Z., Jan,G., Afzal,M., Majid,A., Gul,A., 2011. Studies on traditional knowledge of economically important plants of Kaghan Valley, Mansehra District, Pakistan. Journal of medicinal plants research 5, 3958-3967.

Badshah,L., Hussain,F., 2011. People preferences and use of local medicinal flora in District Tank, Pakistan. Journal of medicinal plants research 5, 22-29. 
Bako,S.P., Bakfur,M.J., John,I., Bala,E.I., 2005. Ethnomedicinal and Phytochemical Profile of Some Savanna Plant Species in Nigeria. International Journal of Botany 1, 147-150.

Bhat,J.A., Kumar,M., Bussmann,R.W., 2013. Ecological status and traditional knowledge of medicinal plants in Kedarnath Wildlife Sanctuary of Garhwal Himalaya India. Journal of Ethnobiology and Ethnomedicine 9.

Eberhardt,E., Dickoré,W.B., Miehe,G., 2007. Vegetation map of the Batura Valley (Hunza Karakorum, North Pakistan). Erdkunde 61, 93-112.

Hamayun,M., Khan,S.A., Sohn,E.Y., Lee,I.J., 2006. Folk medicinal knowledge and conservation status of some economically valued medicinal plants of District Swat, Pakistan. Lyonia 11, 101-113.

Hazrat,A., Shah,J., Ahmad,S., Nisar,M., Jan,A., Sikandar, 2010. Medicinal plants of Usherai valley, Dir, NWFP, Pakistan. Pakistan Journal of Botany 42, 31-34.

Hussain,F., Sher,H., Ibrar,M., Durrani,M.J., 2005. Ethnomedicinal uses of plants of District Swat, Pakistan. Pakistan Journal of Plant Sciences 11, 137-158.

Hussain,F., Shah,S.M., Sher,H., 2007. Traditional resource evaluation of some plants of Mastuj, District Chitral, Pakistan. Pakistan Journal of Botany 39, 339-354.

Ibrar,M., Hussain,F., Sultan,A., 2007. Ethnobotanical studies on plant resources of Ranyal hills, District Shangla, Pakistan. Pakistan Journal of Botany 39, 329-337.

Iqbal,H., Sher,Z., 2011. Medicinal plants from salt range, Pind Dadan Khan, District Jhelum, Punjab, Pakistan. Journal of medicinal plants research 5, 2157-2168.

Jabeen,A., Khan,M.A., Ahmad,M., Zafar,M., Ahmad,F., 2009. Indigenous uses of economically important flora of Margallah hills national park, Islamabad, Pakistan. African Journal of Biotechnology 8, 763-784. 
Jan,G., Khan,M.A., Farhatullah,J.F.G., Ahmad,M., Jan,M., Zafar,M., 2011. Ethnobotanical studies on some useful plants of Dir Kohistan valleys, KPK, Pakistan. Pakistan Journal of Botany $43,1849-1852$.

Kala,C.P., 2005. Ethnomedicinal botany of the Apatani in the Eastern Himalayan region of India. Journal of Ethnobiology and Ethnomedicine 1, 11.

Khan,M., Musharaf,S., Shinwari,Z.K., 2011. Ethnobotanical importance of halophytes of Noshpho salts mine, District Karak, Pakistan. Research in Pharmaceutical Biotechnology 3, 46-52.

Khan,S.M., Page,S., Ahmad,H., Shaheen,H., Ullah,Z., Ahmad,M., Harper,D.M., 2013. Medicinal flora and ethnoecological knowledge in the Naran Valley, Western Himalaya, Pakistan. Journal of Ethnobiology and Ethnomedicine 9.

Khan,S.W., Khatoon,S., 2008. Ethnobotanical studies on some useful herbs of Haramosh and Bugrote valleys in Gilgit, northern areas of Pakistan. Pakistan Journal of Botany 40, 43-58.

Mahmood,A., Qureshi,R.A., Mahmood,A., Sangi,Y., Shaheen,H., Ahmad,I., Nawaz,Z., 2011. Ethnobotanical survey of common medicinal plants used by people of District Mirpur, AJK, Pakistan. Journal of medicinal plants research 5, 4493-4498.

Murad,W., Ahmad,A., Gilani,S.A., Khan,M.A., 2011. Indigenous knowledge and folk use of medicinal plants by the tribal communities of Hazar Nao Forest, Malakand District, North Pakistan. Journal of medicinal plants research 5, 1072-1086.

Muthu,C., Ayyanar,M., Raja,N., Ignacimuthu,S., 2006. Medicinal plants used by traditional healers in Kancheepuram district of Tamil Nadu, India. Journal of Ethnobiology and Ethnomedicine 2, 43-53.

Nasir, E. and Ali, S. I.1982. Flora of Pakistan. University of Karachi,Pakistan.

Nasir, Eugene and Ali, S. I.1970. Flora of West Pakistan. University of Karachi,Pakistan.

Nasir, Eugene, Ali, S. I., and Stewart, R. R.1972. Flora of West Pakistan: an annotated catalogue of the vascular plants of West Pakistan and Kashmir. Fakhri printing press Karachi, Pakistan. 
Nüsser,M., Dickoré,W.B., 2002. A tangle in the triangle: vegetation map of the eastern Hindukush (Chitral, northern Pakistan). Erdkunde 56, 37-59.

Okello,J., Ssegawa,P., 2007. Medicinal plants used by communities of Ngai Subcounty, Apac District, northern Uganda. African Journal of Ecology 45, 76-83.

Pieroni,A., Sheikh,Q.Z., Ali,W., Torry,B., 2008. Traditional medicines used by Pakistani migrants from Mirpur living in Bradford, Northern England. Complementary Therapies in Medicine $16,81-86$.

Porter,S.C., 1970. Quaternary glacial record in Swat Kohistan, west Pakistan. Geological Society of America Bulletin 81, 1421-1446.

Rabbi,F., Bauer,S., Idalinya,J., 2010. Contribution of forests to rural inequality reduction: present scope and future options for rural development and sustainable use of forests. International Journal of Sustainable Development and World Ecology 17, 4-14.

Rashid,M.. Resource management plan for Swat Forest Range of Swat Forest Division. 1999. Forest Management Center NWFP, Forest Department and Intercooperation SDC: Government of Switzerland.

Razaq,A., Rashid,A., Ali,H., Ahmad,H., Islam,M., 2010. Ethnomedicinal potential of plants of Changa Valley District, Shangla, Pakistan. Pakistan Journal of Botany 42, 3463-3475.

Sher,H., Hussain,F., Sher,H., 2010. Ex-situ management study of some high value medicinal plant species in Swat, Pakistan. Ethnobotany Research \& Applications 8, 17-24.

Sher,H., Hussain,F., 2009. Ethnobotanical evaluation of some plant resources in Northern part of Pakistan. African Journal of Biotechnology 8, 4066-4076.

Sher,H., Hussain,S.K.. Ecological survey and rapid vulnerability assessment of medicinal and aromatic plants of Miandam,Pakistan. 2007. WWF,Pakistan.

Ref Type: Report

Sher,Z., Khan,Z., Hussain,F., 2011. Ethnobotanical studies of some plants of Chagharzai valley, District Buner, Pakistan. Pakistan Journal of Botany 43, 1445-1452. 
Shinwari, Z. K., Rehman, M., Watanabe, T., and Yoshikawa, Y.2006. Medicinal and aromatic plants of Pakistan (a pictorial guide). Kohat University of Science and Technology, Kohat, Pakistan.

Shinwari,Z.K., 2010. Medicinal plants research in Pakistan. Journal of medicinal plants research 4, $161-176$.

Shinwari,Z.K., Gilani,S.S., 2003. Sustainable harvest of medicinal plants at Bulashbar Nullah, Astore (Northern Pakistan). Journal of Ethnopharmacology 84, 289-298.

Teklehaymanot,T., Giday,M., 2007. Ethnobotanical study of medicinal plants used by people in Zegie Peninsula, Northwestern Ethiopia. Journal of Ethnobiology and Ethnomedicine 3, 1221.

World Health Organization, 2002. Traditional medicine-growing needs and potential. WHO policy perspectives on medicine, No. 2.

Yineger,H., Kelbessa,E., Bekele,T., Lulekal,E., 2008. Plants used in traditional management of human ailments at Bale Mountains National Park, Southeastern Ethiopia. Journal of medicinal plants research 2, 132-153. 


\title{
CHAPTER 3
}

\section{VEGETATION PATTERNS AND HUMAN IMPACT ALONG AN ELEVATION GRADIENT IN THE MOUNTAINS OF SWAT, NORTHERN PAKISTAN}

\author{
Naveed Akhtar ${ }^{\mathrm{a}, \mathrm{b}}$ and Erwin Bergmeier ${ }^{\mathrm{b}}$ \\ ${ }^{a}$ Department of Botany, Islamia College, Peshawar, 25000, Pakistan \\ ${ }^{\mathrm{b}}$ Department of Vegetation Analysis and Phytodiversity, Albrecht von Haller Institute of Plant \\ Sciences, Georg August University, 37073 Göttingen, Germany \\ Corresponding author \\ Naveed Akhtar \\ eMail: naveedakhter75@yahoo.com \\ Phone: +92-300-5997454 \\ Erwin Bergmeier \\ eMail: erwin.bergmeier@bio.uni-goettingen.de \\ Phone: +49-551-39-5700
}




\begin{abstract}
The distribution of the woodland vegetation in the mountains of Miandam, Swat, North Pakistan, has been studied along an elevation gradient between 1600-3400 m. A data set of four hundred relevés was classified using Roleček’s modified TWINSPAN with Sørensen dissimilarity distance measure. Twelve plant communities corresponding to six elevational zones were established and a georeferenced distribution map is presented. Indicator plant communities related to elevational zones (Alpine, Subalpine, Boreal, Upper Nemoral, Lower Nemoral, Meridional) include: Alpine turf of Sibbaldia cuneata with Juniperus patches; Subalpine scrub of Betula utilis; Subalpine BetulaViburnum treeline scrub; Laurophyllous Quercus semecarpifolia forest; Coniferous Picea smithiana forest; Woodland of Abies pindrow and Viburnum grandiflorum; Woodland of Abies pindrow and Indigofera heterantha; Mixed forest of Quercus floribunda and Pinus wallichiana; Coniferous forest of Abies pindrow and Geranium wallichianum; Woodland of Pinus wallichiana and Sorbaria tomentosa shrubbery; Woodland of Pinus wallichiana and Indigofera heterantha scrub; Sub-tropical groves of Ailanthus altissima. Detrended Correspondence Analysis (DCA) results suggest that elevation is the main explaining factor in the data set. Vascular plant species found comprise 33 trees, 52 shrubs, 11 climbers, and 305 herbaceous plants. A comparison of the vegetation of Miandam with other studies based on dominant forest plants revealed most similarities towards south east, specifically with the vegetation of Ayubia National Park (Abbotabad) and the Bagh district in Kashmir. Our assessment of human impact on the vegetation revealed overgrazing, logging, and locally overcollection of medicinal plants as the most severe threats to woodland ecosystems. We recommend that local and national governments and specifically forest authorities urgently increase their efforts to stop illegal wood cutting and logging.
\end{abstract}

Key words: forest vegetation, georeferencing, vegetation zonation, vegetation classification, woodland 


\section{Introduction}

Sitting astride one of the major biogeographical disjunctions of southern Asia, Pakistan's flora and vegetation are highly diverse. Takhtajan et al. (1986) delineated five floristic provinces extending into the territory of Pakistan. Two of these, the Southern Iranian Province and the Sindian Province, belong to the paleotropical Sudano-Zambezian Region. The other three floristic provinces belong to the Holarctic Irano-Turanian Region. Of these provinces, Northern Baluchistan and the Western Himalayas form part of the Western Asiatic Subregion, while the Tibetan Province belongs to the Central Asiatic Subregion. The Western Himalayan Province is of particular interest as "the flora of this province occupies a kind of transitional position and is a link between the ancient Mediterranean (Tethyan) and eastern Asiatic floras" (Takhtajan et al. 1986). Recent studies on the phytogeography, biodiversity and phytosociology in Pakistan and the Western Himalayan Province have been provided by Ahmed and Mahmood (1998), Chawla et al.(2008), Dickoré and Nüsser (2000), Eberhardt et al. (2007), Khan (2012), Malik and Hussain (2006), Nüsser and Dickoré (2002), Peer et al. (2007), Saima et al. (2009) and Shaheen et al. (2011).

About $40 \%$ of Pakistan's natural forests are located in its northern province of Khyber Pakhtunkhwa, with almost $17 \%$ of the total area of this province being wooded (Ahmed and Mahmood, 1998). Most of the natural woodlands in Khyber Pakhtunkhwa are located in the mountainous districts of Chitral, Upper Dir, Lower Dir, Swat, Shangla, Malakand, Buner, Kohistan, Battagram, Mansehra, Abbottabad and Haripur. In the district of Swat and surrounding areas, several studies contributed to the knowledge of woodland types from subtropical levels to the high mountains, e.g. Ahmed et al. (2010), Beg and Khan (1984), Hussain et al. (1992), Hussain et al.(1995), Khan (2012), Rashid et al.(2011) and Sher and Al yemeni (2011). Ilyas et al. (2012) assessed the vegetation structure and composition in the Qalagai hills, Swat, aiming to pinpoint strategies for the conservation of the threatened forest ecosystems in that area. Recently Khan et al. (2013) identified plant communities in the Western Himalayas using multivariate approaches.

In the present study we examined the variation in vascular plant species composition along an elevation gradient in the mountains of Swat, North Pakistan, combining multivariate classification and ordination. Our objectives were (1) to survey and describe woodlands and shrublands in the area of Miandam, (2) to identify the vegetation zones and to reveal similarities with zonal plant communities described from the wider surroundings and (3) to point out human impacts and assess risks for the plant communities. 


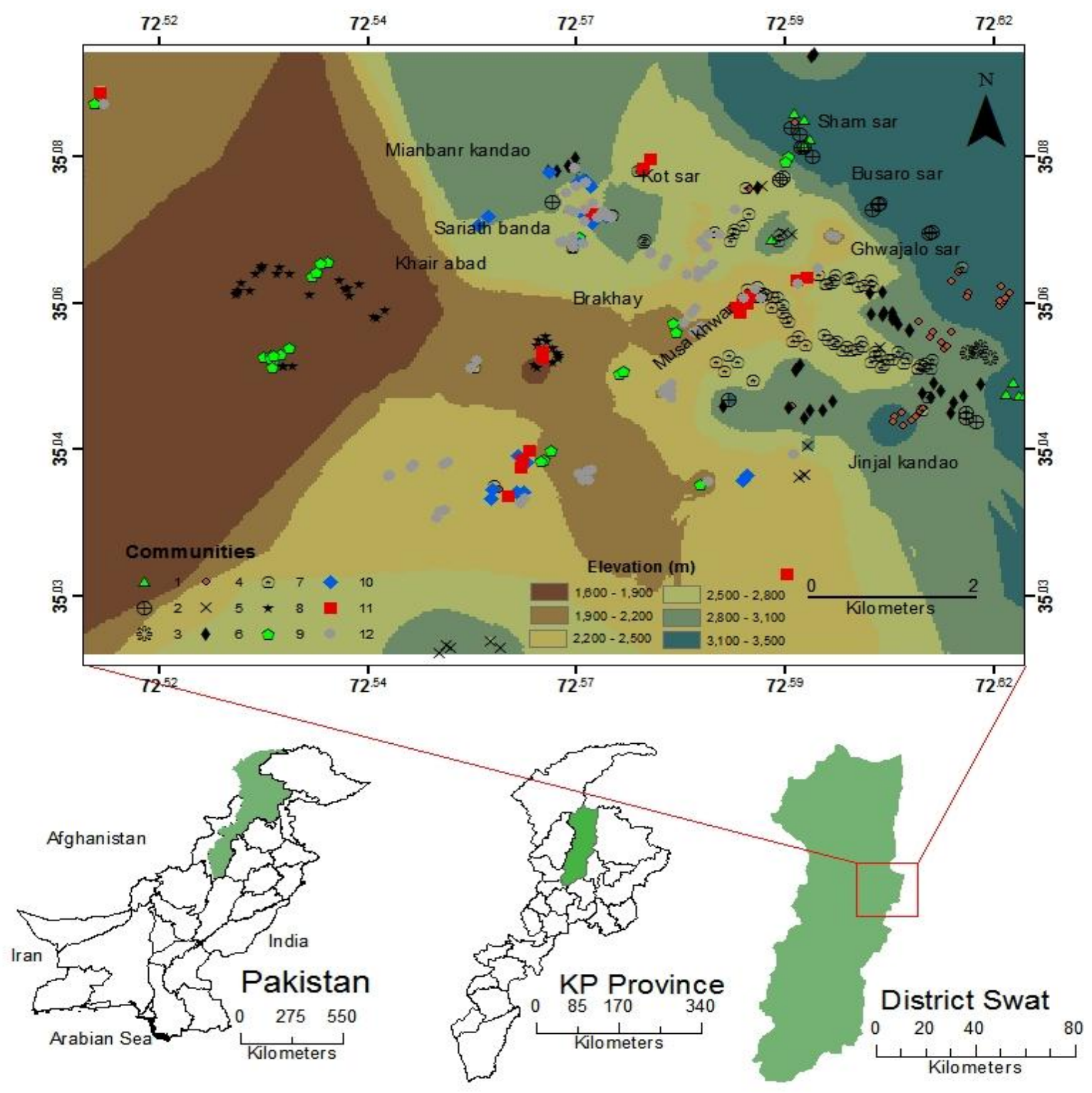

Figure 1. A georeferenced map of the study area of Miandam showing plant communities, localities and elevation zones. Plant community numbers refer to the communities described in the text.

\section{Study Area}

The study area of Miandam ( $\left.35^{\circ} 1^{\prime}-5^{\prime} \mathrm{N}, 72^{\circ} 30^{\prime}-37^{\prime} \mathrm{E}\right)$ is located in the District of Swat in the Province of Khyber Pakhtunkhwa (formerly North West Frontier Province). The province is located 
on both banks of the river Indus and is bounded by the Himalaya, Karakoram and Hindukush Mountains in the north and Afghanistan in the north-west. The District of Swat is located in the north of Khyber Pakhtunkhwa (Figure 1). Miandam lies about $50 \mathrm{~km}$ northeast of Saidu Sharif, district capital of Swat, and $21 \mathrm{~km}$ from Khwazakhela, administrative centre of the surrounding villages. Its western boundary is the river Swat. The narrow valley of Miandam is surrounded on the north, east and south by high mountains. It ranges between 1400 to $3400 \mathrm{~m}$.

According to Zahid and Rasul (2011), and based on Thornthwaite's index of thermal efficiency, the research area falls in the "Mild microthermal" zone. The average annual rainfall is $1038 \mathrm{~mm}$ (Saeeda, 2005). March, July and August are months with heavy rainfall (New et al. 2002). December and January are the coldest months with temperatures down to a mean minimum of $-10^{\circ} \mathrm{C}$ (Saeeda, 2005).

The Swat valley and adjoining parts of NW Pakistan consist of rock units representing the Kohistan Arc sequence, the Tethys oceanic lithosphere and the Indo-Pakistan plate sequence. The Kohistan Arc sequence consists essentially of late Jurassic-Cretaceous and Tertiary plutonic and metamorphic plutonic, volcanic and sedimentary rocks (Arif et al. 2011).The geology of the study area is dominated by a group of plutonic rocks, the Upper Swat Hornblendic Group, forming a broad northeast-trending belt which includes granite, granodiorite, syenite, diorite, gabbro, and associated pegmatites (Porter, 1970).

The lower zone of Miandam between 1500-1800 m is covered by terraced crop fields with scattered groups of trees. Maize is the most important cash crop followed by potato and turnip. Wheat is also cultivated in lower areas. Most areas above $1800 \mathrm{~m}$ up to $3300 \mathrm{~m}$ are wooded. The elevation range in our study was between $1600 \mathrm{~m}$ and $3400 \mathrm{~m}$.

\section{Materials and methods}

\section{Data collection}

Field work was carried out by one of us (NA) in 2010-2012, from May through September. Four hundred vegetation relevés of $10 \mathrm{~m} \times 10 \mathrm{~m}$ were preferentially placed in stratified wooded and sparsely wooded areas, yet limited by accessibility. Minimum distance between relevés of the same formation was approximately $50 \mathrm{~m}$. Cover/abundance of vascular plants was estimated using the Braun-Blanquet scale (e.g. Dierschke, 1994). Slope, aspect and other abiotic parameters, further tree, shrub and herb cover, height of the highest and lowest trees and shrubs and tree diameters of old 
trees were also assessed. As geological maps were not available we did not identify bedrock types per relevé. Coordinates (WGS 84) and elevation were measured using GPS device. Plant samples were collected of almost all vascular plant species and identified using Ali and Qaisar (2001), Breckle et al. (2010) and Urrahman (2012). Herbarium collections of the Botanische Staatssammlung München (M), Germany, were consulted. The assessment of human impact and threat was based on NA's extensive field observations.

\section{Data analysis}

Species, structural and environmental data of all relevés were entered in a Turboveg database (Hennekens and Schaminée, 2001). The relevés were classified using TWINSPAN (Roleček et al. 2009) under JUICE 7.0 (Tichý, 2002). In the first data set arbitrarily 15 groups were established. Three outlier groups of non-woody vegetation were excluded from further analysis. The remaining 12 groups comprising 387 relevés were found to be interpretable and subjected to further analyses. We used phi coefficient as species fidelity measure. Fisher's exact test was applied and zero fidelity value was given to the species with significance value of $P>0.01$. Diagnostic, constant and dominant species (Chytrý et al. 2002) were determined using threshold values of fidelity $(\Phi$ coefficient) $35 \%$, frequency $40 \%$, and cover $30 \%$. Sørensen dissimilarity with Average linkage was used for clustering and Detrended Correspondence Analysis (DCA) (Ter Braak and Šmilauer, 2002) to measure the principal gradient length and to relate species composition to environmental variables. 


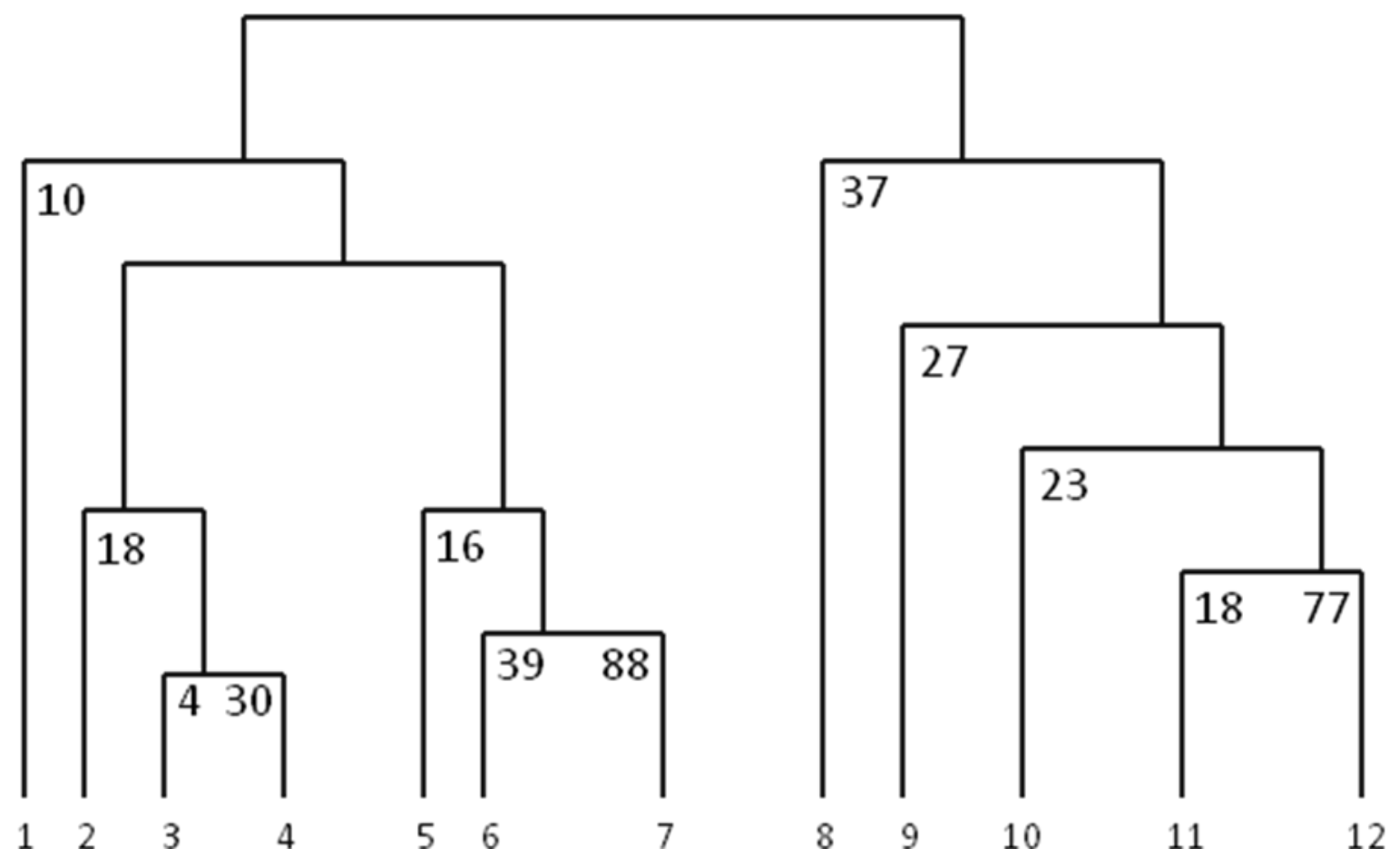

Figure 2. TWINSPAN (modified after Roleček et al. 2009) classification hierarchy based on 387 relevés collected in Miandam, Swat, North Pakistan. The numbers of the 12 units correspond to the plant communities described in the text. In the corners numbers of relevés in each group are indicated.

A second DCA was performed on a data set restricted to Abies and Picea woodlands. Elevation (m), aspect, slope (degrees), cover of litter (\%) and rocks (\%), longitude and latitude were used as environmental variables. Aspect is a circular variable and the values were transformed from degrees to radians then converted to cosine, i.e to a range of -1 to +1 , with aspects close to -1 being southward and those close to +1 , northward. Environmental variables were checked for multicollinearity based on variance inflation factor. Longitude was omitted from analysis as it increased along with increasing elevation. A georeferenced map was prepared using ArcGIS version 10.1 to show the distribution of the plant communities (Figure 1). The allocation of plant communities to vegetation belts corresponds to the terms and zonation outlined by Schroeder (1998). Plant nomenclature follows the Pakistan Plant Database (www.tropicos.org/Project/Pakistan) except Quercus oblongata, Quercus floribunda, Leptopus cordifolius, Wulfeniopsis amherstiana, Acomastylis elata, Isodon rugosus and Fragaria bucharica, for which we preferred The Plant list (www.theplantlist.org). 


\section{Results}

\section{Diversity, classification and description of vegetation}

The vegetation data set of 387 relevés comprised 401 species, including 33 trees, 52 shrubs, 11 climber and 305 herb species. Modified TWINSPAN suggested 12 sufficiently distinct and interpretable vegetation units (Table 1). At the first hierarchy level the data set was separated in two distinct groups based on species composition (Figure 2). The two groups differ also in altitudinal distribution. The units 1-7 are communities of high elevation chiefly beyond $2400 \mathrm{~m}$ while the other units 8-12 comprise communities mainly below $2400 \mathrm{~m}$. At the next level unit 1 is separated as humid scrub of Betula, unit 2 as forest of Quercus semecarpifolia, units 3 and 4 represent subalpine tree line scrub and alpine Juniperus patches, respectively. At the other branch of the dendrogram unit 8 is representative of the meridional zone. Units 9-10 represent the lower nemoral and units 11 and 12 the upper nemoral zone.

Together with a brief description of each vegetation unit, we indicated all kinds of local human impact and possibly resulting threats to the ecosystems. Cover values of bedrock, tree and shrub layers, and height of trees and shrubs are given as mean and, in brackets, maximum values.

(1) Subalpine scrub of Betula utilis

Elevation range: 3100-3200 m, chiefly encountered at Ghwajalo sar (Figure 1)

Bedrock cover: $8(-20) \%$

Trees: Betula utilis, 5.9(-15) $\mathrm{m}$

Shrubs: Salix sp. (unident.), 15(-38) \%; 0.8(-2.5) m

Diagnostic species: Arenaria griffithii, Pleurospermum candollei, Potentilla atrosanguinea, Ranunculus (unident.), Salix (unident.), Phacelurus speciosus, Poa sp.

Constant species: Betula utilis, Arenaria griffithii, Phacelurus speciosus, Pleurospermum candollei, Poa sp., Potentilla atrosanguinea, Ranunculus (unident.), Salix (unident.),

Dominant species: Poa cf. pratensis,

Mean number of species $( \pm \mathrm{SD}): 6.4 \pm 1.7$

Human impact and threat: The local herders take cows, sheep and buffaloes for summer grazing to the alpine pastures of Sham sar, resulting in local overgrazing and trampling close to temporary shelters 
Table 1. Synoptic table of 12 vegetation units, classified from 387 relevés, subjected to modified TWINSPAN analysis, of Miandam, Swat, Northern Pakistan, with percentage frequencies and fidelities (phi coefficient; italic indices). Frequencies of $50 \%$ or higher are shown as bold figures. Fisher's exact test was applied and zero fidelity value was given to the species with significance value of $P>0.01$. Only species with frequency values of $20 \%$ or more in at least one column are shown. Plant community numbers correspond to numbers of vegetation units in the text. Table sectors for trees, shrubs and herbs, respectively, are separated by simple lines. (1) Subalpine scrub of Betula utilis; (2) Laurophyllous Quercus semecarpifolia forest; (3) Subalpine Betula-Viburnum treeline scrub; (4) Alpine turf of Sibbaldia cuneata with Juniperus patches; (5) Coniferous forest of Abies pindrow and Geranium wallichianum; (6) Coniferous Picea smithiana forest; (7) Woodland of Abies pindrow and Viburnum grandiflorum; (8) Sub-tropical groves of Ailanthus altissima; (9) Mixed forest of Quercus floribunda and Pinus wallichiana; (10) Woodland of Abies pindrow and Indigofera heterantha; (11) Woodland of Pinus wallichiana and Sorbaria tomentosa shrubbery; (12) Woodland of Pinus wallichiana and Indigofera heterantha scrub.

\begin{tabular}{|c|c|c|c|c|c|c|c|c|c|c|c|c|c|c|c|c|c|c|}
\hline Communities & 1 & & 2 & & 3 & 4 & & 5 & 6 & & 7 & 8 & & 9 & 10 & & 11 & 12 \\
\hline No. of relevés & 10 & & 18 & & 4 & 30 & & 16 & 39 & & 88 & 37 & & 27 & 23 & & 18 & 77 \\
\hline$\overline{\overline{\text { Betula utilis }}}$ & & 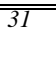 & - & & $2 \mathbf{5 0}^{32}$ & . & & - & 8 & . & . & . & & . & . & & . & . \\
\hline Quercus semecarpifolia & . & & 67 & 61 & . & . & & 12 & 3 & & . & . & & . & . & & . & . \\
\hline Picea smithiana & . & & 56 & 20 & . & 13 & & 12 & 79 & 50 & 22 & . & & . & 4 & & . & 14 \\
\hline Abies pindrow & . & & . & & . & 7 & & $100^{27}$ & 59 & 15 & $84^{53}$ & . & & . & 78 & 21 & . & 17 \\
\hline Taxus wallichiana & . & & . & & . & 10 & & 6 & 51 & 572 & 2 & . & & . & . & & . & . \\
\hline Prunus cornuta & . & & . & & . & . & & . & 5 & & 16 & . & & . & 38 & 28 & 11 & 12 \\
\hline Aesculus indica & . & & . & & . & . & & . & 5 & & $27^{26}$ & . & & . & 4 & & . & 6 \\
\hline Rhamnus purpurea & . & & . & & . & . & & . & 3 & & 2123 & . & & . & . & & . & 4 \\
\hline Ailanthus altissima & . & & . & & . & . & & . & . & & . & 62 & 71 & . & . & & 11 & . \\
\hline Olea ferruginea & . & & . & & . & . & & . & . & 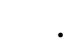 & . & 35 & 36 & 11 & . & & 13 & . \\
\hline Robinia pseudo-acacia & . & & . & & . & . & & . & . & . & . & 27 & 37 & . & . & & 6 & . \\
\hline Ficus palmata & . & & . & & . & . & & . & . & & . & 27 & 30 & 9 & . & & 11 & 3 \\
\hline Celtis caucasica & . & & . & & . & . & & . & . & . & . & 22 & 33 & . & 4 & & . & 1 \\
\hline Quercus floribunda & . & & 17 & & . & . & & 12 & 5 & & 2 & . & & 8166 & . & & . & 9 \\
\hline Pinus wallichiana & . & & . & & . & 17 & & . & . & & 26 & 8 & & 6720 & 22 & & 28 & 87 \\
\hline Pyrus pashia & . & & . & & . & . & & . & . & & . & 8 & & 2236 & . & & . & . \\
\hline Ficus species & . & & . & & . & . & & . & . & & . & . & & 2130 & . & & . & . \\
\hline Quercus oblongata & . & & 11 & & . & . & & . & . & & . & . & & 4 & . & & . & 27 \\
\hline Salix spec. & 40 & & . & & . & . & & . & 5 & & . & . & & . & . & & . & . \\
\hline Rhododendron hypenanthum & . & & 21 & 33 & . & . & & . & . & & . & . & & . & . & & . & . \\
\hline Viburnum grandiflorum & . & & . & & $\mathbf{5 0}^{15}$ & 10 & & 19 & 56 & 19 & $69^{46}$ & . & & 22 & 23 & & . & 14 \\
\hline Juniperus communis & . & & . & & . & 33 & 25 & . & . & & . & . & & . & . & & . & . \\
\hline Berberis calliobotrys & . & & . & & . & 23 & 19 & . & 5 & & . & . & & . & . & & 11 & 5 \\
\hline Juniperus squamata & . & & . & & . & 20 & 21 & . & . & & . & . & & . & . & & . & . \\
\hline Viburnum cotinifolium & . & & . & & . & 10 & & 10 & . & & 11 & . & & 4 & 43 & 28 & . & 12 \\
\hline Rubus ulmifolius & . & & . & & . & . & & . & . & & . & . & & 4 & 4 & & $28^{35}$ & 4 \\
\hline Sorbaria tomentosa & . & & . & & . & . & & . & 5 & & 12 & 8 & & . & 28 & 15 & 8940 & 29 \\
\hline Indigofera heterantha & . & & . & & . & . & & 21 & . & & 2 & 12 & & $74^{21}$ & 87 & 26 & $7^{19}$ & 92 \\
\hline Parrotiopsis jacquemontiana & . & & . & & . & . & & . & 10 & & 1 & . & & 14 & 13 & & . & 43 \\
\hline Euonymus hamiltonianus & . & & . & & . & . & & . & . & & · & . & & . & 4 & & $21^{26}$ & . \\
\hline & & & & & & & & & & & & & & & & & Page | & 57 \\
\hline
\end{tabular}




\begin{tabular}{|c|c|c|c|c|c|c|c|c|c|c|c|c|c|c|c|c|c|c|}
\hline Communities & 1 & & 2 & & 3 & 4 & & 5 & 6 & & 7 & 8 & 8 & 9 & & 10 & 11 & 12 \\
\hline Sarcococca saligna & . & & . & & . & . & & . & . & & . & & $16^{16}$ & 54 & 49 & 4 & . & 1 \\
\hline Isodon rugosus & . & & . & & . & . & & . & . & & 8 & & 6228 & 52 & 27 & 9 & $33^{12}$ & 48 \\
\hline Berberis lycium & . & & . & & . & 7 & & . & 5 & & 3 & & 5727 & 63 & 30 & 22 & 17 & 29 \\
\hline Rubus fruticosus & . & & . & & . & . & & . & . & & . & & 2438 & . & & . & . & . \\
\hline Sageretia thea & . & & . & & . & . & & . & . & & . & & 2227 & 19 & 21 & 9 & . & . \\
\hline Cotoneaster microphyllus & . & & . & & . & . & & . & . & & . & & $16^{16}$ & 30 & 29 & 4 & . & 5 \\
\hline Spiraea sp. & . & & . & & . & . & & . & . & & 5 & 3 & 3 & 12 & & 9 & 11 & 31 \\
\hline Jasminum humile & . & & . & & . & . & & 6 & . & & . & . & . & . & & 11 & 6 & 21 \\
\hline Desmodium elegans & . & & . & & . & . & & . & . & & . & & 11 & 25 & 28 & . & 10 & 14 \\
\hline Cestrum nocturnum & . & & . & & . & . & & . & . & & . & . & 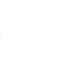 & 21 & 30 & . & . & . \\
\hline Elaeagnus umbellata & . & & . & & . & . & & . & . & & . & . & 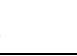 & 21 & 30 & . & . & . \\
\hline Arenaria griffithii & 60 & 77 & . & & . & . & & . & . & & . & . & 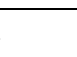 & . & & . & . & . \\
\hline Potentilla atrosanguinea & 60 & 77 & . & & . & . & & . & . & & . & . & 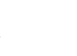 & . & & . & . & . \\
\hline Ranunculus spec. & 60 & 42 & 11 & & . & 17 & 16 & . & 8 & & 3 & . & 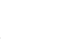 & . & & . & . & . \\
\hline Trifolium repens & $\mathbf{5 0}$ & 23 & . & & . & 20 & & . & 5 & & 14 & & 11 & . & & . & 28 & 3 \\
\hline Pleurospermum candollei & 40 & 45 & . & & . & . & & . & . & & . & . & 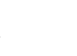 & . & & . & . & . \\
\hline Poa cf. pratensis & 40 & 37 & 6 & & . & 17 & 24 & . & . & & . & . & 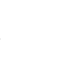 & . & & . & . & . \\
\hline Primula rosea & 40 & 24 & . & & . & 27 & 16 & . & 26 & 19 & . & . & 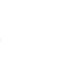 & . & & . & . & . \\
\hline Anemone obtusiloba & 35 & 27 & . & & . & . & & . & . & & 3 & . & 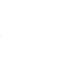 & . & & . & . & . \\
\hline Phacelurus speciosus & 35 & 36 & . & & . & . & & . & . & & . & . & & . & & . & . & . \\
\hline Primula denticulata & . & & $67^{4}$ & 46 & . & 13 & & . & 36 & 33 & 3 & . & 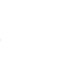 & . & & . & . & . \\
\hline Impatiens brachycentra & . & & 33 & 46 & . & . & & . & 5 & & 1 & . & 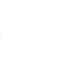 & . & & . & . & . \\
\hline Arisaema flavum & 10 & & $28^{1}$ & 17 & . & 11 & & 12 & . & & 9 & . & 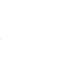 & . & & . & . & 10 \\
\hline Inula grandiflora & . & & $27^{4}$ & 40 & & . & & . & . & & . & . & 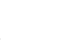 & . & & . & . & . \\
\hline Cypripedium cordigerum & . & & 27 & 40 & . & . & & . & . & & . & . & 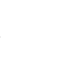 & . & & . & . & . \\
\hline Potentilla curviseta & . & & $27^{2}$ & 25 & . & 7 & & . & . & & 2 & . & 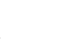 & . & & . & . & . \\
\hline Arum jacquemontii & . & & . & & $100^{100}$ & & & . & . & & . & . & & . & & . & . & . \\
\hline Bistorta amplexicaulis & 30 & 15 & $37^{2}$ & 24 & $100^{50}$ & 20 & & . & 15 & & 7 & 8 & 8 & 17 & & 4 & 18 & 15 \\
\hline Aconitum heterophyllum & . & & . & & $100^{81}$ & 7 & & . & . & & . & . & 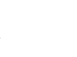 & . & & . & . & . \\
\hline Swertia petiolata & . & & . & & $100^{81}$ & 7 & & . & . & & . & . & 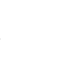 & . & & . & . & . \\
\hline Arisaema utile & . & & . & & $100^{41}$ & 7 & & . & 3 & & $12^{1}$ & o. & 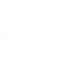 & . & & . & . & 4 \\
\hline Artemisia dubia & . & & . & & $100^{37}$ & 7 & & . & . & & . & 3 & 3 & . & & 7 & 6 & 18 \\
\hline Salvia lanata & . & & . & & $100^{75}$ & . & & 6 & . & & 1 & . & 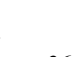 & . & & . & . & 1 \\
\hline Origanum vulgare & . & & 6 & & $100^{28}$ & 33 & 20 & 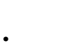 & 12 & & 7 & & $38^{26}$ & . & & . & 6 & 3 \\
\hline Bidens cernua & . & & . & & 7550 & . & & . & . & & . & . & 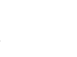 & . & & . & . & . \\
\hline Oxyria digyna & . & & . & & $75^{39}$ & . & & . & 5 & & 5 & 5 & 5 & . & & . & . & 4 \\
\hline Polygonatum verticillatum & . & & . & & $25^{9}$ & . & & . & 15 & & 7 & . & 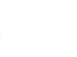 & . & & . & 11 & 8 \\
\hline Sibbaldia cuneata & . & & 28 & & 25 & 83 & 56 & 6 & 36 & 10 & 11 & . & 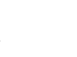 & . & & . & . & . \\
\hline Achillea millefolium & . & & . & & . & $\mathbf{5 0}$ & 56 & . & 5 & & 6 & . & 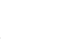 & . & & . & . & . \\
\hline Anaphalis margaritacea & . & & . & & . & 40 & 53 & . & . & & . & . & 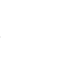 & . & & . & . & . \\
\hline Taraxacum spec. & . & & 11 & & . & 40 & 38 & $\cdot$ & 10 & & 3 & 5 & 5 & . & & . & 17 & 1 \\
\hline Plantago lanceolata & . & & 11 & & . & 43 & 35 & 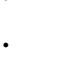 & . & & 3 & & $24 \quad 18$ & . & & . & 11 & 5 \\
\hline Phlomis bracteosa & . & & . & & . & 33 & 25 & . & . & & . & . & 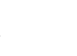 & . & & . & . & . \\
\hline Poa sterilis & . & & . & & . & 23 & 21 & . & . & & 1 & . & 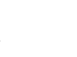 & . & & . & . & . \\
\hline Gypsophila cerastioides & . & & . & & . & 23 & 19 & • & 5 & & 7 & . & 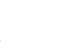 & . & & . & . & . \\
\hline Thymus linearis & . & & . & & . & 37 & 22 & . & 15 & & $15^{1}$ & 5. & & . & & . & . & . \\
\hline \multirow[t]{2}{*}{ Geranium wallichianum } & . & & . & & . & 10 & & 8860 & 10 & & 5 & . & 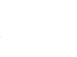 & . & & 9 & 6 & 5 \\
\hline & & & & & & & & & & & & & & & & & Page & 58 \\
\hline
\end{tabular}




\begin{tabular}{|c|c|c|c|c|c|c|c|c|c|c|c|c|c|c|c|c|c|c|}
\hline Communities & 1 & 2 & 3 & & 4 & 5 & & 6 & 7 & & 8 & 9 & & 10 & & 11 & & 2 \\
\hline Fragaria bucharica & . & 28 & . & & 28 & 75 & 14 & $46^{10}$ & 49 & 10 & 5 & & $41 \quad 10$ & 22 & & $\mathbf{5 0}^{1}$ & 105 & \\
\hline Mentha royleana & . & $\cdot$ & . & & . & 50 & 54 & • & . & & 5 & 4 & & 4 & & . & 1 & \\
\hline Micromeria biflora & . & . & . & & . & 44 & 47 & . & . & & 11 & . & & . & & . & 3 & 3 \\
\hline Epilobium parviflorum & . & . & . & . & . & 39 & 43 & . & . & & . & . & & . & & . & . & \\
\hline Carum atrosanguineum & . & . & . & & . & 39 & 41 & . & . & & . & . & & . & & . & . & \\
\hline Arisaema jacquemontii & 10 & . & . & & 3 & 39 & 32 & 13 & 8 & & . & & 19 & 39 & 18 & 18 & 1 & 2 \\
\hline Rumex nepalensis & . & 18 & . & & 20 & 39 & 29 & 16 & 18 & & 5 & 4 & & 16 & & . & & 0 \\
\hline Viola pilosa & . & . & . & & . & 38 & 23 & 3 & 10 & & . & 7 & & . & & 17 & 6 & 5 \\
\hline Rumex acetosa & . & . & . & & . & 35 & 23 & . & 17 & 15 & . & . & & . & & . & . & \\
\hline Salvia moorcroftiana & . & . & . & & . & 25 & 44 & . & . & & 3 & . & & . & & . & . & \\
\hline Microstegium nudum & . & . & . & & . & 25 & 40 & . & . & & . & . & & 9 & & . & . & \\
\hline Convolvulus arvensis & . & . & . & & . & 22 & 25 & . & . & & . & . & & . & & . & . & \\
\hline Geum urbanum & . & . & 35 & 193 & 3 & . & & 10 & 41 & 37 & . & . & & . & & 17 & 1 & 1 \\
\hline Euphorbia wallichii & . & 6 & . & & 30 & . & & $44^{21}$ & 56 & 50 & . & . & & . & & . & . & \\
\hline Podophyllum hexandrum & . & . & . & & . & . & & 21 & 55 & 51 & . & . & & . & & 11 & 3 & 3 \\
\hline Paeonia emodi & . & . & . & & . & . & & 10 & 50 & 53 & . & . & & 4 & & 11 & & 10 \\
\hline Bergenia ciliata & . & 11 & . & & . & . & & 3131 & 5 & & . & . & & 17 & & $28^{1}$ & $18 \quad 1$ & 1 \\
\hline Atropa acuminata & . & . & . & & 7 & . & & . & 25 & 31 & . & . & & . & & . & . & \\
\hline Aquilegia pubiflora & . & . & . & & . & . & & 15 & 24 & 34 & . & . & & . & & . & 3 & 3 \\
\hline Caltha alba & . & . & . & & . & . & & 13 & 22 & 34 & . & 4 & & . & & . & . & \\
\hline Valeriana jatamansi & . & . & . & & 3 & . & & 15 & 28 & 28 & . & & 15 & . & & . & & 14 \\
\hline Rumex dentatus & . & . & . & & . & . & & . & 38 & 36 & . & . & & . & & 11 & 4 & 4 \\
\hline Lamium album & . & . & . & & . & . & & . & 25 & 35 & 14 & . & & . & & . & 3 & 3 \\
\hline Lycopus europaeus & . & . & . & & . & . & & 3 & 22 & 30 & . & . & & . & & . & . & \\
\hline Rumex hastatus & 10 & . & . & & . & . & & . & 2 & & 68 & $54 \quad 7$ & & 43 & 24 . & . & 9 & 9 \\
\hline Lepidium pinnatifidum & . & . & . & & . & . & & . & 1 & & 43 & 29. & & . & & 17 & . & \\
\hline Verbascum thapsus & . & . & . & & . & . & & . & 2 & & 43 & 50. & & 4 & & . & 4 & 4 \\
\hline Tagetes minuta & . & . & . & & . & . & & . & . & & 22 & 35. & & . & & . & . & \\
\hline Pilea umbrosa & . & . & . & & . & . & & . & 8 & & 22 & 20. & & 9 & & 10 & 6 & 6 \\
\hline Bidens tripartita & . & . & . & & . & . & & . & . & & 25 & 19. & & . & & . & . & \\
\hline Onopordum acanthium & . & . & . & & . & . & & . & . & & 24 & 243 & 3330 & 9 & & . & 6 & 6 \\
\hline Artemisia vulgaris & . & 6 & . & & 13 & 19 & & 3 & . & & . & . & & 48 & 23 & 18 & & 44 \\
\hline Hedera nepalensis & . & . & . & & . & 13 & & . & 6 & & . & & 11 & 12 & & 10 & & 222 \\
\hline Cirsium wallichii & . & . & . & & . & 6 & & 3 & 5 & & 8 & . & & 39 & 21 & 281 & 183 & 3 \\
\hline Urtica dioica & . & . & . & & . & . & & 8 & 7 & & . & . & & 26 & 18. & . & 5 & 5 \\
\hline Vitis jacquemontii & . & . & . & & . & . & & . & . & & . & . & & 23 & 28. & . & 1 & 1 \\
\hline Dipsacus inermis & . & . & 11 & & . & . & & 5 & . & & . & . & & 23 & 21. & . & 1 & 1 \\
\hline Eremostachys superba & . & . & . & & . & . & & . & . & & . & . & & 36 & 33. & . & 3 & 3 \\
\hline Senecio chrysanthemoides & . & 6 & . & & . & 6 & & 18 & 44 & 30 & . & . & & 19 & & $78^{3}$ & $30 \quad 1$ & 12 \\
\hline Clinopodium umbrosum & . & . & . & & 10 & 6 & & . & 11 & & 3 & . & & 13 & & $44^{3}$ & $31 \quad 4$ & 4 \\
\hline Arenaria serpyllifolia & . & . & . & & . & . & & . & . & & . & . & & . & & $37^{4}$ & 40 . & . \\
\hline Chrysopogon gryllus & . & . & . & & . & . & & . & . & & . & 7 & & 9 & & $33^{2}$ & $28 \quad 1$ & 13 \\
\hline Galium aparine & . & . & . & & 3 & . & & . & 5 & & 3 & & 11 & 10 & & $33^{2}$ & $21 \quad 1$ & $17^{1}$ \\
\hline Delphinium denudatum & . & . & . & & . & . & & . & 3 & & . & . & & . & & $22^{2}$ & 27 . & . \\
\hline Lepidium apetalum & . & . & . & & . & . & & . & . & & . & . & & . & & $22^{4}$ & 46 . & \\
\hline Eruca sativa & . & . & . & & . & . & & . & . & & . & . & & . & & $21^{3}$ & 33 & \\
\hline Salvia nubicola & . & . & . & & . & . & & . & . & & . & . & & . & & $21^{3}$ & 33. & \\
\hline
\end{tabular}


(2) Laurophyllous Quercus semecarpifolia forest

Elevation range: 2700-3200 m, mainly observed at Sham sar

Bedrock cover: 13(-50)\%

Trees: Picea smithiana, $26 \mathrm{~m}$, Quercus semecarpifolia about $20 \mathrm{~m}$

Shrubs: Rhododendron hypenanthum, $0.5 \mathrm{~m}$

Diagnostic species: Impatiens brachycentra, Primula denticulata, Quercus semecarpifolia

Constant species: Bistorta amplexicaulis, Fragaria bucharica, Picea smithiana

Dominant species: Picea smithiana, Quercus semecarpifolia

Mean number of species ( \pm SD): $7 \pm 2$

Human impact and threat: Quercus semecarpifolia is used for fuel wood by locals; the stem base of

Primula denticulata ("mamera"), an important medicinal plant, is collected

(3) Subalpine Betula-Viburnum treeline scrub

Elevation range: 2900-3300 m, mostly found below Busaro sar

Bedrock cover: not outcropping

Trees: Betula utilis, $10 \mathrm{~m}$

Shrubs: Viburnum grandiflorum, $32 \% ; 2.3 \mathrm{~m}$

Diagnostic species: Aconitum heterophyllum, Arisaema utile, Artemisia dubia, Arum jacquemontii, Bidens cernua, Oxyria digyna, Salvia lanata, Swertia petiolata

Constant species: Aconitum heterophyllum, Arisaema utile, Artemisia dubia, Arum jacquemontii,

Betula utilis, Bidens cernua, Oxyria digyna, Salvia lanata, Swertia petiolata, Viburnum grandiflorum

Dominant species: Viburnum grandiflorum

Mean number of species ( \pm SD): $13 \pm 0.5$

Human impact and threat: Overcollecting of medicinal plants; Aconitum heterophyllum rhizomes are collected to prepare powder used as aphrodisiac and general body tonic.

(4) Alpine turf of Sibbaldia cuneata with Juniperus patches

Elevation range: (2700), 3300-3400 m, mostly found at Kot sar and Busaro sar

Bedrock cover: $12.5(-50) \%$

Trees: Abies pindrow, Pinus wallichiana,13.6(-40) $\mathrm{m}$

Shrubs: Viburnum grandiflorum, Juniperus communis, Juniperus squamata, 0.6(-1.5 m) 
Diagnostic and constant species: Achillea millefolium, Anaphalis margaritacea, Plantago lanceolata, Sibbaldia cuneata, Taraxacum sp.

Dominant species: Sibbaldia cuneata

Mean number of species $( \pm \mathrm{SD}): 11 \pm 3.6$

Human impact and threat: Alpine grasslands are traditionally used in summer for livestock grazing by locals and also by transhumant herders from other areas; local cutting, camp fires and other trekking activities.

(5) Coniferous forest of Abies pindrow and Geranium wallichianum

Elevation range: $2300-2900 \mathrm{~m}$

Bedrock cover: $2.8(-24 \%)$

Trees: Abies pindrow, Quercus semecarpifolia, with Abies 37(-68) \% and 31(-42) $\mathrm{m}$

Shrubs: Indigofera heterantha, Viburnum grandiflorum; $1.5(-2.1) \mathrm{m}$

Diagnostic species: Carum atrosanguineum, Epilobium parviflorum, Geranium wallichianum, Mentha royleana, Micromeria biflora, Microstegium nudum, Salvia moorcroftiana

Constant species: Abies pindrow, Fragaria bucharica, Geranium wallichianum, Mentha royleana, Micromeria biflora

Dominant species: Abies pindrow

Mean number of species ( \pm SD): $10 \pm 3.3$

Human impact and threat: Logging of Abies pindrow; Geranium wallichianum ("Sra Zeela") is locally over-collected; its roots are dug out for medicinal purposes.

(6) Picea smithiana mixed coniferous forest

Elevation range: $2600-2900 \mathrm{~m}$

Bedrock cover: $14.8(-40) \%$

Trees: Abies pindrow, Taxus wallichiana, Picea smithiana; with Picea 26(-68) \% and 25(-34) m; Aesculus indica occurs scattered but is generally found along streams.

Shrubs: Parrotiopsis jacquemontiana, Viburnum grandiflorum, 1.1(-2.6) m

Diagnostic species: Picea smithiana, Taxus wallichiana

Constant species: Abies pindrow, Euphorbia wallichii, Fragaria bucharica, Picea smithiana, Taxus wallichiana, Viburnum grandiflorum

Dominant species: Picea smithiana 
Mean number of species ( \pm SD): $11 \pm 4.3$

Human impact and threat: Picea smithiana yields valuable timber wood used for house building, furniture, wooden bridges and beams; cones are used as ornamental items. Taxus wallichiana wood is used both for fuel and timber. The Picea forest area is declining due to overexploitation; the wood is exported to other parts of the country.

(7) Woodland of Abies pindrow and Viburnum grandiflorum

Elevation range: $2100-2900 \mathrm{~m}$, prevailing vegetation in the area

Bedrock cover: $11.7(-70) \%$

Trees: Abies pindrow, 30(-70) \%; 24(-45) m

Shrubs: Indigofera heterantha, Viburnum grandiflorum, $1.6(-3.2) \mathrm{m}$

Diagnostic species: Abies pindrow, Euphorbia wallichii, Geum urbanum, Lamium album, Paeonia emodi, Podophyllum hexandrum, Rumex dentatus, Viburnum grandiflorum

Constant species: Abies pindrow, Euphorbia wallichii, Fragaria bucharica, Geum urbanum, Paeonia emodi, Podophyllum hexandrum, Senecio chrysanthemoides, Viburnum grandiflorum

Dominant species: Abies pindrow, Viburnum grandiflorum

Mean number of species ( \pm SD): $13 \pm 2.9$

Human impact and threat: Vulnerable; declining in area as a result of overexploitation by extensive logging for the local and national timber market; trees are also cut to establish terrace cultivation. Paeonia emodi and Valeriana jatamansi are among the most sought-after medicinal plants and are collected extensively.

(8) Subtropical groves of Ailanthus altissima

Elevation range: $1600-2000 \mathrm{~m}$

Bedrock cover: $7.5(-70) \%$

Trees: Ailanthus altissima, Morus alba, Olea ferruginea,Pinus roxburghii, $17.5 \%(-44) ; 7.6(22) \mathrm{m}$ Shrubs: Berberis lycium, Desmodium elegans, Indigofera heterantha, Isodon rugosus, Sorbaria tomentosa, 1.1 (2) $\mathrm{m}$

Diagnostic species: Ailanthus altissima, Olea ferruginea, Robinia pseudoacacia, Rubus spec., Rumex hastatus, Tagetes minuta, Verbascum thapsus

Constant species: Ailanthus altissima, Berberis lycium, Isodon rugosus, Lepidium pinnatifidum, Rumex hastatus, Verbascum thapsus 
Dominant species: None

Mean number of species ( \pm SD): $13 \pm 3.3$

Human impact: Rubus fruits are collected;leaves of Robinia fed to animals, underground rhizome of Berberis lycium is harvested to use as blood purifier and against throat infection.

(9) Mixed forest of Quercus floribunda and Pinus wallichiana

Elevation range: (1700) 2200-2400 (2800) m

Bedrock cover: 4.6(-15) \%

Trees: Olea ferruginea, Pinus wallichiana, Quercus floribunda, Quercus oblongata, 45(-80) \%; 15(-32) m

Shrubs: Berberis lycium, Cotoneaster microphyllus, Indigofera heterantha, Parrotiopsis jacquemontiana, Viburnum grandiflorum, Viburnum cotinifolium, Sarcococca saligna, 1.1(-2.1) m Diagnostic species: Quercus floribunda, Pyrus pashia, Sarcococca saligna

Constant species: Berberis lycium, Fragaria bucharica, Indigofera heterantha, Isodon rugosus, Pinus wallichiana, Quercus floribunda

Dominant species: Pinus wallichiana, Quercus floribunda, Sarcococca saligna

Mean number of species ( \pm SD): $12 \pm 4.1$

Human impact and threat: Pinus wallichiana is over-exploited for timber and fuel, its wood is also used for constructing doors and windows. Acorns of Quercus floribunda are collected, roasted and eaten as anti-diuretic. Fruits of Berberis lycium are harvested

(10) Woodland of Abies pindrow and Indigofera heterantha

Elevation range: $2100-2800 \mathrm{~m}$

Bedrock cover: $4.5(-25) \%$

Trees: Abies pindrow, Aesculus indica, Pinus wallichiana, Prunus cornuta, 27(-69)\%; 22(-42) $\mathrm{m}$

Shrubs: Indigofera heterantha, Myrtus communis, Sageretia thea, Sorbaria tomentosa, Spiraea sp., Viburnum grandiflorum 1.7(-2.8) $\mathrm{m}$

Diagnostic species: None

Constant species: Abies pindrow, Artemisia vulgaris, Indigofera heterantha, Rumex hastatus, Viburnum cotinifolium

Dominant species: Abies pindrow

Mean number of species ( \pm SD): $12 \pm 2.8$ 
Human impact and threat: Berberis lycium roots, rhizomes and fruits are collected; potentially vulnerable due to over-collection of Berberis and logging of Abies pindrow

(11) Woodland of Pinus wallichiana with Sorbaria tomentosa shrubbery

Elevation range: $1900-2400 \mathrm{~m}$

Bedrock cover: $3.6(-25) \%$

Trees: Pinus wallichiana, Platanus orientalis, Robinia pseudoacacia; 8.1(-43) \%; 6.2(-28) m

Shrubs: Berberis lycium, Indigofera heterantha, Sorbaria tomentosa, 1.9(-3.1) m

Diagnostic species: Arenaria serpyllifolia, Lepidium apetalum, Rubus ulmifolius, Sorbaria tomentosa

Constant species: Clinopodium umbrosum, Fragaria bucharica, Indigofera heterantha, Senecio chrysanthemoides, Sorbaria tomentosa

Dominant species: Indigofera heterantha, Origanum vulgare

Mean number of species ( \pm SD): $14 \pm 3.7$

Human impact and threat: Being easily accessible and close to settlements, this plant community is highly degraded and partly substituted by terraced croplands of maize, potato, turnip, pea and others, and fruit trees such asapple, walnut, persimmon and peach. Pinus wallichiana woodland is threatened by land use and over-exploitation as the trees are cut both for fuel and timber wood. Origanum vulgare is collected as medicinal plant.

(12) Woodland of Pinus wallichiana with Indigofera heterantha scrub

Elevation range: (1900) 2100-2400 (2900) m

Bedrock cover: $10.5(-65) \%$

Trees: Pinus wallichiana, Prunus cornuta, Rhamnus purpurea, 38(-80) \%; 21.5(-40) m

Shrubs: Spiraea (unident.), Viburnum cotinifolium, Zanthoxylum armatum; $1.6(-2.7) \mathrm{m}$

Dominant and diagnostic species: Pinus wallichiana, Indigofera heterantha

Constant species: Artemisia vulgaris, Fragaria bucharica, Indigofera heterantha, Isodon rugosus Parrotiopsis jacquemontiana, Pinus wallichiana

Mean number of species ( \pm SD): $14 \pm 3.8$

Human impact and threat: The wood of Pinus wallichiana, being durable and moderately hard, is used for construction works. Locals consider it good firewood in spite of its pungent resinous smoke. 
The Pinus woodland is thus moderately susceptible to logging. Fruits of Zanthoxylum armatum are collected and used as condiment.

\section{Gradient analysis and altitudinal zonation}

The first two DCA axes accounted for $34 \%$ of cumulative percentage variance of speciesenvironment relation (Table 2). Elevation was by far the most important variable explaining the distribution of species in the ordination space (Table 3). Based on Pearson's correlation coefficient relevé scores on axis 1 were negatively correlated to elevation (interset correlation value -0.799). From left to right, along the first axis, plant communities are represented from high to low elevation (Figure 3). Also slope (correlation value -0.039) decreases along axis 1. Communities such as Betula utilis scrub, Quercus semecarpifolia and Picea smithiana forests tend to occur at steeper slopes. Latitude is positively correlated with axis 2 (correlation value 0.139) (Table 3).

As revealed by the first ordination axis, aspect plays an important role in woodland communities of Abies pindrow and Pinus wallichiana.

Table 2. Summary of eigenvalues, gradient length, sum of all unconstrained eigenvalues (total inertia) and cumulative percentage variance explained by the first two DCA axes spanning the ordination space of (A) 12 plant communities and (B) four coniferous (Picea, Abies) communities

\begin{tabular}{l|ll}
\hline Summary & A & B \\
\hline Eigenvalue axis 1 & 0.679 & 0.571 \\
Eigenvalue axis 2 & 0.537 & 0.472 \\
Gradient length axis 1 & 8.675 & 5.088 \\
Gradient length axis 2 & 6.094 & 5.065 \\
Total inertia & 29.744 & 18.673 \\
Percentage variance explained & 34.2 & 8.9 \\
\hline
\end{tabular}




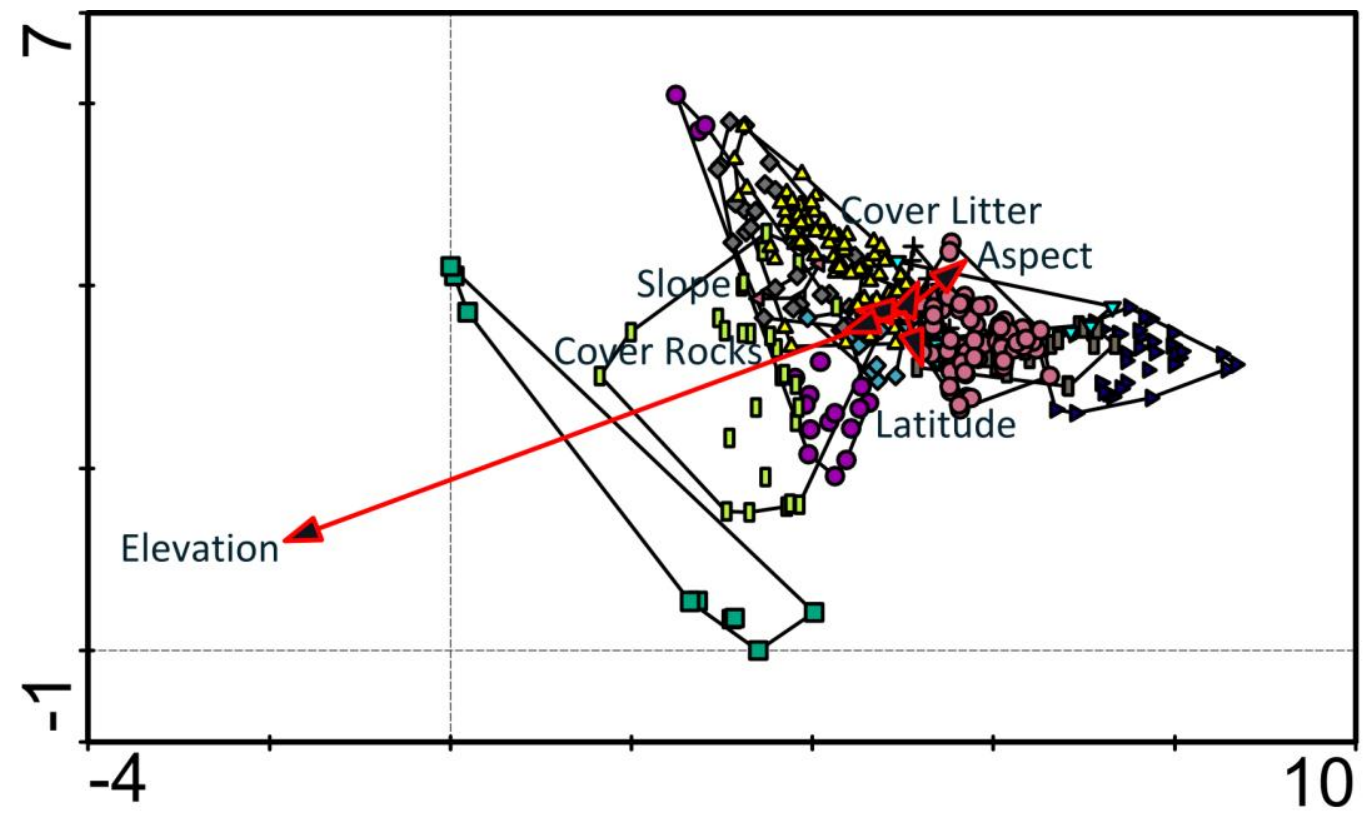

1. Subalpine humid scrub of Betula utilis

3. Subalpine Betula-Viburnum treeline scrub

$\checkmark$ 5. Coniferous forest of Abies pindrow and Geranium wallichianum

$\triangle 7$. Woodland of Abies pindrow and Viburnum grandiflorum

9. Mixed forest of Quercus floribunda and Pinus wallichiana

$\nabla 11$. Woodland of Pinus wallichiana with Sorbaria tomentosa shrubbery

2. Humid laurophyllous forest of Quercus semecarpifolia

4. Alpine turf of Sibbaldia cuneata with Juniperus patches

6. Coniferous forest of Picea smithiana

8. Subtropical semiarid groves of Ailanthus altissima

+10 . Woodland of Abies pindrow and Indigofera heterantha

12. Woodland of Pinus wallichiana with Indigofera heterantha scrub

Figure 3. Indirect ordination plot (DCA) of 12 plant communities with environmental variables plotted a posteriori. For eigenvalues and gradient length along the first two axes refer to Table 2.

Table 3. Correlations between DCA relevé scores and explanatory variables along the first two ordination axes. Values of Pearson's correlation coefficient (r) and significance probabilities (P) are shown.

\begin{tabular}{|c|c|c|c|c|}
\hline Explanatory variables & Axis 1 & & Axis 2 & \\
\hline & $\mathrm{r}$ & $\mathrm{P}$ & $\mathrm{r}$ & $\mathrm{P}$ \\
\hline Elevation & -0.799 & $<0.001$ & -0.022 & - \\
\hline Slope & -0.039 & - & 0.037 & - \\
\hline Aspect & 0.110 & 0.029 & -0.046 & - \\
\hline Litter cover & -0.009 & - & 0.070 & - \\
\hline Rock cover & -0.068 & - & -0.009 & - \\
\hline Latitude & 0.040 & - & 0.139 & 0.005 \\
\hline
\end{tabular}




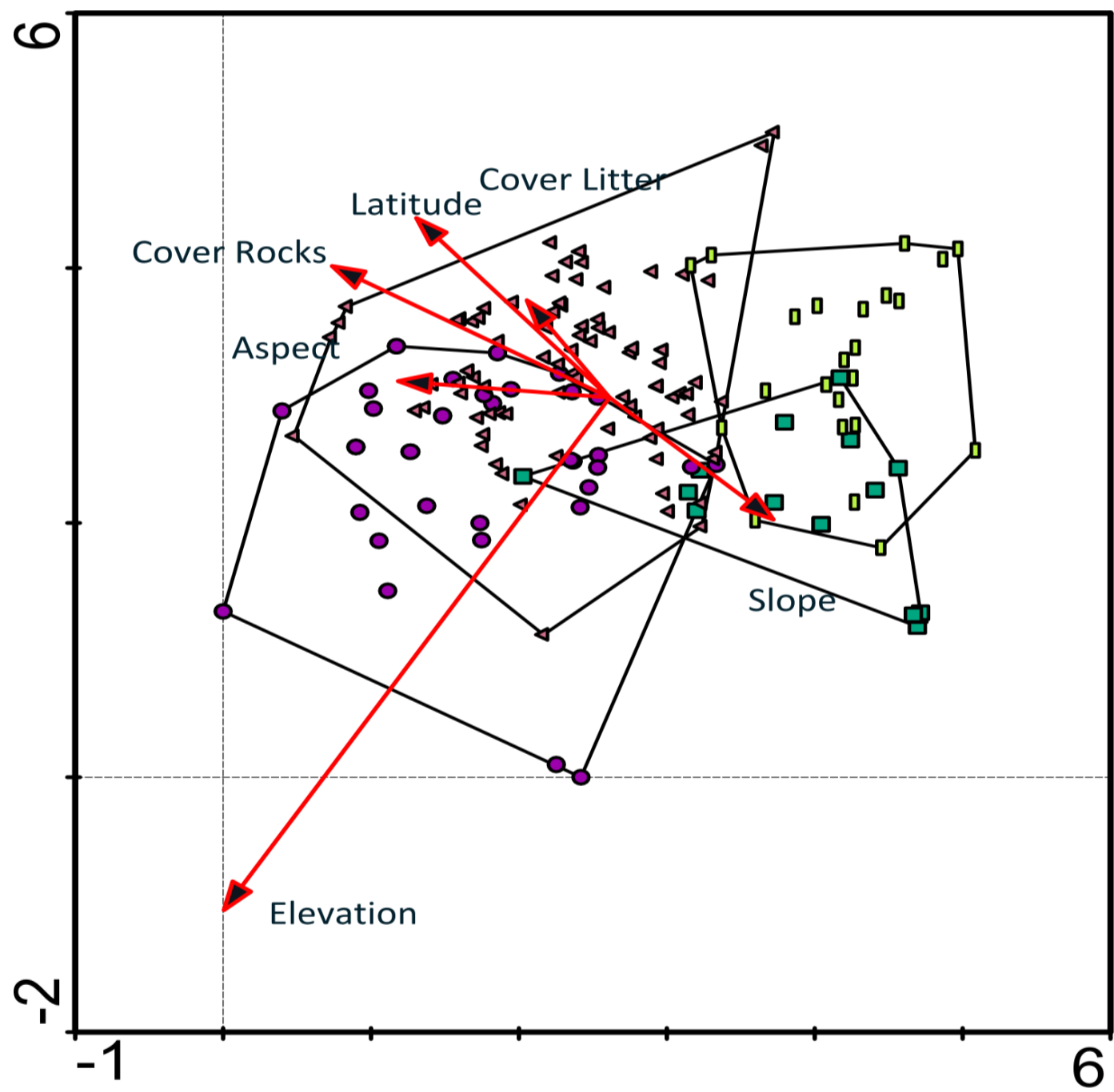

$\square 5$ Coniferous forest of Abies pindrow and Geranium wallichianum

6 Coniferous forest of Picea smithiana

$\checkmark 7$ Woodland of Abies pindrow and Viburnum grandiflorum

$\square 10$ Woodland of Abies pindrow and Indigofera heterantha

Figure 4. Indirect ordination plot (DCA) of 4 coniferous (Abies and Picea) plant communities with environmental variables plotted a posteriori. For eigenvalues and gradient length along the first two axes refer to Table 2 .

The closed canopy supports forest plants such as Podophyllum hexandrum, Paeonia emodi and Euphorbia wallichii in the understory. Compared to other Abies communities the Abies pindrowGeranium wallichianum forest occurs as open vegetation on steep slopes (Figure 4). Litter and rock contributed to explain the ecological conditions of Abies pindrow and Viburnum grandiflorum woodland (Figure 4). Picea smithiana forest occurs at high elevation about $2700 \mathrm{~m}$. There were pure 
stands of Picea smithiana and others mixed with Abies pindrow. Woodland of Abies pindrow and Indigofera heterantha was found at lower elevation.

Correlation analysis of the predictors (elevation, aspect, slope, cover litter, cover rocks and latitude) revealed that elevation is the main determinant of the floristic composition and zonation in the mountains of Miandam (Table 3). Elevation is a proxy of both macro- and meso-climatic differentiation.

Table 4. Elevation belts (named after Schroeder, 1998) in the area of Miandam, North Pakistan, with corresponding vegetation units, their relative cover in the total area and human impact on the vegetation. Vegetation units are numbered as in the text. Overlap in elevation range owing to different aspects.

\begin{tabular}{|c|c|c|c|c|c|c|c|c|}
\hline \multirow{2}{*}{$\begin{array}{l}\text { Vegetation belts with } \\
\text { elevation range }(m)\end{array}$} & \multirow[t]{2}{*}{ Vegetation units } & \multirow[b]{2}{*}{ 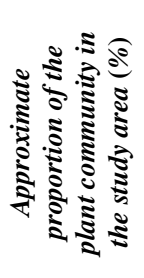 } & \multicolumn{6}{|c|}{ Human impact assessment } \\
\hline & & & 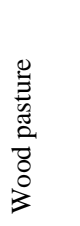 & 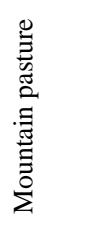 & 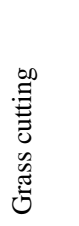 & 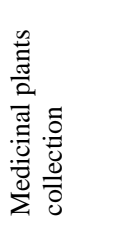 & 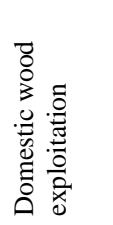 & 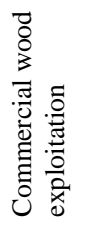 \\
\hline $\begin{array}{l}\text { Alpine } \\
3300-3400\end{array}$ & $\begin{array}{l}\text { 4. Alpine turf of Sibbaldia } \\
\text { cuneata with Juniperus } \\
\text { patches }\end{array}$ & $2-5$ & - & +++ & + & ++ & - & - \\
\hline \multirow[t]{2}{*}{$\begin{array}{l}\text { Subalpine } \\
2900-3300\end{array}$} & $\begin{array}{l}\text { 1. Subalpine scrubof } \\
\text { Betula utilis }\end{array}$ & $1-2$ & ++ & ++ & - & ++ & - & + \\
\hline & $\begin{array}{l}\text { 3. Subalpine Betula- } \\
\text { Viburnum treeline } \\
\text { scrub }\end{array}$ & $2-5$ & + & ++ & + & +++ & - & - \\
\hline \multirow[t]{2}{*}{$\begin{array}{l}\text { Boreal } \\
2600-3200\end{array}$} & $\begin{array}{l}\text { 2. Laurophyllous Quercus } \\
\text { semecarpifolia forest }\end{array}$ & $2-5$ & ++ & - & + & + & ++ & ++ \\
\hline & $\begin{array}{l}\text { 6. Coniferous Picea } \\
\text { smithiana forest }\end{array}$ & $5-10$ & ++ & - & + & ++ & ++ & +++ \\
\hline \multirow[t]{4}{*}{$\begin{array}{l}\text { Upper Nemoral } \\
2100-2900\end{array}$} & $\begin{array}{l}\text { 7. Woodland of Abies } \\
\text { pindrow and Viburnum } \\
\text { grandiflorum }\end{array}$ & $30-35$ & +++ & - & + & +++ & +++ & +++ \\
\hline & $\begin{array}{l}\text { 10. Woodland of Abies } \\
\text { pindrow and Indigofera } \\
\text { heterantha }\end{array}$ & $10-15$ & + & - & + & +++ & ++ & +++ \\
\hline & $\begin{array}{l}\text { 9. Mixed forest of } \\
\text { Quercus floribunda and } \\
\text { Pinus wallichiana }\end{array}$ & $5-10$ & + & - & + & ++ & ++ & ++ \\
\hline & $\begin{array}{l}\text { 5. Coniferous forest of } \\
\text { Abies pindrow and } \\
\text { Geranium } \\
\text { wallichianum }\end{array}$ & $2-5$ & ++ & - & + & ++ & ++ & +++ \\
\hline \multirow[t]{2}{*}{$\begin{array}{l}\text { Lower Nemoral } \\
1900-2400\end{array}$} & $\begin{array}{l}\text { 11. Woodlandof Pinus } \\
\text { wallichiana and } \\
\text { Sorbaria tomentosa } \\
\text { shrubbery }\end{array}$ & $2-5$ & + & - & + & ++ & +++ & + \\
\hline & $\begin{array}{l}\text { 12. Woodlandof Pinus } \\
\text { wallichiana and } \\
\text { Indigofera heterantha } \\
\text { scrub }\end{array}$ & $15-20$ & ++ & - & + & ++ & +++ & ++ \\
\hline $\begin{array}{l}\text { Meridional } \\
1600-1800\end{array}$ & $\begin{array}{l}\text { 8. Sub-tropical grovesof } \\
\text { Ailanthus altissima }\end{array}$ & $1-2$ & +++ & - & ++ & ++ & ++ & + \\
\hline
\end{tabular}

+++Severe, ++Moderate, +Low, -no impact 
The observed plant communities formed six major vegetation belts (Table 4), viz. Meridional (community 8), Lower Nemoral $(11,12)$, Upper Nemoral $(5,7,9,10)$, Boreal $(2,6)$, Subalpine $(1,3)$ and Alpine (4). The timberline at about 3300-3400 m separates alpine pastures largely covered with Sibbaldia cuneata and grasses (Poa spp.) from subalpine krummholz with Betula utilis. In the boreal zone forests of Quercus semecarpifolia with Picea smithiana or Abies pindrow with Picea smithiana occur. Quercus floribunda and Pinus wallichiana were representatives of mixed forest in the upper nemoral zone. In the lower nemoral zone Prunus cornuta, Rhamnus purpurea, Pinus wallichiana and Robinia pseudoacacia were distinct trees. At lower elevations, 1600-1800 m, Ailanthus altissima, Ficus palmata, Morus alba, Melia azedarach, Olea ferruginea and Robinia pseudoacacia were prominent trees of the meridional zone. Non-native trees such as Robinia pseudoacacia and Ailanthus altissima are restricted to the lower zones where human influence is more profound. In a similar elevational sequence, shrub layers may be used to identify the subalpine belt (Salix spec.), and the boreal (Viburnum grandiflorum, Lonicera griffithii, Parrotiopsis jacquemontiana), upper nemoral (Indigofera heterantha, Berberis lycium, Cotoneaster microphyllus, Sarcococca saligna), lower nemoral (Sageretia thea, Indigofera heterantha, Vitex negundo, Sorbaria tomentosa, Rubus ellipticus), and meridional belts (Isodon rugosus).

\section{Discussion}

\section{Comparison with other studies in wider surroundings}

In comparison with other studies in the wider surroundings of Hindukush-Himalaya we found that there are similarities and differences regarding the zonation. In the alpine belt species of mesic grasslands (Sibbaldia cuneata, Danthonia cachemyriana, Phleum alpinum, Agrostis pilosula) (Rana et al. 2011), trampled places (Cenchrus setigerus, Poa annua, Eragrostis poaeoides (Kala and Mathur, 2002; Sher et al. 2013) and moist sites (Rheum australe, Iris hookeriana, Carex nivalis, Carex nubigena, Carex setigera and Bistorta affinis (Khan et al. 2011; Rana et al. 2011) have been recorded. Of these, only Sibbaldia cuneata and Poa spec. were common in the alpine vegetation of Miandam. Betula utilis krummholz seems to be rather unique in our study area as there is no report by other authors except Khan et al. (2011). Species of Rhododendron (anthopogon, campanulatum, lepidotum), Carex (setigera, nivalis), Agrostis pilosula, Salix (lindleyana, denticulata), Persicaria 
polystachya, Lonicera obovata, Berberis (jaeskeana, callibotrys) reported by Rana et al. (2011) have not been recorded from the subalpine belt in the Miandam area.

Table 5.Comparison of the vegetation units described in the present article with those described in other studies of the Hindukush-Himalaya region in the wider surroundings of our study area.

\begin{tabular}{|c|c|c|c|c|c|c|c|c|c|c|c|}
\hline & 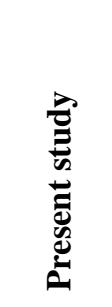 & 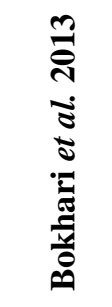 & 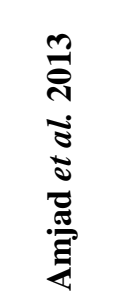 & 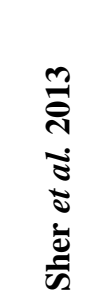 & 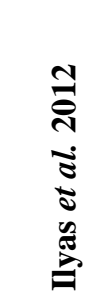 & 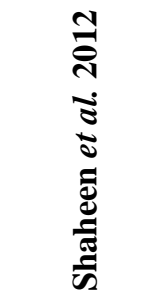 & 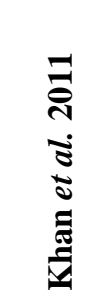 & 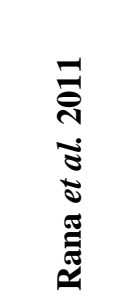 & 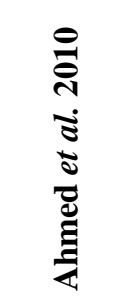 & 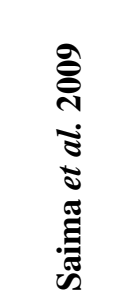 & 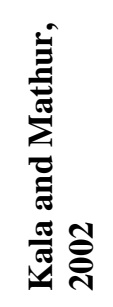 \\
\hline Localities & 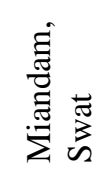 & 章 & 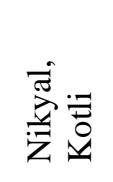 & 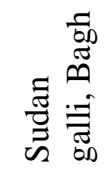 & 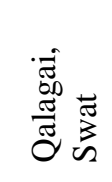 & 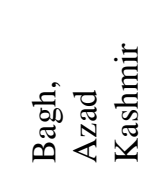 & 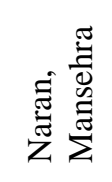 & 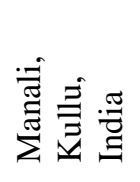 & 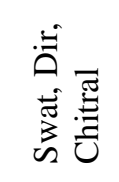 & 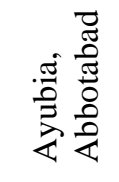 & 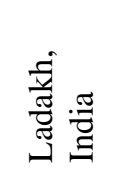 \\
\hline $\begin{array}{l}\text { Elevation } \\
\text { range (m } \\
\text { a.s.l.) }\end{array}$ & $\begin{array}{l}1600- \\
3400\end{array}$ & $\begin{array}{l}799- \\
2900\end{array}$ & $\begin{array}{l}1535- \\
1860\end{array}$ & $\begin{array}{l}2200- \\
2500\end{array}$ & $\begin{array}{l}1450 \\
2892\end{array}$ & $\begin{array}{l}1400- \\
2800\end{array}$ & $\begin{array}{l}2450- \\
4100\end{array}$ & $\begin{array}{l}3540- \\
4485\end{array}$ & $\begin{array}{l}1600- \\
2927\end{array}$ & $\begin{array}{l}\text { Above } \\
2244\end{array}$ & $\begin{array}{l}3000- \\
5500\end{array}$ \\
\hline Alpine & 4 & & & 13 & & & 4,5 & $5-8$ & & & 2 \\
\hline Subalpine & 1,3 & & & & & & 3 & $1-4$ & & & 6 \\
\hline Boreal & 2,6 & $4,5,6$ & & 11 & $6-8$ & $1,3-8,10$ & 2 & & $3-6$ & 1,4 & 5 \\
\hline $\begin{array}{l}\text { Upper } \\
\text { Nemoral }\end{array}$ & $\begin{array}{l}7,10 \\
9,5\end{array}$ & $2,3,7,8$ & 12,13 & $\begin{array}{l}5,7- \\
10,12\end{array}$ & 5 & $2,9,11,12$ & 1 & & $1,2,7,8$ & 3 & $1,3,4$ \\
\hline $\begin{array}{l}\text { Lower } \\
\text { Nemoral }\end{array}$ & 11,12 & 1 & $5-11$ & $1-4,6$ & 3,4 & & & & & 5,2 & \\
\hline Meridional & 8 & 9 & $1-4$ & 1,2 & & & & & & & \\
\hline
\end{tabular}

Present study: 1.Sub alpine scrub of Betula utilis; 2. Laurophyllous forest of Quercus semecarpifolia;

3.Subalpine Betula-Viburnum treeline scrub; 4.Alpine turf of Sibbaldia cuneata with Juniperus patches;

5.Coniferous forest of Abies pindrow and Geranium wallichianum; 6.Coniferous Picea smithiana forest;

7.Woodland of Abies pindrow and Viburnum grandiflorum; 8.Sub-tropical groves of Ailanthus altissima;

9.Mixed forest of Quercus floribunda and Pinus wallichiana; 10.Woodland of Abies pindrow and

Indigofera heterantha; 11.Woodland of Pinus wallichiana and Sorbaria tomentosa shrubbery;

12.Woodland of Pinus wallichiana with Indigofera heterantha scrub.

Bokhari et al. 2013: 1. Pinus roxburghii-Pinus wallichiana; 2.Cedrus deodara-Pinus wallichiana;

3.Abies pindrow-Aesculus indica; 4.Picea smithiana-Abies pindrow; 5.Picea smithiana-Taxus fuana;

6.Pinus wallichiana-Picea smithiana; 7.Abies pindrow-Pinus wallichiana; 8. Pinus wallichiana

monospecific stand; 9. Pinus roxburghii monospecific stand 
Amjad et al. 2013:1. Myrsine-Pinus-Rhus; 2.Olea-Punica-Berberis; 3. Olea-Themeda-Pinus; 4. MyrsineRhus-Pinus; 5. Quercus; 6. Rubus-Quercus-Oxalis; 7. Olea-Themeda-Pinus; 8. Myrsine; 9.QurecusOxalis-Justicia; 10. Quercus-Myrsine-Berberis; 11. Quercus-Rabdosia-Themeda; 12. Pinus-QuercusIndigofera; 13. Pinus-Quercus-Oxalis

Sher et al. 2013:1. Pinus-Berberis-Carex; 2. Pinus-Sarcococca-Hedera; 3. Pinus-Sarcococca-Carex; 4. Pinus-Viburnum-Poa; 5. Pinus-Sarcococca-Carex; 6. Abies-Sarcococca-Fragaria; 7. AbiesSarcococca-Anogromma; 8. Abies-Sarcococca-Urochloa; 9. Abies-Viburnum-Fragaria; 10. AbiesViburnum-Galium; 11.Abies-Viburnum-Viola; 12. Abies-Pinus-Carex; 13. Cenchrus-Poa-Eragrostis Ilyas et al. 2012:1. Populus-Debregeasia-Nasturtium; 2. Olea-Plectranthus-Micromeria; 3. Pinus roxburghii-Plectranthus-Rumex; 4.Quercus-Indigofera-Amaranthus; 5.Pinus wallichiana-IndigoferaGalium; 6.Cedrus-Indigofera-Thymus; 7.Cedrus-Viburnum-Pteridium; 8.Pinus wallichiana-ViburnumLeucas

Shaheen et al. 2012:1. Abies pindrow-Poa alpine; 2. A. pindrow-Viburnum grandiflorum; 3.Pinus wallichiana-Poa pratensis; 4. Pinus wallichiana-Poa alpine; 5. P. wallichiana-Poa pratensis; 6. P. wallichiana-Poa pratensis; 7. A. pindrow-P. wallichiana; 8. A. pindrow-Poa alpina; 9. A. pindrow-V. grandiflorum; 10. A. pindrow-Poa alpina; 11. A. pindrow-V. grandiflorum; 12. A. pindrow-V. grandiflorum

Khan et al. 2011: 1. Pinus wallichiana-Sambucus weightiana; 2. Abies pindrow-Betula utilis; 3. Juniperus excelsa-Artemisia brevifolia; 4. Rheum australe-Sibbaldia cuneata; 5. Aster falconeri-Iris hookeriana

Rana et al. 2011:1.Rhododendron anthopogon, R. campanulatum, Carex setigera, Agrostis pilosula; 2. Salix lindleyana, Carex nivalis, C. setigera, Sibbaldia cuneata; 3. Rhododendron campanulatum, $R$. anthopogon, Persicaria polystachya; 4. Lonicera obovata, Berberis jaeschkeana, Rhododendron lepidotum, Salix denticulata, Carex nivalis; 5. Carex nivalis, Agrostis munroana, Danthonia cachemyriana, Phleum alpinum; 6.Carex nubigena, Agrostis pilosula, Carex setigera, C. nivalis, Bistorta affinis; 7. Poa alpina, Carex setigera, C. nubigena, Trachydium roylei; 8. C. nubigena, Phleum alpinum, Iris hookeriana, Sibbaldia cuneata

Ahmed et al. 2010:1.Deodar-Juglans; 2. Deodar-Quercus; 3. Deodar-Taxus; 4. Deodar-Picea; 5. Deodar-Abies; 6. Deodar-Pinus gerardiana; 7. Deodar-Pinus wallichiana; 8. monospecific Deodar forests

Saima et al. 2009:1.Pinus wallichiana_Fragaria indica; 2. Fragaria indica-Galium aparine; 3. Adiantum venustum - Asplenium trichomanes; 4. Pinus wallichiana association; 5. Plectranthus rugosus-Indigofera gerardiana 
Kala \& Mathur, 2002: 1.Ephedra-Artemisia; 2. Poa annua-Ranunculus hirtellus-Pedicularis oederi; 3.Caragana brevifolia-Cotoneaster; 4. Hippophae rhamnoides-Myricaria germanica; 5. ArtemisiaSalsola collina-Krascheninnikovia ceratoides; 6. Agropyron-Trisetum-Oryzopsis-Carex

In the boreal zone we found Picea smithiana mixed forest, similar only to Bokhari et al. (2013) and Ahmed et al. (2010) but in these studies co-occurring with Cedrus (Table 5). Ilyas et al. (2012) reported two communities dominated by Cedrus deodara from the Qalagai area of Swat. Cedrus deodara is absent as a native tree in our study area while Bokhari et al. (2013) reported a Cedrus deodara-Pinus wallichiana community distributed between 1852 and $2134 \mathrm{~m}$ at Sharda and Keran, Azad Kashmir. Ahmed et al. (2010) reported that Deodar cedars grow in moist to dry temperate mountain woodlands in northern Pakistan from $1650 \mathrm{~m}$ (Kaghan) to $2900 \mathrm{~m}$ (Chitral). Similar to our findings, Shaheen et al. (2012) reported that in Kashmir Abies pindrow and Pinus wallichiana dominate moist temperate forests showing exclusive dominance. In the upper nemoral zone Pinus wallichiana is a common forest species reported in almost all studies. Khan et al. (2011) found Pinus wallichiana, Aesculus indica, Prunus cerasoides, Indigofera heterantha, Viburnum grandiflorum, Viburnum cotinifolium, Paeonia emodi, Bistorta amplexicaulis and Trifolium repens in woodlands of the Naran Valley, Mansehra. Along an $18 \mathrm{~km}$ transect in the Ayubia National Park, district of Abbottabad, Saima et al. (2009) described five plant associations of which the Pinus wallichiana association with Abies pindrow and Taxus wallichiana corresponds to our Pinus-Abies woodlands. In the lower nemoral zone Quercus oblongata has been reported by Ilyas et al. (2012) and Sher et al. (2013) at the same elevation as in our study area. The meridional zone in our study area and that of Amjad et al. (2013) are similar in the common occurrence and dominance of species such as Pinus roxburghii, Olea ferruginea, Indigofera heterantha, Quercus floribunda, Berberis lycium and Themeda anathera. Other prominent species of the meridional zone of Miandam, Ailanthus altissima and Isodon rugosus, are not mentioned by Amjad et al. (2013). In the upper nemoral zone we found a floristic similarity of $23 \%$ of 109 species recorded in our study (with frequency $20 \%$ and more in our case) with the study of Amjad et al. (2013).

\section{Human impact}

Although we did not gather plotwise data on this, we observed extensive clear-cutting of trees and reduced naturalness of the forests. More specifically, we inferred decreasing total area of the 
following communities: Coniferous forest of Abies pindrow and Geranium wallichianum, woodland of Abies pindrow and Viburnum grandiflorum, subtropical groves of Ailanthus altissima and woodland of Pinus wallichiana with Sorbaria tomentosa shrubbery. Interestingly, privately owned

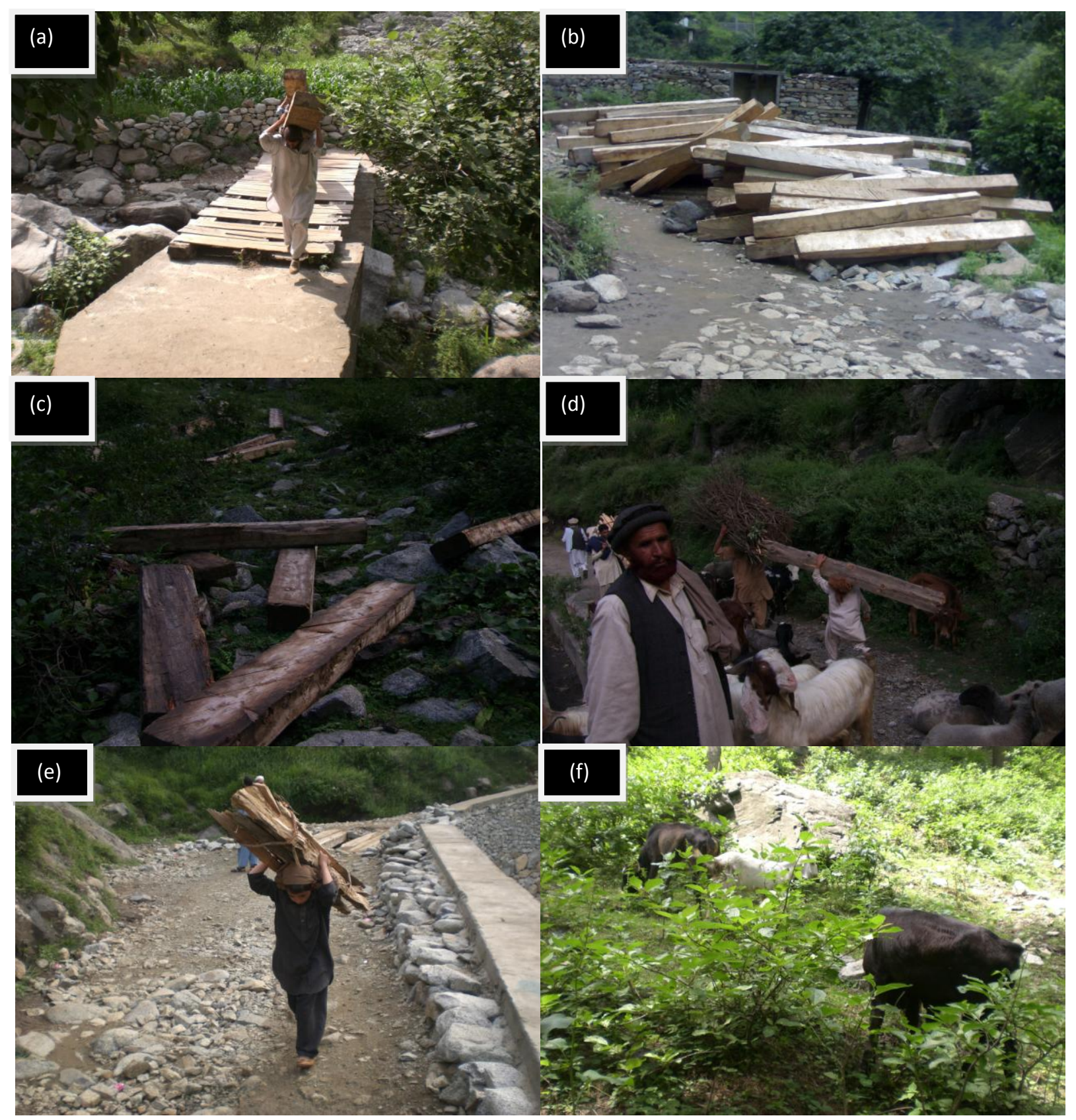

Figure 5. (a) Scants transportation (b) dumped for supply to local market (c) or left in the gorges (d) or later used as fuel wood when spoiled. Also a herder can be seen with goats and sheep (e) Fuel wood collection by children (f) Cattle and goat grazing and browsing. 
forests seem to be better protected and more intact than forests under national protection. Exceptional firs (Abies pindrow) on private land such as at Shahidano sar were found to measure more than $10 \mathrm{~m}$ stem circumference.

Natural succession is commonly inhibited as juvenile trees and saplings are cut, with the intention of enhancing grass growth for cattle. At lower levels, terrace cultivation is increasing. Locals being inquired regarding their preferences about reforestation or agriculture, by majority preferred cultivating various economic crops to sustain family incomes. Ailanthus altissima groves are under the pressure of expanding settlements. The climatically favoured Miandam area attracts people from outside as summer resort, to acquire land and build houses. Illegal clear-cutting, often at night, is chiefly accountable to local businessmen employing laborers. The timber is harvested by local made axe and sometimes diesel chain saws, the logs cut up by two persons with peg-toothed saw, and later transported to the local market (Figure 5). Forest abuse concerns chiefly Abies pindrow and Pinus wallichiana woodlands and specifically the ecosystems of Pinus wallichiana with Indigofera heterantha, Abies pindrow and Indigofera heterantha, and Abies pindrow and Viburnum grandiflorum. Apart from visual evidence, overexploitation of timber was confirmed by celebrities and local informants. In the upper nemoral zone the Abies pindrow-Viburnum grandiflorum woodland ecosystems are further threatened by overcollection of the medicinal plants Paeonia emodi and Podophyllum hexandrum. Medicinal plant trade is in very few hands with access to local and national markets. Forest communities near to settlements are endangered due to logging. Trees are completely girdled to dry and then used as fuel wood and for other domestic purposes. Alpine grasslands in the study area are locally degraded due to overgrazing by livestock of both nomadic and sedentary herding.

Aconitum heterophyllum, Origanum vulgare and Oxyria digyna are important medicinal plants of the subalpine Betula-Viburnum scrub. Primula denticulata is one of the sought after medicinal species in the boreal zone (Akhtar et al. 2013; Singh et al. 2014). Fuel wood harvesting further aggravates the problem of environmental degradation because of selective wood harvesting and also harvesting for sale. Local communities and forest departments, but also every single person is challenged in a participatory manner to work for the protection of the natural environment. Timber mafia should be discouraged and illegal logging cartels must be identified and punished as per forest laws. In spite of possible legislative deficiencies implementation of existing laws will serve to protect the forest from further deterioration. 


\section{Acknowledgements}

This project was funded by higher education commission (HEC) of Pakistan under Faculty development program of Islamia college Peshawar.

\section{Conflict of interest}

The authors do not have any conflict of interest with people or any organization.

\section{Authors agreement}

The authors have read the article and agree with the contents of the article

\section{References}

Ahmed, J. and Mahmood, F.1998. Changing perspectives on forest policy. Policy that works for forests and people series no. 1. IUCN Pakistan and International Institute for Environment and Development,3 Endsleigh Street London WC1H 0DD, UK.

Ahmed,M., Nazim,K., Siddiqui,M.F., Wahab,M., Khan,N., Khan,M.U., Hussain,S.S., 2010. Community Description of Deodar Forests from Himalayan Range of Pakistan. Pakistan Journal of Botany 42, 3091-3102.

Akhtar,N., Rashid,A., Murad,W., Bergmeier,E., 2013. Diversity and use of ethno-medicinal plants in the region of Swat, North Pakistan. J Ethnobiol Ethnomed 9, 25.

Ali,S.I., Qaisar,M., 2001. Flora of Pakistan (Fascicles series). Department of Botany, University of Karachi, Pakistan.

Amjad,M.S., Arshad,M., Qamar,I.A., 2013. Phytosociology Of Pinus-Qurecus forest vegetation of Nikyal Hills, District Kotli, Azad Kashmir, Pakistan. International Journal of Agriculture and Crop Sciences 5, 2952-2960.

Arif,M., Henry,D.J., Moon,C.J., 2011. Host rock characteristics and source of chromium and beryllium for emerald mineralization in the ophiolitic rocks of the Indus Suture Zone in Swat, NW Pakistan. Ore Geology Reviews 39, 1-20.

Beg,A.R., Khan,M.H., 1984. Some more plant communities and the future of dry oak forest zone in Swat valley. Pakistan Journal of Forestry 34, 25-35.

Bokhari,T.Z., Ahmed,M., Siddiqui,M.F., Khan,Z., 2013. Forest Communities Of Azad Kashmir, Pakistan. FUUAST Journal of Biology 3, 137-145.

Breckle, Siegmar W., Dittmann, A., and Rafiqpoor, A. D.2010. Field Guide Afghanistan-Flora and Vegetation. Scientia Bonnensis, Bonn. 
Chawla,A., Rajkumar,S., Singh,K.N., Lal,B., Singh,R.D., Thukral,A.K., 2008. Plant species diversity along an altitudinal gradient of Bhabha Valley in western Himalaya. Journal of Mountain Science 5, 157-177.

Chytrý,M., Tichý,L., Holt,J., Botta-Dukát,Z., 2002. Determination of diagnostic species with statistical fideltity measures. Journal of Vegetation Science 13 (1), 79-90.

Dickoré,W.B., Nüsser,M., 2000. Flora of Nanga Parbat (NW Himalaya, Pakistan): An annotated inventory of vascular plants with remarks on vegetation dynamics. Englera 3-253.

Dierschke, H.1994. Pflanzensoziologie: Grundlagen und methoden. Ulmer Stuttgart.

Eberhardt,E., Dickoré,W.B., Miehe,G., 2007. Vegetation map of the Batura valley (Hunza Karakorum, North Pakistan)(Die Vegetation des Batura-Tals (Hunza-Karakorum, NordPakistan). Erdkunde 93-112.

Hennekens,S.M., Schaminée,J.H.J., 2001. TURBOVEG, a comprehensive data base management system for vegetation data. Journal of Vegetation Science 12 (4), 589-591.

Hussain,F., Ilyas,M., Gil,K., 1995. Vegetation studies of Girbanr Hills District Swat, Pakistan. The Korean journal of Ecology 18, 207-218.

Hussain,F., Saljoqi,A.R., Shah,A., Ilahi,I., 1992. Phytosociology of the vanishing sub-tropical vegetation of Swat with special reference to Docut hills II: Spring aspect [Pakistan]. Sarhad Journal of Agriculture 8, 185-191.

Ilyas,M., Shinwari,Z.K., Qureshi,R., 2012. Vegetation composition and threats to the montane temperate forest ecosystem of Qalagai hills, Swat, Khyber Pakhtunkhwa, Pakistan. Pakistan Journal of Botany 44, 113-122.

Kala,C.P., Mathur,V.B., 2002. Patterns of plant species distribution in the Trans-Himalayan region of Ladakh, India. Journal of Vegetation Science 13, 751-754.

Khan,N., 2012. A community analysis of Quercus baloot Griff, forest. District Dir Upper, Pakistan. African Journal of Plant Sciences 6, 21-31.

Khan,S.M., Page,S., Ahmad,H., Harper,D., 2013. Identifying plant species and communities across environmental gradients in the Western Himalayas: Method development and conservation use. Ecological Informatics 14, 99-103.

Khan,S.M., Harper,D.M., Page,S., Ahmad,H., 2011. Species and community diversity of vascular Flora along environmental gradient in Naran Valley: A multivariate approach through indicator species analysis. Pakistan Journal of Botany 43, 2337-2346.

Malik,R.N., Husain,S.Z., 2006. Classification and ordination of vegetation communities of the Lohibehr reserve forest and its surrounding areas, Rawalpindi, Pakistan. Pakistan Journal of Botany 38, 543-558. 
New,M., Lister,D., Hulme,M., Makin,I., 2002. A high-resolution data set of surface climate over global land areas. Climate research 21, 1-25.

Nüsser,M., Dickoré,W.B., 2002. A tangle in the triangle: vegetation map of the eastern Hindukush (Chitral, northern Pakistan). Erdkunde 37-59.

Peer,T., Millinger,A., Gruber,J.P., Hussain,F., 2007. Vegetation and altitudinal zonation in relation to the impact of grazing on the steppe lands of the Hindu Kush Range (N-Pakistan). Phytocoenologia 31 (4), 477-498.

Porter,S.C., 1970. Quaternary glacial record in Swat Kohistan, west Pakistan. Geological Society of America Bulletin 81, 1421-1446.

Rana,M.S., Samant,S.S., Rawat,Y.S., 2011. Plant communities and factors responsible for vegetation pattern in an alpine area of the northwestern Himalaya. Journal of Mountain Science 8, 817-826.

Rashid,A., Swati,M.F., Sher,H., Al-Yemeni,M.N., 2011. Phytoecological evaluation with detail floristic appraisal of the vegetation around Malam Jabba, Swat, Pakistan. Asian Pacific journal of tropical biomedicine 1, 461-467.

Roleček,J., Tichý,L., Zeleny,D., Chytry,M., 2009. Modified TWINSPAN classification in which the hierarchy respects cluster heterogeneity. Journal of Vegetation Science 20, 596-602.

Saeeda,Y. Deforestation and its impacts on livelihood opportunities in Miandam Valley Swat, Ethnobotany Project, WWF-Pakistan. 2005.

Ref Type: Report

Saima,S., Dasti,A.A., Hussain,F., Wazir,S.M., Malik,S.A., 2009. Floristic compositions along an 18$\mathrm{km}$ long transect in Ayubia national park district Abbottabad, Pakistan. Pakistan Journal of Botany 41, 2115-2127.

Schroeder, F. G.1998. Lehrbuch der Pflanzengeographie. Quelle \& Meyer verlag Wiesbaden.

Shaheen,H., Khan,S.M., Harper,D.M., Ullah,Z., Allem Qureshi,R., 2011. Species diversity, community structure, and distribution patterns in western Himalayan alpine pastures of Kashmir, Pakistan. Mountain Research and Development 31, 153-159.

Shaheen,H., Ullah,Z., Khan,S.M., Harper,D.M., 2012. Species composition and community structure of western Himalayan moist temperate forests in Kashmir. Forest Ecology and Management 278, 138-145.

Sher, H., Al yemeni,M.N., 2011. Economically and ecologically important plant communities in high altitude coniferous forest of Malam Jabba, Swat, Pakistan. Saudi Journal of Biological Sciences 18, 53-61. 
Sher, Z., Hussain, F., Badshah, L., Khan, A.U., Ahmad, F., Sharif, F., Khan, M.U., Ahmed, M., Shaukat, S.S., Nazim, K., 2013. Phytosociology of summer vegetation of Sudan Galli hills, District Bagh, Azad Kashmir, Pakistan. Pakistan Journal of Botany 45, 1-9.

Singh, S., Farswan, M., Ali, S., Afzal, ., Al-Abbasi, F.A., Kazmi, I., Anwar, F., 2014. Antidiabetic potential of triterpenoid saponin isolated from Primula denticulate. Pharm. Biol 52, 750-755.

Takhtajan, A., Crovello, T. J., and Cronquist, A.1986. Floristic regions of the world. University of California press Berkeley.

Ter Braak, C.J.F., Šmilauer,P., 2002. CANOCO reference manual and user's guide to Canoco for Windows: software for canonical community ordination (version 4.5). Microcomputer Power, Ithaca, New York, USA.

Tichý, L., 2002. JUICE, software for vegetaion classification. Journal of Vegetation Science 13 (3), 451-453.

Urrahman, M.2012. Wild plants of Swat,Pakistan. Department of Botany Government Jahanzeb Post graduate College,Saidu Sharif, Swat, Pakistan.

Zahid,M., Rasul,G., 2011. Thermal classification of Pakistan. Atmospheric and Climate Sciences 1, 206-213. 


\title{
CHAPTER 4
}

\section{SPECIES RICHNESS, ALPHA AND BETA DIVERSITY OF TREES, SHRUBS AND HERBACEOUS PLANTS IN THE WOODLANDS OF SWAT, PAKISTAN}

\author{
NAVEED AKHTAR ${ }^{1,2}$ \& ERWIN BERGMEIER ${ }^{2}$ \\ ${ }^{\mathbf{1}}$ Department of Botany, Islamia College, Peshawar, 25000, Pakistan \\ ${ }^{2}$ Department of Vegetation Analysis and Phytodiversity, Albrecht von Haller Institute of Plant \\ Sciences, Georg August University, 37073 Göttingen, Germany \\ Corresponding author: \\ Naveed Akhtar \\ eMail: naveedakhter75@yahoo.com \\ Phone: +92-300-5997454 \\ Erwin Bergmeier \\ eMail: erwin.bergmeier@bio.uni-goettingen.de \\ Phone: +49-551-39-5700
}

Accepted: Pakistan Journal of Botany 


\begin{abstract}
We explored the variation in species richness and diversity of trees, shrubs and herbs in the mountains of Miandam, Swat, North Pakistan, along an elevation gradient between $1600 \mathrm{~m}$ and 3400 m. Field data were collected in 18 altitudinal intervals of $100 \mathrm{~m}$ each. Polynomial regression was used to find relations of the different growth forms with elevation. The Shannon index was used for calculating $\alpha$-diversity and the Simpson index for $\beta$-diversity. Species richness and $\alpha$-diversity of herbs were unrelated to elevation. Herbaceous species turnover was high, ranging between 0.46 and 0.89, with its maximum between 2700 and $3000 \mathrm{~m}$. Hump-shaped relationship was observed for shrubs with maximum richness between 2000 and 2200 m; and $\alpha$-diversity decreased monotonically. Turnover of shrub species was highest between 2000 and $2500 \mathrm{~m}$. Tree species richness was highest at low elevations, and $\alpha$-diversity was relatively low along the entire gradient. Tree species turnover was also high in the lower zone and again at 2600-2800 m. Species richness of all vascular plants was highest at 2200-2500 m, and $\alpha$-diversity was highest in the lower part of the gradient. Beta diversity of all growth forms was quite high ranging between 0.53 and 0.87 along the entire gradient reflecting high species and structural turnover.
\end{abstract}

Key words: elevation gradient, Himalayas, mountain woodlands, plant diversity, Shannon index, Simpson beta diversity, vegetation zonation 


\section{Introduction}

Variation in species richness along elevation has been observed for over a century (Wallace, 1878; Pianka, 1966; Lomolino, 2001; Sanders and Rahbek, 2012). Rahbek (1995; 2005), in his reviews of scale and species richness, found that most studies showed mid-elevation peaks along elevation gradients. He identified three main patterns of richness: (1) monotonic decrease with increasing altitude, (2) a plateau at low altitudes and (3) hump-shaped distribution with high richness at intermediate altitudes. Similarly, according to (McCain, 2009) elevational patterns in species richness fall into four common patterns (1) decreasing, (2) low plateau, (3) low plateau with midelevational peak and (4) mid-elevation peak. Evidently, the pattern of species richness along elevation differs in different regions, with monotonic decrease (Austrheim, 2002; Ohlemüller and Wilson, 2000; Panayiotis et al., 2013), hump-shaped relationship (Lomolino, 2001; Acharya et al., 2011; Bhattarai and Vetaas, 2006), or both patterns in the same region (Grytnes, 2003). In some studies even bimodality has been reported (Xu et al., 2011). Wang et al. (2007) found that richness and density (richness/log-transformed area) of seed plants at species, genus, and family levels all showed hump-shaped patterns along the altitudinal gradient. Bhattarai and Vetaas (2003) found that shrubs, trees and total species (sum of all life forms) showed unimodal responses, ferns decreased monotonically and woody climbers increased monotonically. Richness of all woody groups increased monotonically with increasing mean annual rainfall and humidity. Some researchers, like Grytnes and Beaman (2006) and Kessler (2000),established that elevational patterns in species richness depend on the group studied and on the region, e.g. ferns in Mexico (Tyron, 1989), Bolivia (Kessler, 2000) and Malaysia (Parris et al., 1992). Ren et al. (2006) found that total vascular plant species richness did not exhibit a linear altitudinal pattern, albeit species groups with different ecological features showed strong elevational patterns. Individual growth forms vary in response to elevation, e.g. herbs in New Zealand (Ohlemüller and Wilson, 2000), trees and shrubs in South Africa (O' Brien, 1993) and climbers in Mexico (Vazquez and Givnish, 1998).

The South Asian mountain ranges (Himalayas, Hindukush, Karakorum), with the highest peaks in the world, comprise a very wide range of ecoclimate zones (Dobremez and Jest, 1976). These mountains are therefore an excellent system for evaluating ecological and biogeographical patterns and theories of species richness (Körner, 2000). Some authors (Khan et al., 2010; Khan et al., 2011; Saqib et al., 
2011; Shaheen and Shinwari, 2012) provided studies related to species diversity, community structure and distribution patterns of plant species in the Hindukush-Himalaya region in Northern Pakistan. Our study is the first for any area in northern Pakistan with statistical determination of species richness and diversity of different growth forms along elevation. We focused on two questions: (I) Do species richness and diversity vary along elevation and among different growth forms? (II) Is variation along the elevational gradient monotonic, unimodal or otherwise?

\section{Materials and Methods}

\section{Study area}

The study was carried out in the area of Miandam, district of Swat, North Pakistan (35 $1-5^{\prime} \mathrm{N}$, 72 ${ }^{\circ}$ 30-37' E;Figure 1).The mountainous area, about $50 \mathrm{~km}$ NNE of the district capital,Saidu Sharif, is part of an offshoot of the Himalaya range ascending to $3500 \mathrm{~m}$ According to Zahid and Rasul (2011) and based on Thornthwaite's index of thermal efficiency (ratio of temperature to evapotranspiration), the research area falls in the "mild microthermal" zone. March, July and August are months with heavy rainfall (New et al., 2002). December and January are the coldest months with temperatures down to a mean minimum of $-10^{\circ} \mathrm{C}$ in the higher reaches of the nemoral forest areas (Saeeda, 2005).On the valley sides at $1600-1800 \mathrm{~m}$ the area is dominated by sparse shrubby vegetation of Berberis lycium, Isodon rugosus and Sorbaria tomentosa. In the boreal belt as defined by Schroeder (1998) Picea smithiana is the dominant tree and Taxus wallichiana associated. The upper and lower nemoral belts are characterized by Abies pindrow and Pinus wallichiana forests, respectively. Indigofera heterantha and Viburnum grandiflorum are common understory shrubs of Pinus and Abies woodlands. In the subalpine belt Betula utilis and Salix spp. dominate; in the alpine zone Sibbaldia cuneata is common.

\section{Field sampling}

Field work was carried out in the summer months of 2010 through 2012. The elevation gradient between 1600 and $3400 \mathrm{~m}$ was divided into $100 \mathrm{~m}$ intervals. Four hundred vegetation quadrats of 10 $\times 10 \mathrm{~m}$ were placed along the gradient in stratified wooded and sparsely wooded areas covering all intervals and the entire vegetation zonation. Elevation was measured using GPS device. Plant samples were collected of almost all vascular plant species and identified using (Ali and Qaisar, 2001; Breckle et al., 2010; Urrahman, 2012). Herbarium collections of the Botanische Staatssammlung (M), München, Germany, were compared for confirmation. 


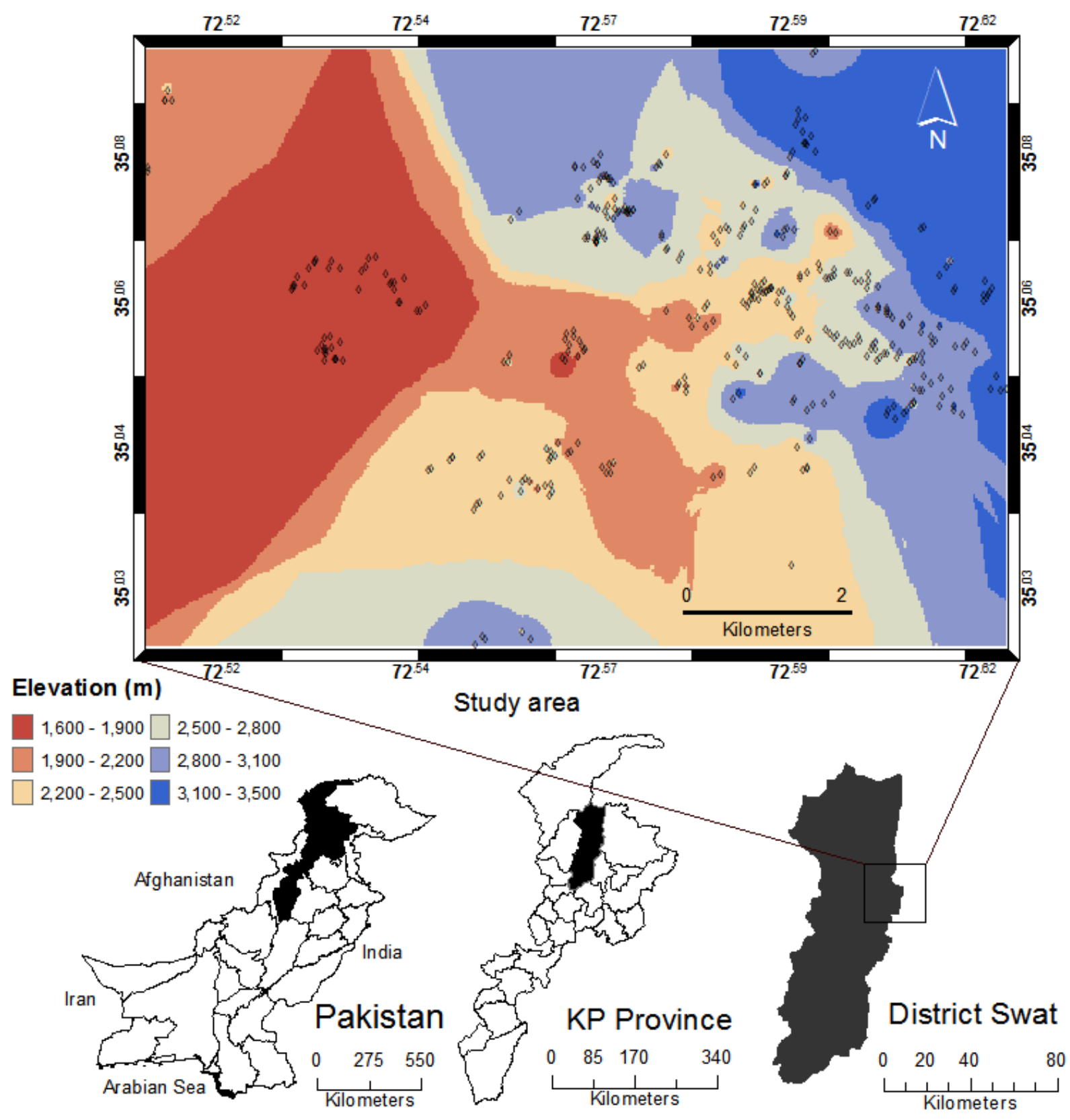

Figure 1.Georeferenced map showing the sampling sites (rhombi) and topography of the study area in the district of Swat, Khyber Pakhtunkhwa (KP) Province,Northern Pakistan. 


\section{Data analysis}

In our analyses, we distinguished the growth forms herb, shrub and tree. Three indices were chosen to estimate richness and diversity: (1) species richness, i.e., the total number of plant species recorded in each 100 m elevation interval (Bhattarai et al., 2004; Grau et al., 2007; Vetaas and Grytnes, 2002). (2) Shannon ("Shannon-Wiener") index of diversity ( $\left.H^{\prime}=-\sum_{i=1}^{s} p i \ln p i\right)$ where $S$ is the total number of species at the elevation and $p i$ is the proportion of all the individuals in the quadrat. Instead of counting the individual plants species, cover relative to the total cover was calculated (Fosaa, 2004). Values of Shannon index were exponentiated as suggested by (Jost, 2006). (3) Simpson beta diversity index $\left(\beta_{\operatorname{simp}}=1-\frac{a}{\min (b, c)+a}\right)($ Koleff et al., 2003), where $a$ is the number of shared species between two quadrats while $b$ and $c$ are numbers of species unique to either quadrat. In our case $\beta_{\text {simp }}$ is pairwise comparison among quadrats based on presence and absence of species. Here min $(b, c)$ is the minimum number of unique species of either $b$ or $c$. As the sample plots were unequally distributed in the study area we calculated the three indices based on seven quadrats per100 $\mathrm{m}$ interval (seven quadrats being the minimum number sampled in any interval). We randomized our samples five times in each elevation interval where more than seven quadrats were sampled. After randomization mean values were taken for further analyses. To find patterns of diversity, species richness, Shannon and Simpson beta diversity indices were regressed against elevation. Diversity indices were computed in JUICE 7.0 (Tichý, 2002) and polynomial regression in R 2.15.3 (R Core Team, 2014). Akaike's information criterion (AIC) was used for model selection, with the minimum AIC as the best-fit estimator.

\section{Results}

\section{Species richness in relation to elevation}

We recorded a total of 411 species in the samples. Most of the species were herbaceous (77\%), trees account for $8 \%$, shrubs constitute $12 \%$, and woody climbers $3 \%$ of the total number of species. 
The variation in species richness of the three growth forms and total species richness is shown in Figure 2. The polynomial regression models did not predict a significant relationship between herb richness and elevation. A hump-shaped relationship was found between shrub richness and elevation with maximum richness between 2000 and $2200 \mathrm{~m}$. Minimum shrub richness was observed between 3000 and $3200 \mathrm{~m}$. Tree species richness initially decreased until $2200 \mathrm{~m}$, then increased and from
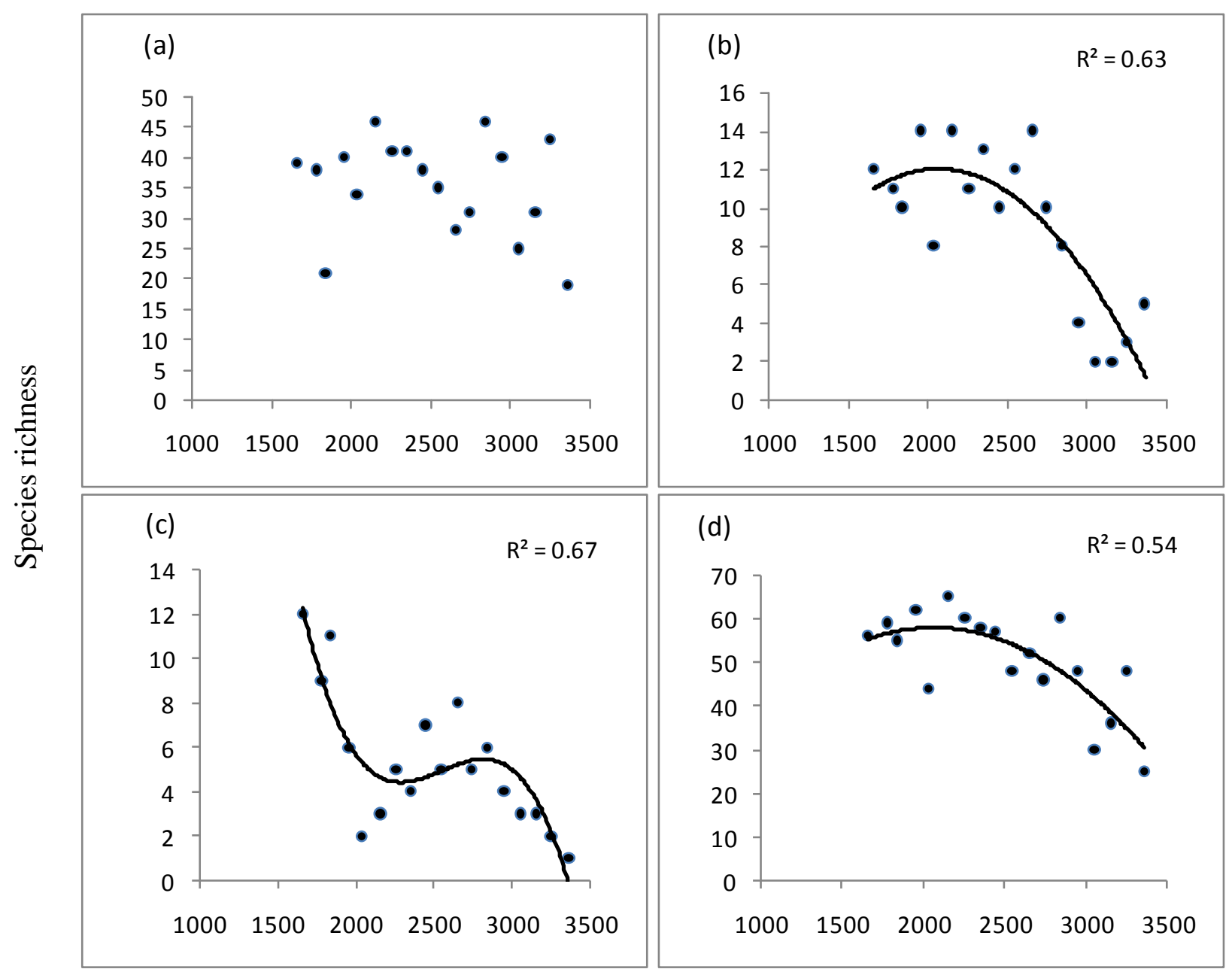

Elevation (m)

Figure 2. Relationship between species richness and elevation for (a) herbs, (b) shrubs, (c) trees, and (d) total vascular plants. $\mathrm{R}^{2}$ value is adjusted. While herb richness along elevation was statistically insignificant, quadratic, cubic and quadratic regressions based on significant $\mathrm{F}$ and AIC values were significant for richness of shrubs, trees and total vascular plants, respectively.

$2800 \mathrm{~m}$ onward decreased again. Total species richness followed a unimodal pattern along the elevation gradient; quadratic regression showed a significant fit to the trend of variation. 


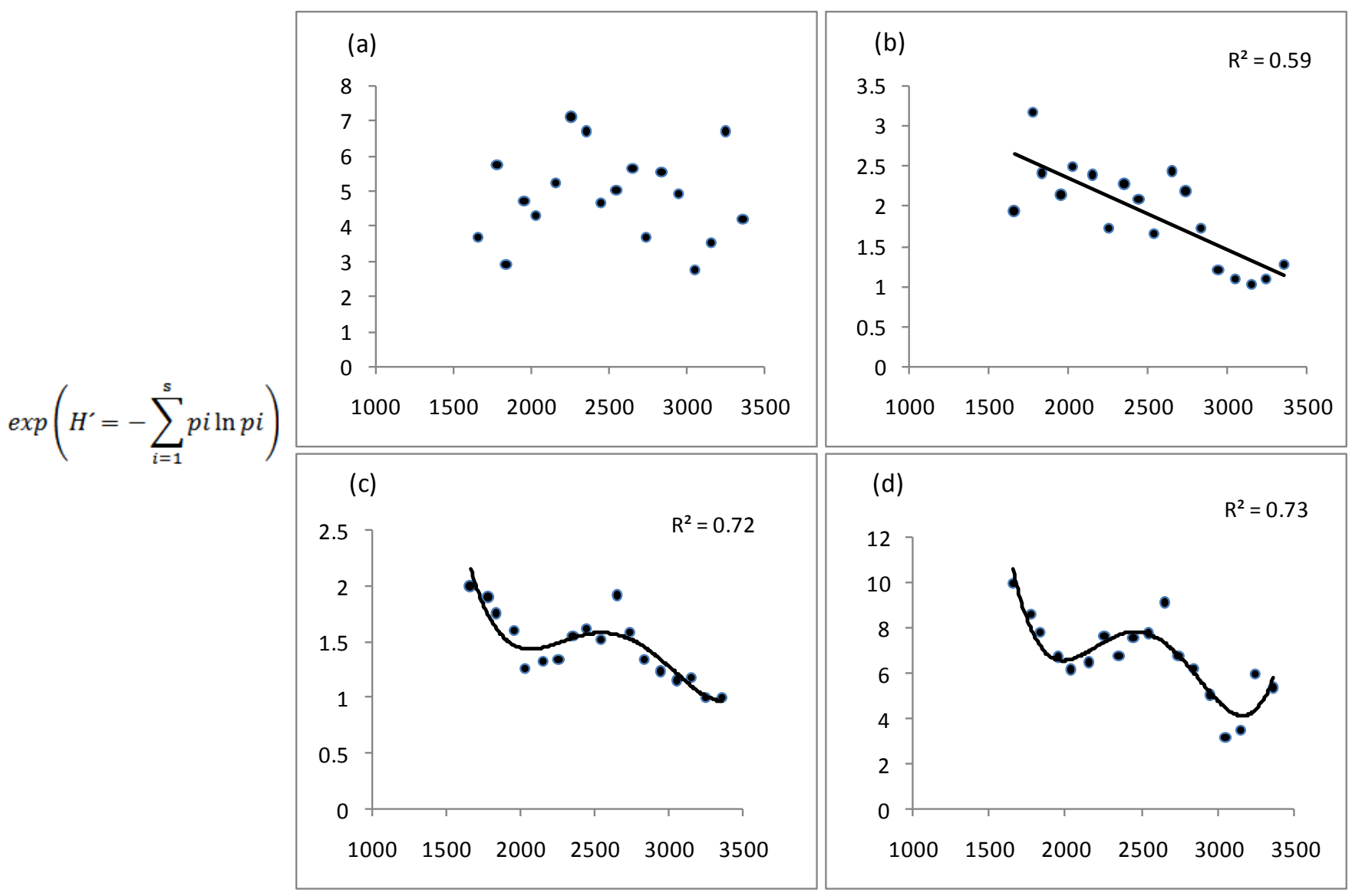

Elevation (m)

Figure 3. Relationship between exponentiated Shannon diversity with elevation for (a) herbs, (b) shrubs, (c) trees, and (d) total vascular plants. $R^{2}$ value is adjusted. Based on significant $F$ and AIC values linear, cubic and quartic regressions were significant for alpha diversity of shrubs, trees and all vascular plants, respectively. For herbs Shannon diversity was insignificant.

\section{Alpha diversity in relation to elevation}

Shannon diversity for herbs was insignificant to elevation. All polynomial models up to 4th order failed to predict any significant relationship of herb diversity with elevation (Figure 3). For shrubs the Shannon diversity decreased monotonically. The lowest Shannon diversity of 1.02 for shrubs was observed at about $3150 \mathrm{~m}$ and the highest Shannon diversity of 3.15 was observed at low elevations of about $1800 \mathrm{~m}$. Shannon diversity for trees was also low along the gradient studied. Alpha diversity for vascular plants as a whole was highest at low $(1600 \mathrm{~m})$ and medium $(2700 \mathrm{~m})$ altitudes and lowest in the uppermost forest zone $(3100 \mathrm{~m})$. 
high at low elevations, then decreased as the elevation increased, remaining fairly constant along the forest zones until a further decrease at and above $3000 \mathrm{~m}$. Species turnover for vascular plants in toto ranged between 0.53 and 0.87 showing overall high $\beta$-diversity.

\section{Discussion}

\section{Variation in species richness}

Similar to(Bhattarai and Vetaas, 2003) the relationship between herb richness and elevation was statistically insignificant but for shrubs, trees, and vascular plants as a whole richness was significant. In a study from New Zealand, Ohlemüller and Wilson (2000) found no relationship between herbaceous species richness (groundflora) and elevation. In terms of species richness herb diversity is high if compared to the findings of (Khan et al., 2011). In lower areas, annual disturbance indicators such as Dicliptera bupleuroides, Sonchus spp., Cannabis sativa, Lepidium pinnatifidum, Chenopodium album, Solanum pseudocapsicum and many others are common and outnumber genuine woodland plants. At subalpine reaches light-demanding perennial species such as Potentilla atrosanguinea, Pedicularis pyramidata, Sibbaldia cuneata, Impatiens thomsonii, Pleurospermum stellatum and Clinopodium umbrosum are common. Effects of different life forms may blur a possible richness response of woodland herbs among which hemicryptophytes and geophytes are prevailing. Mahdavi et al. (2013) found that annuals decreased, and hemicryptophytes increased along a $3000 \mathrm{~m}$ altitudinal gradient in Iran.

Shrubs showed a unimodal pattern in the studied area with maximum richness in the middle of the elevation gradient. Transhumance affecting shrub growths in woodlands particularly at lower and at subalpine levels close to the winter and summer pastures, respectively, may explain such a pattern. High tree species richness in the lower zone is probably due to anthropogenic habitat disturbance and deforestation supporting alien tree species such as Ailanthus altissima and Robinia pseudoacacia, but also opportunistic native trees such as Ficus palmata. Infrequent deciduous tree species like Rhamnus purpurea and Prunus cornuta which are largely confined to the nemoral zone add to the relatively high mid-elevation tree species richness.

Decreasing total species richness above about $2700 \mathrm{~m}$ may be due to increasingly harsh natural conditions in the upper boreal and subalpine belts (Colwell and Lees, 2000; Grytnes and Vetaas, 2002).A mid-elevation peak of species richness as observed in Swat is a common pattern on many mountains (Grytnes, 2003). 


\section{Variation in $\alpha$-diversity}

In our index for $\alpha$-diversity we used relative species cover. As with richness, and probably for the same reasons (see above) we could not identify a relationship between herb diversity and elevation. Alpha diversity of shrubs, being low throughout, decreased along the gradient. Some shrub species,e.g. Isodon rugosus, Desmodium elegans, Sorbaria tomentosa, are more or less equally distributed but decrease at upper levels. Patterns of tree species richness and $\alpha$-diversity are quite similar and indicate that abundance of different tree species seems to affect $\alpha$-diversity in much of the elevation gradient. Quartic regression model shows a significant trend of variation of $\alpha$-diversity of the vascular plants against elevation. The pattern is similar to $\alpha$-diversity of trees and, interestingly, in consonance with a $1300 \mathrm{~m}$ elevation gradient in the Sierra Nevada, Mexico (Sánchez-González and López-Mata, 2005).

\section{Variation in $\beta$-diversity}

Beta diversity is a key concept for understanding ecosystem patterns, for biodiversity conservation and ecosystem management (Legendre et al., 2005). In the study area, species turnover of herbs varied along the gradient between 0.46 and 0.89 . Beta diversity of the herbs and of the vascular plants as a whole were similar. Low-elevation woodland disturbance indicators including neophytes such as Cannabis sativa, Datura innoxia and Galinsoga parviflora add to the high level of beta diversity at lower altitudes. From $2900 \mathrm{~m}$ onward, there is low turnover of herbs, probably due to the increasingly controlling effect of climate over other environmental factors. Increase in beta diversity of shrubs at 1800-2400 $\mathrm{m}$ and 3100-3350 m reflects the effect of certain range-restricted native species. Between 1800 and $2400 \mathrm{~m}$ Indigofera heterantha, Viburnum grandiflorum and Sarcococca saligna appear. The first two are among the most widely distributed shrub species of the area. At and beyond the subalpine belt characteristic species such as Salix spp. and Cassiope fastigiata cause high beta diversity at the high end of the gradient. Species turnover of trees is high only on the valley sides and rather low at higher reaches. This is due to the dominance at nemoral through boreal levels of the competitive forest trees Pinus wallichiana, Abies pindrow and Picea smithiana.

\section{Conclusion}

We confirmed our initial research questions. Shrubs, trees and non-woody plants varied in richness and diversity along the investigated elevation gradient of $1800 \mathrm{~m}$ from the valley bottom to the summits. Much of the richness and diversity variation along elevation of shrubs and trees could be explained by different response models including monotonic, hump-shaped, and more complicated 
relationships. The growth form category 'herb' seems to be too unspecific to reveal a significant elevational pattern. Life form categories responding to the climatic change along the altitudinal gradient may be expected to perform better. There is considerable redundancy in our study in what is revealed by the concepts of species richness and $\alpha$-diversity, while $\beta$-diversity provided additional clues for interpretation. The detailed interpretation of the findings proves difficult and is likely to be multi-faceted. Apart from the obvious, increasing precipitation and decreasing temperature with increasing altitude, disturbance effects in the woodlands of Swat seem to be accountable for some of the altitudinal diversity and richness phenomena. The effect of ruderal annuals and arboreal and herbaceous neophytes, for instance, is most pronounced on the low valley sides close to settlements. In the higher reaches, especially towards the subalpine belt, decreasing richness and $\alpha$-diversity as well as high turnover may reflect natural and human-made opening of woodland. Not all findings may be explained satisfactorily, though, and a much larger number and denser network of thorough descriptive case studies than available at present is urgently needed as reference data for the interpretation of spatial patterns and future change in plant and vegetation diversity of northern Pakistan.

\section{References}

Acharya,K.P., Vetaas,O.R., Birks,H., 2011. Orchid species richness along Himalayan elevational gradients. Journal of Biogeography 38, 1821-1833.

Ali,S.I., Qaisar,M., 2001. Flora of Pakistan (Fascicles series). Department of Botany, University of Karachi, Pakistan.

Austrheim,G., 2002. Plant diversity patterns in semi-natural grasslands along an elevational gradient in southern Norway. Plant Ecology 161, 193-205.

Bhattarai,K.R., Vetaas,O.R., 2003. Variation in plant species richness of different life forms along a subtropical elevation gradient in the Himalayas, east Nepal. Global Ecology and Biogeography 12, 327-340.

Bhattarai,K.R., Vetaas,O.R., Grytnes,J.A., 2004. Fern species richness along a central Himalayan elevational gradient, Nepal. Journal of Biogeography 31, 389-400.

Bhattarai,K.R., Vetaas,O.R., 2006. Can Rapoport's rule explain tree species richness along the Himalayan elevation gradient, Nepal? Diversity and Distributions 12, 373-378.

Breckle, Siegmar W., Dittmann, A., and Rafiqpoor, A. D.2010. Field Guide Afghanistan-Flora and Vegetation. Scientia Bonnensis - Langer Grabenweg 68 - D-53175 Bonn. 
Colwell,R., Lees,D.C., 2000. The mid-domain effect: geometric constraints on the geography of species richness. Trends in Ecology \& Evolution 15, 70-76.

Dobremez, Jean François and Jest, Corneille.1976. Manaslu: hommes et milieux des vallées du Népal central. Éditions du Centre national de la recherche scientifique.

Fosaa,A.M., 2004. Biodiversity patterns of vascular plant species in mountain vegetation in the Faroe Islands. Diversity and Distributions 10, 217-223.

Grau,O., Grytnes,J.-A., Birks,H.J.B., 2007. A comparison of altitudinal species richness patterns of bryophytes with other plant groups in Nepal, Central Himalaya. Journal of Biogeography 34, 1907-1915.

Grytnes,J.A., 2003. Species-richness patterns of vascular plants along seven altitudinal transects in Norway. Ecography 26, 291-300.

Grytnes,J.A., Beaman,J.H., 2006. Elevational species richness patterns for vascular plants on Mount Kinabalu, Borneo. Journal of Biogeography 33, 1838-1849.

Grytnes,J.A., Vetaas,O., 2002. Species Richness and Altitude: A Comparison between Null Models and Interpolated Plant Species Richness along the Himalayan Altitudinal Gradient, Nepal. The American Naturalist 159, 294-304.

Jost,L., 2006. Entropy and diversity. Oikos 113, 363-375.

Kessler,M., 2000. Elevational gradients in species richness and endemism of selected plant groups in the central Bolivian Andes. Plant Ecology 149, 181-193.

Khan,N., Ahmed,M., Wahab,M., Ajaib,M., Hussain,S.S., 2010. Studies along an altitudinal gradient in Monotheca buxifolia (Falc.) A.D, Forest, District Lower Dir, Pakistan. Pakistan Journal of Botany 42, 3029-3038.

Khan,S.M., Harper,D., Page,S., Ahmad,H., 2011. Species and Community Diversity of Vascular Flora Along Environmental Gradient in Naran Valley: A Multivariate Approach Through Indicator Species Analysis. Pakistan Journal of Botany 43, 2337-2346.

Koleff,P., Gaston,K.J., Lennon,J.J., 2003. Measuring beta diversity for presence-absence data. Journal of Animal Ecology 72, 367-382.

Körner,C., 2000. Why are there global gradients in species richness? mountains might hold the answer. Trends in Ecology \& Evolution 15, 513-514.

Legendre,P., Borcard,D., Peres-Neto,P.R., 2005. Analyzing beta diversity: partitioning the spatial variation of community composition data. Ecological Monographs 75, 435-450.

Lomolino,M.V., 2001. Elevation gradients of species-density: historical and prospective views. Global Ecology and Biogeography 10, 3-13. 
Mahdavi,P., Akhani,H., Van der Maarel,E., 2013. Species Diversity and Life-Form Patterns in Steppe Vegetation along a $3000 \mathrm{~m}$ Altitudinal Gradient in the Alborz Mountains, Iran. Folia Geobotanica 48, 7-22.

McCain,C.M., 2009. Global analysis of bird elevational diversity. Global Ecology and Biogeography 18, 346-360.

New,M., Lister,D., Hulme,M., Makin,I., 2002. A high-resolution data set of surface climate over global land areas. Climate research 21, 1-25.

O' Brien,E.M., 1993. Climatic gradients in woody plant species richness: towards an explanation based on an analysis of southern Africa's woody flora. Journal of Biogeography 20, 181-198.

Ohlemüller,R., Wilson,J.B., 2000. Vascular plant species richness along latitudinal and altitudinal gradients: a contribution from New Zealand temperate rainforests. Ecology Letters 3, 262266.

Panayiotis,T., Maria,P., Spyros,T., 2013. Elevational Gradient of Vascular Plant Species Richness and Endemism in Crete - The Effect of Post-Isolation Mountain Uplift on a Continental Island System. PLoS ONE 8.

Parris,B.S., Beaman,R.S., Beaman,J.H., 1992. The plants of Mount Kinabalu: 1. Ferns and fern allies. Kew: Royal Botanic Gardens, Kew 165p. -col. illus. . ISBN 947643354.

Pianka,E.R., 1966. Latitudinal gradients in species diversity: a review of concepts. American Naturalist 33-46.

R Core Team, 2014. R: A language and environment for statistical computing. R foundation for Statistical Computing.

Rahbek,C., 1995. The Elevational Gradient of Species Richness - A Uniform Pattern. Ecography 18, 200-205.

Rahbek,C., 2005. The role of spatial scale and the perception of large-scale species-richness patterns. Ecology Letters 8, 224-239.

Ren,H.B., Niu,S.K., Zhang,L.Y., Ma,K.P., 2006. Distribution of vascular plant species richness along an elevational gradient in the Dongling Mountains, Beijing, China. Journal of Integrative Plant Biology 48, 153-160.

Saeeda,Y., Deforestation and its impacts on livelihood opportunities in Miandam Valley Swat, Ethnobotany Project, WWF-Pakistan. 2005.

Sánchez-González,A., López-Mata,L., 2005. Plant species richness and diversity along an altitudinal gradient in the Sierra Nevada, Mexico. Diversity and Distributions 11, 567-575. 
Sanders,N.J., Rahbek,C., 2012. The patterns and causes of elevational diversity gradients. Ecography 35,1 .

Saqib,Z., Malik,R.N., Shinwari,M.I., Shinwari,Z.K., 2011. Species Richness, Ethnobotanical Species Richness and Human Settlements Along A Himalayan Altitudinal Gradient: Prioritizing Plant Conservation in Palas Valley, Pakistan. Pakistan Journal of Botany 43, $129-133$.

Schroeder, F. G.1998. Lehrbuch der Pflanzengeographie. Quelle \& Meyer verlag Wiesbaden.

Shaheen,H., Shinwari,Z.K., 2012. Phytodiversity and Endemic Richness of Karambar Lake Vegetation from Chitral, Hindukush-Himalayas. Pakistan Journal of Botany 44, 15-20.

Tichý,L., 2002. JUICE, software for vegetaion classification. Journal of Vegetation Science 13 (3), 451-453.

Tyron, R1989. Pteridophytes.Ecosystems of the World, Vol. 14B.Tropical rainforest ecosystems, biogeographical and ecological studies. Elesevier Scientific, Amsterdam..

Urrahman, M.2012. Wild plants of Swat,Pakistan. Department of Botany Government Jahanzeb Post graduate College,Saidu Sharif, Swat, Pakistan.

Vazquez,J.A., Givnish,T.J., 1998. Altitudinal gradients in tropical forest composition, structure, and diversity in the Sierra de Manantlan. Journal of Ecology 86, 999-1020.

Vetaas,O.R., Grytnes,J.-A., 2002. Distribution of vascular plant species richness and endemic richness along the Himalayan elevation gradient in Nepal. Global Ecology and Biogeography $11,291-301$.

Wallace, Alfred Russel1878. Tropical Nature: And Other Essays. Macmillan and Company.

Wang,Z., Tang,Z., Fang,J., 2007. Altitudinal patterns of seed plant richness in the Gaoligong Mountains, south-east Tibet, China. Diversity and Distributions 13, 845-854.

Xu,Y., Chen,Y., Li,W., Fu,A., Ma,X., Gui,D., Chen,Y., 2011. Distribution pattern of plant species diversity in the mountainous Region of Ili River Valley, Xinjiang. Environmental Monitoring and Assessment 177, 681-694.

Zahid,M., Rasul,G., 2011. Thermal classification of Pakistan. Atmospheric and Climate Sciences 1, 206-213. 


\section{CHAPTER 5}

\section{SYNTHESIS}

The results of the present investigation provide important insight into the vegetation pattern and local plants usage in the area of Miandam, Swat, North Pakistan. The aim was to identify species composition, vegetation zonation and plant species diversity along elevation. Ethnobotanical use of plants has also been described. This quantitative study based on multivariate analysis is the first such study for this area in the province of Khyber Pakhtunkhwa. The botanically as well as ecologically largely unexplored Miandam area was selected to add to the ongoing botanical and ecological exploration of Pakistan. Below the three major aspects of the research project are described in terms of objectives, approach, outcome, and what is deduced from the results. The summary of the three chapters is given in the context of ethnobotanical findings, phytosociological and phytogeographical aspect and measurement of species diversity.

\section{Ethnobotanical findings}

In many parts of Pakistan although use of allopathic drugs has increased multifold, plants are still used for minor ailments and in some cases even for serious diseases. In a local medicinal plants business system known as "pansara" medicinal plants are prescribed and sold by Hakeems (local traditional doctors).In the research area study was carried out to document which medicinal plant species are used by locals, which plant parts are used and what kind of habitat is largely accessed for collecting medicinal plants. Along with other areas of the Khyber Pakhtunkhwa province, Miandam harbors rich medicinal plant diversity. For the first time in any region of Pakistan, the medicinal plants of the study area are classified according to biological and distributional properties as well as ecological preference. It is essential to know where and in which habitats ethno-medicinal plants occur; as such knowledge is a prerequisite to identify vulnerable plant species susceptible to overcollecting or habitat change. In the research area medicinal plants are collected from the wild but cultivated medicinal plants are also used. Based on assessment and questioning local elders and traditional healers 106 plants were identified that are used by locals for different purposes. Out of these, 99 plant species are used for human health problems, three for livestock and four for both livestock and humans. The number of plants used for livestock in the region is probably higher but based on the information from elderly people only some of them could be ascertained in the present study. Eighty out of 106 medicinal plants are indigenous to the area while the others are cultivated 
(20) or established alien plants (6). Also among the indigenous medicinal plants the majority of species is common $(61 \%)$ or scattered $(33 \%)$ in the area, thus neither of immediate conservation concern. Only five medicinal plant species $(6 \%)$ are rare in the study area: Aconitum violaceum, Colchicum luteum, Elaeagnus umbellata, Jasminum humile and Sambucus wightiana. Sambucus and Elaeagnus are woodland shrubs of which leaves and fruits or leaves and flowers, respectively, are collected for medicinal purposes.Slightly more than 50\% (55) of the ethno-medicinal plant species encountered in the study area occur in man-influenced habitat and almost $50 \%$ (51) in semi-natural habitats. Most species occurred in different kinds of woodland, while only few occur in wetlands (4) and mountain grasslands (4). Mountain grassland medicinal plants known in the Miandam valley comprise Colchicum luteum, Corydalis stewartii, Nepeta cataria and Thymus linearis.Podophyllum hexandrum and Paeonia emodi are the two excessively harvested important medicinal plants. Medicinal plants from wild are an important source of income for local communities but, if not properly managed, overcollection may lead to the destruction of habitat and in return extinction of species. Therefore, there is a need to find ways to harvest medicinal plants sustainably from the wild and to train local collectors(Shinwari, 2010).For plant conservation and to increase the locals' income it is suggested that vulnerable woodland medicinal plants of commercial value should be cultivated in newly designed and locally administered self-government agroforestry systems. One of the concerns of the locals is availability of land for medicinal plant cultivation. In a mountainous area with less available land for cultivation the locals prefer to cultivate cash crops like wheat, maize and potato for the sustenance of their families. It is recommended to use available land partly for medicinal plants and partly for other cash crops. Thus pressure on the wild medicinal plants can be reduced. Due to the specific habitat demands of many woodland plant species better results may be obtained through well managed agroforestry systems than in ex-situ sites.

\section{Phytosociological and phytogeographical aspect}

To cover the phytosociological and phytogeographical aspect of the present project the vegetation of

Miandam was thoroughly investigated with particular focus on woodlands and shrublands. The study area was previously unexplored except partial studies on forest conservation by some authors (Adnan et al. 2006; Sher and Hussain, 2007; Latif et al. 2006) and partly by WWF (World Wide Fund) Pakistan. The aim was to report plants of the research area and quantify their abundance. The findings of the vegetation study were compared with other studies in the wider surroundings of Hindukush-Himalaya. It was also assessed that how the forest ecosystem is threatened by different 
anthropogenic activities in the research area. The vascular plant species found comprise 33 trees, 52 shrubs, 305 herbs and 11 climbers. Based on multivariate analysis twelve plant communities were established including subtropical semiarid groves of Ailanthus altissima to alpine turf of Sibbaldia cuneata with Juniperus patches. Woodland of Abies pindrow and Viburnum grandiflorum is the dominant vegetation in the area. In comparison to other studies that contributed to the knowledge of woodland types from subtropical levels to the high mountains in the Hindukush-Himalaya region, e.g. Ahmed et al. (2010), Beg and Khan (1984), Hussain et al. (1992), Hussain et al. (1995), Khan (2012), Rashid et al. (2011)and Sher and Al yemeni (2011), it is evident that the present study encompasses some aspects that are not covered by other researchers. To my knowledge for the first time information about vegetation has been georeferenced. It will help to re-visit plots and locate biodiversity hot spots. Based on extensive field observations and discussions with local dignitaries the current forest situation has been described and human impact has been appraised.Ilyas et al. (2012) assessed the vegetation structure and composition in the Qalagai hills, Swat, to pinpoint strategies for the conservation of the threatened forest ecosystems in that area. Khan et al. (2013) identified plant communities in the Western Himalayas using multivariate approaches. More such studies and phytogeographical assessment is needed to get a clear picture of the forest habitats and vegetation distribution.

\section{Measurements of species diversity}

Three different indices were used for measuring diversity among three different growth forms i.e. trees, shrubs and herbs along an elevation gradient in the mountains of Miandam.Some of the patterns of species richness found in the Miandam Mountains,e.g. total species richness of flowering plants, are similar to other studies in the Himalayas(Bhattarai and Vetaas, 2003; Vetaas and Grytnes, 2002). Some patterns of diversity like beta diversity of shrubs were unique to the area. Contrary to our findings Tang et al.(2012) found that along altitudinal gradient, $\beta$-diversity of both trees and shrubs showed non-significant trends in most mountains. Species richness of all the vascular plants was highest between 2200-2500 m. A hump-shaped relationship was found between shrub richness and elevation with maximum species richness of shrubs between 2000 and $2200 \mathrm{~m}$. For all the vascular plants alpha diversity was high in the lower zone of the elevation gradient. Beta diversity of all the growth forms was quite high along the entire gradient reflecting high species turnover. Documenting and understanding patterns in beta diversity and species turnover at different spatial scales, in different areas and for different target organisms is in many ways a challenge (Tuomisto, 
2010).Anderson et al. (2011) suggested that plurality in the concept of beta diversity (use of different indices of beta diversity)can yield important ecological insights when navigated well. By knowing the properties of the measures being used and applying more than one, the underlying ecological structures in the data generating patterns in beta diversity can be revealed. Therefore it is suggested if other indices of beta diversity are used then ecologically useful findings can be obtained for diverse forest ecosystem of Miandam.

\section{Major contributions of the present project}

* Preparation of floral list of more than 5000 plants for Pakistan by collecting data from different sources. Researchers, botanists, vegetation analysts, palynologists, ecologists and students will benefit and are benefitting to further their botanical and ecological knowledge.

* A georeferenced map was developed for different plant communities of the area. For modeling the distribution of species and analyzing the correlation of species with environment georeferencing is important. It will help in tracking plant species of interest and prioritizing conservation.

* The research area was thoroughly explored to make a botanical inventory of plants of the area.

* Different elevation belts of vegetation were defined and human impact was assessed.

* Variation in richness and diversity of herbs, shrubs and trees was statistically evaluated to see patterns of species turnover at different elevation.

* Medicinal plants usage by locals was documented with ecological and chorological characteristics of plants.

Though this project has contributed and results have been summarized above but there is always room for improvement. Therefore following recommendations are made to further the understanding of mountainous as well as forest ecosystem and their services.

\section{Recommendations}

So far plant exploration is concerned, there are many critical areas and particularly mountain valleys require extensive and continuous efforts for plant exploration. New taxa may be discovered.

* There is a need to develop liaison between universities and industries for sharing information regarding biodiversity and its conservation. Universities and industries either have minimum or negligible coordination. Different stakeholders like universities, industries and research organization if brought together can unanimously reach some conclusion regarding BAP (Biodiversity action plan) based on which future policies can be formulated. 
As herbal medicines are used in the region, therefore it is important to test efficacy and safety of the medicine. It is fine to document the existing medicinal plants knowledge but it should be furthered in terms of phytochemical screening and pharmacological testing.

* Indigenous knowledge should be confirmed on scientific footings.

* There should be sustainable use of medicinal plants. It was observed during field research that those who are involved in the medicinal plants collection are totally indifferent about loss of medicinal plants in the area because of their vested interest.

* Post-harvest losses of medicinal plants should be minimized.

* For the economic benefit of local population the people should be trained about value addition to raw material.

* For promoting medicinal plant cultivation and for biodiversity conservation government should give some incentives on a small scale to attract people towards medicinal plants cultivation which will help in minimizing pressure on natural forest ecosystem.

* Modern computer tools should be used for quantitative vegetation analyses

* One important aspect of the present quantitative analysis could be soil analysisthat can help understanding the diversity and composition of plant species in different habitats.

* Red List Categories of plants of Pakistan as per recommendation of IUCN do not exist. This matter should also be given priority.

* As vegetation types of many parts of Pakistan are far from being fully explored it is essential to investigate all different types of vegetation and their climatic and topographic features. Such phytosociological studies are essential for protecting the natural plant communities and biodiversity as well as understanding the changes experienced in the past and continuing on into the future. Vegetation studies performed so far are not sufficient for constructing a vegetation map of Pakistan.

\section{References}

Adnan,S.M., Ashiq,A.K., Latif,A., Shinwari,Z.K., 2006. Threats to the sustainability of EthnoMedicinal uses in Northern Pakistan (A Case Study of Miandam Valley, District Swat, NWFP Province, Pakistan). Lyonia 11, 91-100.

Ahmed,M., Nazim,K., Siddiqui,M.F., Wahab,M., Khan,N., Khan,M.U., Hussain,S.S., 2010. Community Description of Deodar Forests from Himalayan Range of Pakistan. Pakistan Journal of Botany 42, 3091-3102. 
Anderson,M.J., Crist,T.O., Chase,J.M., Vellend,M., Inouye,B.D., Freestone,A.L., Sanders,N.J., Cornell,H.V., Comita,L.S., Davies,K.F., 2011. Navigating the multiple meanings of $\beta$ diversity: a roadmap for the practicing ecologist. Ecology Letters 14, 19-28.

Beg,A.R., Khan,M.H., 1984. Some more plant communities and the future of dry oak forest zone in Swat valley. Pakistan Journal of Forestry 34, 25-35.

Bhattarai,K.R., Vetaas,O.R., 2003. Variation in plant species richness of different life forms along a subtropical elevation gradient in the Himalayas, east Nepal. Global Ecology and Biogeography 12, 327-340.

Hussain,F., Ilyas,M., Gil,K., 1995. Vegetation studies of Girbanr Hills District Swat, Pakistan. The Korean journal of Ecology 18, 207-218.

Hussain,F., Saljoqi,A.R., Shah,A., Ilahi,I., 1992. Phytosociology of the vanishing sub-tropical vegetation of Swat with special reference to Docut hills II: Spring aspect [Pakistan]. Sarhad Journal of Agriculture 8, 185-191.

Ilyas,M., Shinwari,Z.K., Qureshi,R., 2012. Vegetation composition and threats to the montane temperate forest ecosystem of Qalagai hills, Swat, Khyber Pakhtunkhwa, Pakistan. Pakistan Journal of Botany 44, 113-122.

Khan,N., 2012. A community analysis of Quercus baloot Griff, forest. District Dir Upper, Pakistan. African Journal of Plant Sciences 6, 21-31.

Khan,S.M., Page,S., Ahmad,H., Harper,D., 2013. Identifying plant species and communities across environmental gradients in the Western Himalayas: Method development and conservation use. Ecological Informatics 14, 99-103.

Latif,A., Shinwari,Z.K., Hussain,J., Murtaza,S., 2006. NTFPS: An alternative to forest logging in Miandam and Sultanar Valley Swat. Lyonia 11, 15-21.

Rashid,A., Swati,M.F., Sher,H., Al-Yemeni,M.N., 2011. Phytoecological evaluation with detail floristic appraisal of the vegetation around Malam Jabba, Swat, Pakistan. Asian Pacific journal of tropical biomedicine 1, 461-467.

Sher,H., Al yemeni,M.N., 2011. Economically and ecologically important plant communities in high altitude coniferous forest of Malam Jabba, Swat, Pakistan. Saudi Journal of Biological Sciences 18, 53-61.

Sher,H., Hussain,S.K., Ecological survey and rapid vulnerability assessment of medicinal and aromatic plants of Miandam,Pakistan. 2007. WWF,Pakistan.

Shinwari,Z.K., 2010. Medicinal plants research in Pakistan. Journal of medicinal plants research 4, 161-176. 
Tang,Z., Fang,J., Chi,X., Feng,J., Liu,Y., Shen,Z., Wang,X., Wang,Z., Wu,X., Zheng,C., 2012. Patterns of plant beta-diversity along elevational and latitudinal gradients in mountain forests of China. Ecography 35, 1083-1091.

Tuomisto,H., 2010. A diversity of beta diversities: straightening up a concept gone awry. Part 2. Quantifying beta diversity and related phenomena. Ecography 33, 23-45.

Vetaas,O.R., Grytnes,J.-A., 2002. Distribution of vascular plant species richness and endemic richness along the Himalayan elevation gradient in Nepal. Global Ecology and Biogeography 11, 291-301. 


\section{Declaration of originality and certificate of ownership}

I, Naveed akhtar, hereby declare that this dissertation entitled "Exploring Patterns of Phytodiversity, Ethnobotany, Plant Geography and Vegetation in the Mountains of Miandam, Swat, Northern Pakistan" is my own work and to the best of my knowledge I have documented all sources used.

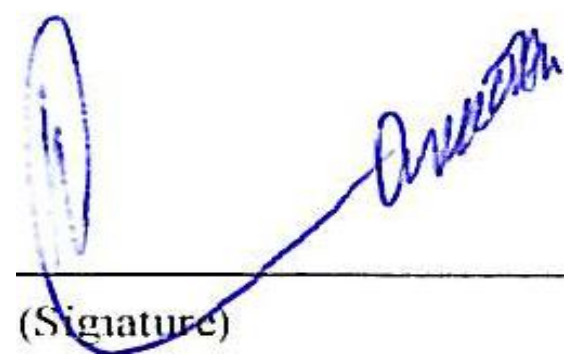

NAVEED AKHTAR

Göttingen, August $20^{\text {th }}, 2014$ 


\section{Currículum Vitae}

\section{Naveed Akhtar}

Date of birth:

$5^{\text {th }}$ March 1975

Domicile:

Qambar, District Swat, KP, Northern Pakistan

Present Address:

Department of Botany, Islamia College Peshawar, Pakistan

EMail

naveedakhter75@yahoo.com

\section{RESEARCH PUBLICATIONS}

1. Akhtar, N. and S. Z. Shah. 1999. Some studies on the blue green algae of paddy-fields of Swat. Scientific Khyber, 12 (1): 93-102.

2. Shah. S.Z., S. Ali and N. Akhtar.1999. Some observation on the algae of waterlogged and saline areas of district Nowshera, Pakistan. Scientific Khyber, 12 (1): 87-91.

3. Shah, S.Z., M. Qayyum and N. Akhtar. 1999. Phycological studies of saline \& waterlogged areas of District Swabi, NWFP, Pakistan. Scientific Khyber, 12 (2): 107114.

4. Shah, S.Z., N. Akhtar and L. Zaman. 2000. Some studies on corticulous algae of Peshawar university campus. Scientific Khyber, 13 (1): 87-96.

5. Shah, S.Z., N. Ahmad, N. Akhtar, I. Khan and S. A. Khan. 2001. Studies of ulotrichales of Peshawar District, NWFP, Pakistan. Scientific Khyber, 14 (2): 73-78.

6. Abu Nasar, Abdul Rashid, N. Akhtar and J. Shah. 2004. Taxonomic description of spiny plants of district Hangu. Scientific Khyber, 17 (1): 45-54.

7. Abu Nasar, Abdul Rashid, N. Akhtar and J. Shah. 2005. Taxonomic description of 
thorny plants of district Hangu. Scientific Khbyer, 18 (1): 31-35.

8. Murad, W., S.Z. Shah, K. Iqbal and N. Akhtar. 2005. Taxonomic study of xerophytes of district Karak. Scientific Khyber, 18 (1): 17-30.

9. Zabihullah, Abdurrashid and N. Akhtar. 2006. Ethnobotanical survey in Kot Manzaray baba valley Malakand Agency, Pakistan. Pak. J. Pl. Sci., 12 (2): 115-121.

10. Akhtar, N. and A. Syed. 2006. Epidermal structures as taxonomic feature in some members of Acanthaceae. Pak. J. Pl. Sci., 12 (2): 163-166.

11. Islam, M., H. Ahmad, Abdurrashid, Abdurrazaq, N. Akhtar and I. Khan. 2006. Weeds and medicinal plants of Shawar valley, district Swat. Pak. J. Weed Sci.Res. 12 (1-2): 8388.

12. Nisar, M. Mehbooburrahman, M. A. Khan, W. Murad, N. Akhtar and Sirajuddin. 2006. Key to identify the plants of family Rosaceae and their indigenous uses in Swat. Scientific Khyber, 19 (2): 165-171.

13. Burni, T., N. Akhtar, A. Liaqat and S.M. A. Rizvi. 2006. VAM studies in plants of aquatic habitat of Akbar pura, District Nowshera, NWFP, Pakistan. Scietific Khyber, 19 (1): 21-28.

14. Zabihullah, N. Akhtar and Abdurrashid.2007. A checklist of plants in Manzray Baba valley Malakand Agency, Pakistan. Pak. J. Pl. Sci., 13 (2) 111-117.

15. Akhtar, N. and F. Hussain. 2007. Weeds of wheat fields of village Qambar, District Swat, Pakistan. Pak. J. Pl. Sci., 13 (1): 31-35.

16. Bibi, N., M. Hussain and N. Akhtar. 2008. Palynological study of some cultivated species of Genus Hibiscus from North West Frontier Province, Pakistan. Pak. J. Bot., 40 (4): 1561-1569, 2008. 
17. Khan, S. A., L. Khan, I. Hussain, H. Shah, and N. Akhtar. 2008. Comparative assessment of heavy metals in Euphorbia helioscopia L. Pak. J. Weed Sci. Res. 14 (1-2): 91-100.

18. Khan, S. A., L. Khan, I. Hussain, K.B. Marwat and N. Akhtar. 2008. Profile of Heavy Metals in Selected Medicinal Plants. Pak. J. Weed Sci. Res. 14 (1-2): 101-110.

19. Tanvir. B., N. Akhtar, Dur-e-Afshan and S.B. Zainab. Mycorrhizal studies in plants of saline habitats of district Kohat, Pakistan. Pak. J. Pl. Sci., 14 (2): 77-83.

20. Akhtar, N., M. Ibrar and N. Aman. 2008. The effects of different soaking times and concentration of $\mathrm{GA}_{3}$ on seed germination and growth of Spinacea oleracea L. Pak. J. Pl. Sci., 14 (1): $9-13$.

21. Mohammad, Z., N. Akhtar and S. Islam. 2008. Effect of gamma irradiation on the germination and seedling growth of Lepidium sativum L. Pak. J. Pl. Sci., 14 (2): 101-106.

22. Hadi, F., N.Akhtar, S.M.Shah and F.Hussain.2008. Ecological characteristics of the plants of Warsak dam, District Peshawar, Pakistan.PUTAJ. 15:17-30.

23. Akhtar, N. and S.R. rehman.2009. Some members of ulotrichales from Jalala, District Mardan, Pakistan. Pak. J. Pl. Sci., 15 (1): 19-30.

24. Akhtar, N. and S.Begum.2009. Ethnopharmacological imprtant plants of Jalala, District Mardan, Pakistan. Pak. J. Pl. Sci., 15 (2): 95-100.

25. Badshah, L., F.Hussain and N.Akhtar.2010.vegetation structure of subtropical forest ofTabai, South Waziristan, Pakistan. Front. Agric.China 4(2):232-236.

26. Bibi,N., N. Akhtar ,M. Hussain and M.A.Khan.2010.systematic implications of pollen morphology in the family Malvaceae from North West Frontier Province, Pakistan. Pak. J. Bot., 42(4): 2205-2214. 
27. Barkatullah, N. Akhtar, M. Ibrar and A. Rauf. 2012. Effect of Drought on the Morphological and Mineral Composition of Abelmoschus esculentus. Middle-East Journal of Medicinal Plants Research 1(3): 59-62.

28. Akhtar, N., A. Rashid, W.Murad, E. Bergmeier. 2013. Diversity and use of ethnomedicinal plants in the region of Swat, North Pakistan. Journal of ethnobiology and ethnomedicine, 9(1), 25.

29. Habib-Ul-Hassan., W. Murad, N., Ahmad, A. Tariq, I. Khan, N. Akhtar, and S. Jan. (2015). Indigenous uses of the plants of Malakand valley, district Dir (Lower), Khyber Pakhtunkhwa, Pakistan. Pak. J. Weed Sci. Res, 21(1), 83-99.

30. Jan, S., I. Ahmad, N. Akhtar, A. Iqbal, S. Wali, and F. Rahim. Taxonomic diversity and folk medicinal recipes used for various ailments in Torkoh area Chitral, Pakistan. Journal of Biodiversity and Environmental Sciences, 6(3): 226-237

\section{TRAININGS AND WORKSHOPS ATTENDED:}

1. Training Course in Latest Developments in Molecular Biology and Biotechnology at UGC Regional Centre, Lahore, Oct.8-13, 2001.

2. Staff Development Course under the Scheme NAHE at University of Peshawar, Dec. $1^{\text {st }}-31^{\text {st }}$, 2005

3. Training Course in Biodiversity and Weed Science at Department Of Weed Science, NWFP Agricultural University, Peshawar, Dec. 11-16, 2006

4. Workshop on Training of Trainers in Conservation Strategies for Plant Biodiversity of Pakistan at University of Peshawar, August 20-21, 2007 
5. Training Course on Utilization of DNA Technology in Plant Improvement at University Of Hazara, May 22-26, 2007

6. HEC Workshop on Identification of Flowering Plants and Herbarium Techniques at University Of Sindh Jamshoro, March $24^{\text {th }}-25^{\text {th }}, 2008$

7. $35^{\text {th }}$ All Pakistan Science Conference at ICCBS/LEJ University of Karachi, Karachi, Dec. 20-23, 2008

8. Workshop on Effective Professional Communication at Staff Training Institute, University of Peshawar, January 18-22, 2010

9. International Seminar on Natural Disaster and Sustainable Development in Göttingen, Germany, $17^{\text {th }}-18^{\text {th }}$ April, 2013. 